\title{
Smernice za vrednotenje izvajalcev gozdarskih storitev - strokovna ocena MojGozdar
}


Založnik: Gozdarski inštitut Slovenije, založba Silva Slovenica, Ljubljana 2019

Naslov: Smernice za vrednotenje izvajalcev gozdarskih storitev - strokovna ocena ocena MojGozdar

Avtorji: Matevž Triplat, Mirko Baša, Nina Škrk;

Lektura: Henrik Ciglič;

Recenzent: Darij Krajčič;

Cena: brezplačno

Izdaja: elektronska izdaja (pdf)

Elektronski izvod: https://www.mojgozdar.si/

DOI 10.20315/SilvaSlovenica.0016

Kataložni zapis o publikaciji (CIP) pripravili v Narodni in univerzitetni knjižnici v Ljubljani

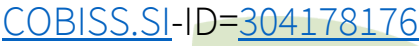

ISBN 978-961-6993-52-4 (pdf)

Ljubljana, 30. September 2019

Spletni informacijski sistem MojGozdar smo razvili v okviru cilno raziskovalnega programa "Zagotovimo si hrano za jutri", v sklopu raziskovalnega projekta Sistem ocenjevanja kakovosti izvajalcev del v gozdarstvu (Št. projekta: V4 1615), ki ga financirata Ministrstvo za kmetijstvo, gozdarstvo in prehrano ter Agencija RS za raziskovalno dejavnost. 
KAZALO

1 Uvod

2 Seznam načel, kriterijev in indikatorjev za ocenjevanje poslovnih subjektov ......................... 6

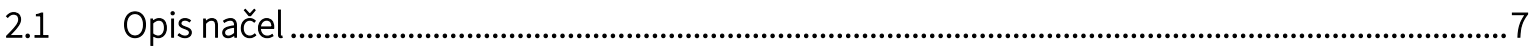

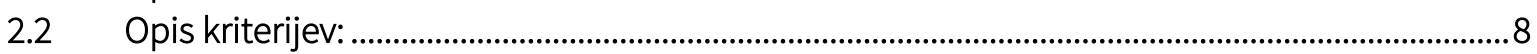

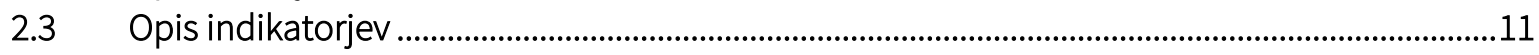

Preglednica 5: Indikatorji vrednotenja neodvisna strokovni oceni .....................................................11

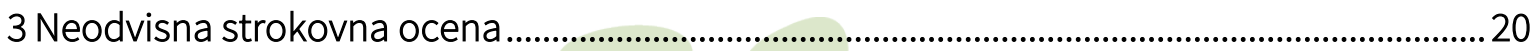

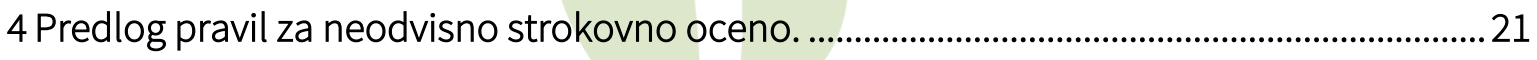

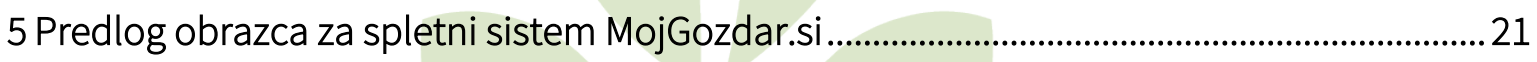

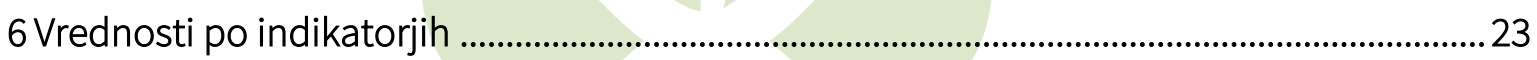

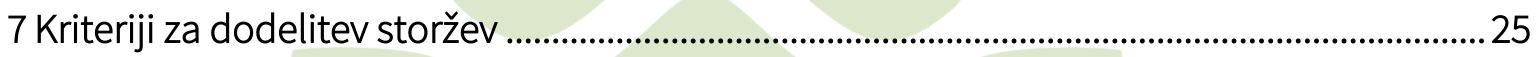

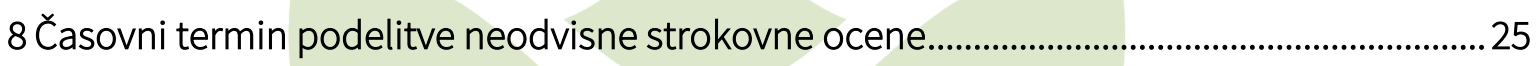

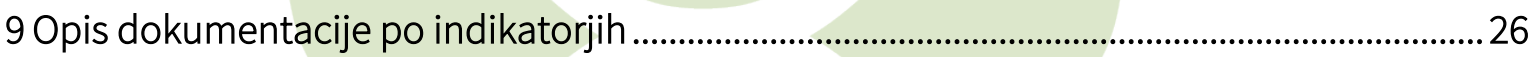

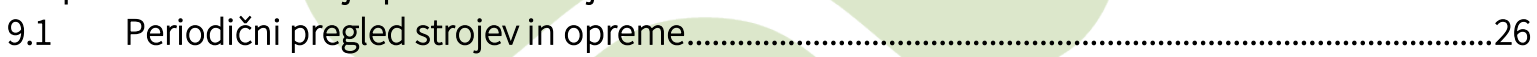

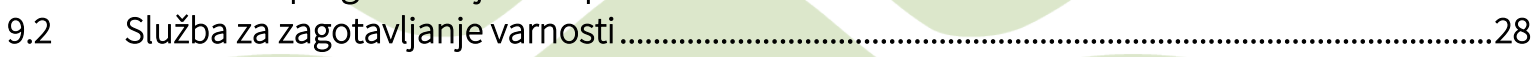

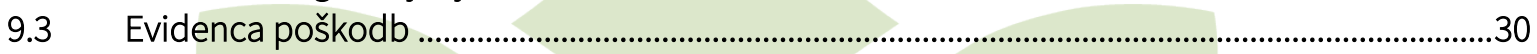

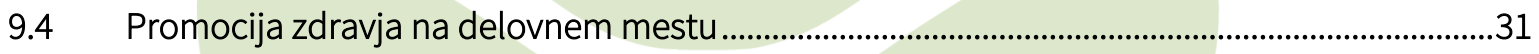

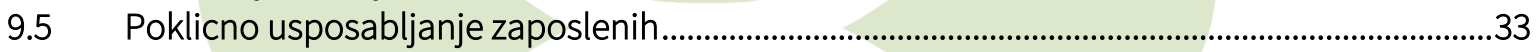

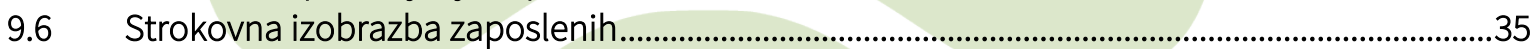

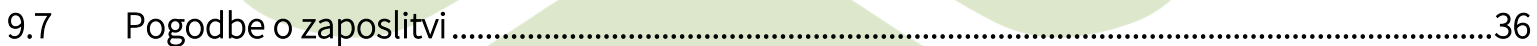

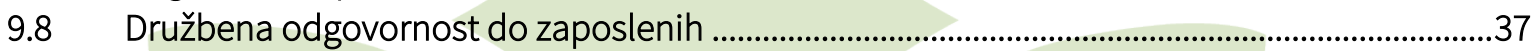

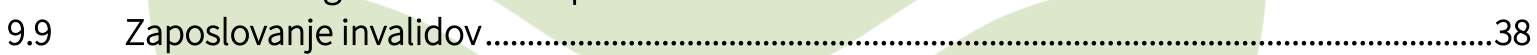

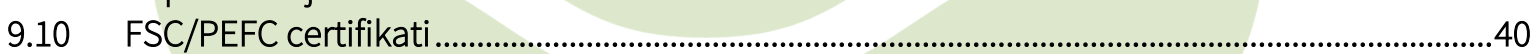

9.11 Varovanje sestoja, gozdnih tal, vodotokov in infrastrukture ...................................................4

9.12 Zmanjšanje emisij škodljivih snovi v izpušnih plinih pri strojih...................................................45

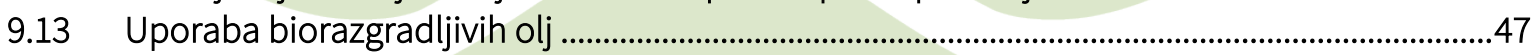

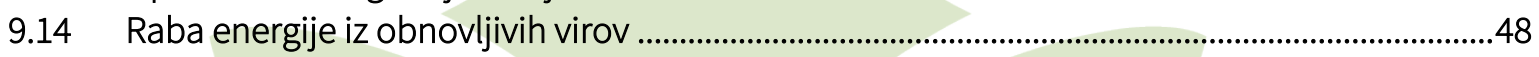

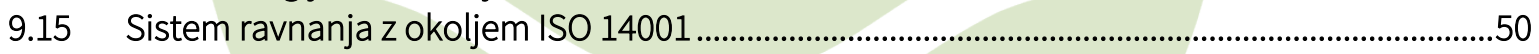

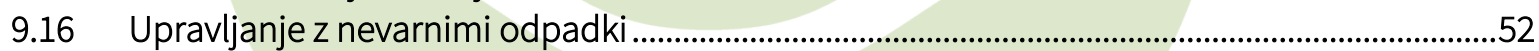

9.17 Skladnost z okoljskimi omejitvami in zahtevami ......................................................................55

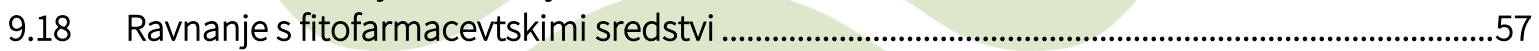

9.19 Sodelovanje ali finančna podpora v lokalnih projektih ...........................................................59

9.20 Članstvo v interesnih združenjih ..........................................................................................6

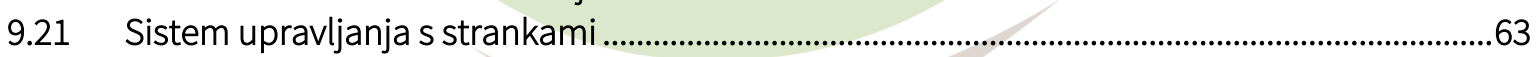

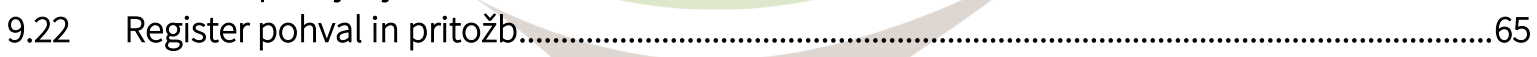

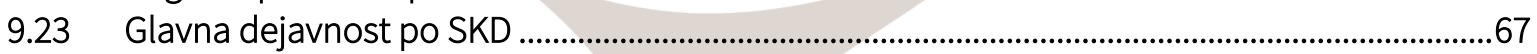

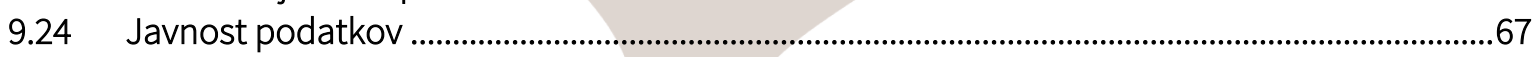

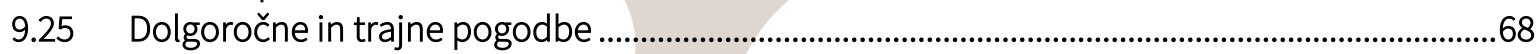

9.26 Pokrivanje več vmesnih procesov (lastna primarna predelava itd.) ............................................69

9.27 Naložbe v osnovna sredstva ....................................................................................................... 71

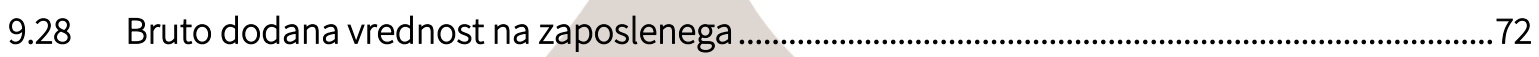

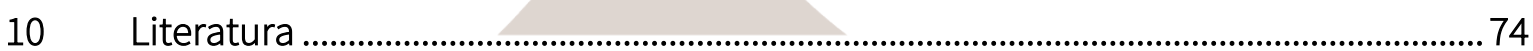

Gozdarski inštitut Slovenije 


\section{SEZNAM UPORABLJENIH KRATIC}

AJPES Agencija Republike Slovenije za javnopravne evidence in storitve

AHP Analytic Hierarchy Process

CRM Customer Relationship Management

ESA Evropski sistem računov ("European system of accounts«)

FFS Fitofarmacevtska sredstva

FURS Finančna uprava Republike Slovenije

FSC Forest Stewardship Council

GIS Gozdarski inštitut Slovenije

IKGLR Inšpektorat Republike Slovenije za kmetijstvo, gozdarstvo, lovstvo in ribištvo

ISO International Organization for Standardization

KGZS Kmetijsko gozdarska zbornica Slovenije

OVE Obnovljivi viri energije

PEFC Programme for the Endorsement of Forest Certification

PRS

Poslovni register Slovenije

SKD

Standardna klasifikacija dejavnosti

ZGS

Zavod za gozdove Slovenije 


\section{Uvod}

$\checkmark$ zadnjih letih beležimo izrazito povečanje števila ponudnikov del $\vee$ gozdarstvu ( $v$ nadaljevanju ponudniki), kar pomeni večjo konkurenco na trgu, a hkrati terja tudi razmislek o objektivni presoji kakovosti ponudnikov. Celostnega sistema objektivne presoje kakovosti ponudnikov v Sloveniji nimamo. Pri trajnostnem gospodarjenju z gozdovi veliko število ponudnikov ne sme biti edino gonilo za povečevanje konkurenčnosti sektorja. V tujini pa tudi pri nas ima merilo najnižje cene storitev vse pogosteje opraviti z vprašanji kakovosti izvedbe del, pri čemer pa se med merila kakovosti uvrščajo tako okoljski, socialni kot tudi poslovni vidiki odnosa med naročnikom in izvajalcem del.

Naš cilj je razviti enostaven, pregleden in objektiven postopek za presojo ustreznosti ponudnikov, ki v Sloveniji opravljajo eno ali več faz gozdarskih del.

Metodologija za ocenjevanje ponudnikov je sestavljena iz treh delov, in sicer iz:

1) Ocene formalne ustreznosti izvajalca gozdarskih del na podlagi osnovnih (primarnih) virov podatkov o poslovnih subjektih.

2) Strokovne ocene MojGozdar ustreznosti poslovnega subjekta za opravljanje določenih gozdarskih del, po principu kategorizacije nastanitvenih obratov (s kategorijami/zvezdicami). Strokovna ocena MojGozdar se podeli upravičencem na podlagi sklenjene pogodbe o sodelovanju in strokovne presoje. Upravičenec, ki izpolnjuje zahteve strokovne ocene, pridobi pravico do uporabe znaka MojGozdar (od 1 do 5 storžev) za obdobje treh let.

3) Neposrednega rangiranja kakovosti opravljenih storitev s strani naročnikov. Povprečni rang, pridobljen s strani uporabnikov storitev, je objavljen poleg pridobljenih kategorij (prvotne kombinirane ocene) ponudnika. Range lahko pridobijo vsi ponudniki, ki so vključeni v sistem pridobitve strokovne ocene, za kar je pripravljen poseben vprašalnik za naročnike konkretnih storitev. Za zagotavljanje verodostojnosti ocenjevalca določenega izvajalca bomo vzpostavili mehanizme za preprečevanje zlorab spletnega informacijskega sistema.

Vsi ponudniki in njim pripadajoče ocene so objavljeni na spletnem informacijskem sistemu www.mojgozdar.si, ki je osrednji sistem iskanja ponudnikov oziroma omogoča aktivno povezovanje lastnika gozda (iskalca storitve - povpraševanje) s ponudnikom storitve. Vse predstavljene aktivnosti so del CRP-projekta: Sistem ocenjevanja kakovosti del v gozdarstvu, ki ga financirata MKGP in ARRS. 


\section{Načela, kriteriji in indikatorji strokovne ocene MojGozdar}

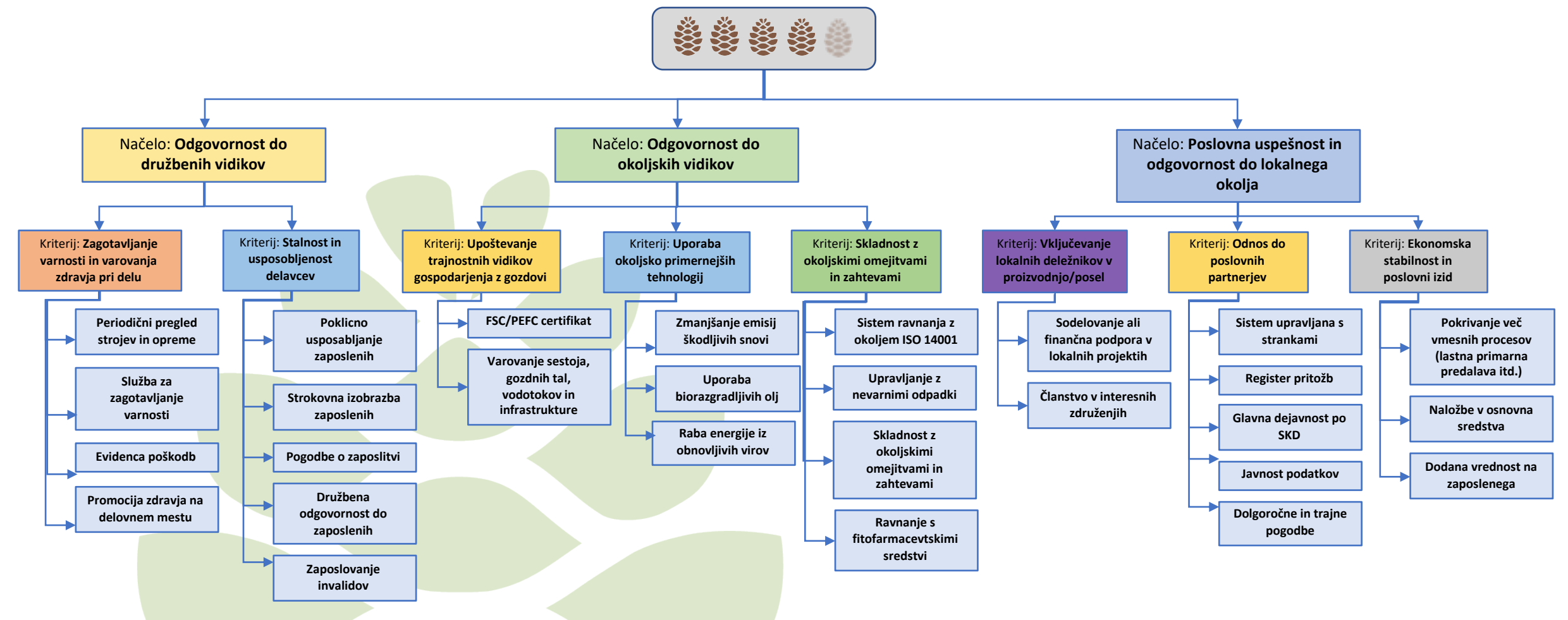

Slika 1: Shematski prikaz načel, kriterijev in indikatorjev sistema strokovne ocene MojGozdar.si

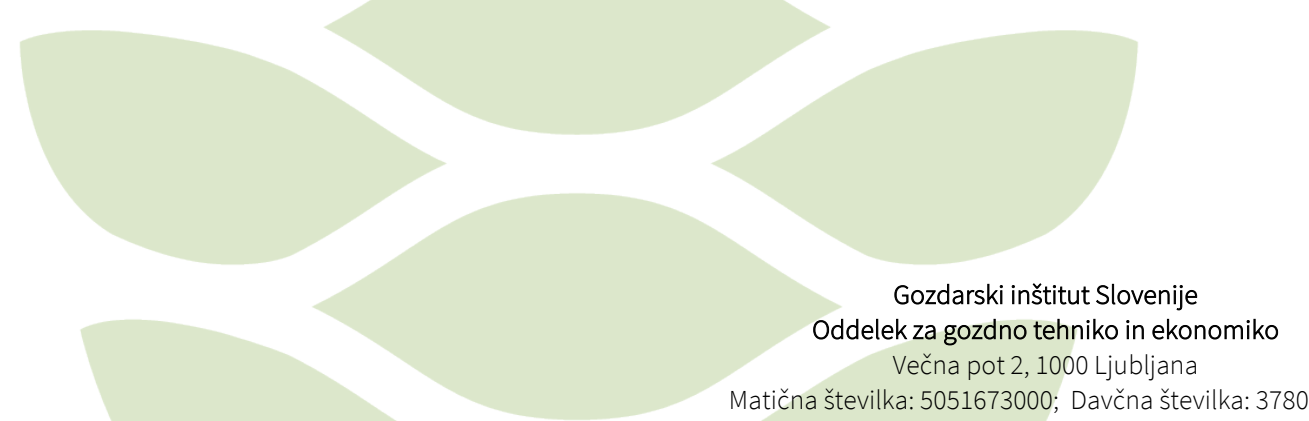




\section{Moj Gozdar}

\subsection{Opis načel}

Glavno načelo strokovne ocene MojGozdar je izpolnjevanje meril trajnostnega gospodarjenja z gozdovi z doseganjem nadstandarda pri družbenih, ekonomskih in okoljskih vidikih izvedbe del (slika 1). "Uradno" definicijo trajnostnega gospodarjenja gozdov so določili v sklopu ministrske konference o varstvu gozdov v Evropi, ki je trajnostno gospodarjenje z gozdovi opredelila kot:

Trajnostno gospodarjenje pomeni upravljanje in rabo gozdov in gozdnih površin na način in po obsegu, ki ohranja raznovrstnost, produktivnost, regeneracijsko sposobnost, vitalnost kot tudi njegovo sposobnost, da sedaj in v prihodnosti izpolnjuje ekološke, ekonomske in socialne funkcije na lokalni, nacionalni in globalni ravni, ne da bi pri tem ogrožal druge ekosisteme.

Trajnostno gospodarjenje se uporablja v pomeni izboljšati kakovost izvedbe in kakovost življenja ob upoštevanju okoljske omejitve. Gre za možnost ponudnikov gozdarskih storitev, da $v$ svoje poslovne modele vpeljejo družbeno odgovorno ravnanje in s tem prispevajo $k$ celotni družbi.

\section{Družbeno načelo}

Družbeno načelo trajnostnega gospodarjenja zajema odgovornost do družbe na področju pravic delavcev, varnosti delavcev, zdravstvene varnosti, zaposlovanja invalidov in osebnega razvoja zaposlenih. Najpogosteje je družbena odgovornost podjetij na ravni EU definirana kot koncept, znotraj katerega podjetja na prostovoljni ravni vključujejo skrb za družbo in okolje v svoje vsakodnevno poslovanje in v svoja razmerja z deležniki (EKVILIB, 2019.

\section{Okoljsko načelo}

Podjetje s svojimi dejanji vpliva tako na organizacijo in zaposlene, kot tudi na okolje, zato je zelo pomembno, kako ravnamo z okoljem. Pri tem je treba izpolnjevati zahteve okoljskih zakonodaj in regulativ, upoštevati okoljske vidike in dosegati cilje v smislu napredovanja pri varstvu okolja (Knez-Riedl, 2006). Okoljsko načelo zajema odgovornost podjetja do okolja na področju trajnostnih vidikov gospodarjenja z gozdovi, spodbujanja okoljsko prijaznejših tehnologij in spoštovanja okoljskih omejitev.

\section{Ekonomsko načelo}

Ekonomske aktivnosti, produkcijski in potrošniški vzorci vedenja ter stopnja gospodarske razvitosti držav vplivajo na stanje okolja, ker so naravni viri eden izmed ključnih faktorjev v produkcijskih procesih. Vse gospodarske aktivnosti bi morale prispevati k uveljavitvi trajnostnega razvoja tako, da se pri sprejemanju odločitev upošteva, da bodo le-te ekonomsko učinkovite, družbeno pravične ter okolju prijazne (Lukić, 2004). Ekonomsko 
načelo zajema presojo poslovne uspešnosti in odgovornosti do lokalnega okolja na področju ekonomske stabilnosti in poslovnih izidov, odnosov do poslovnih partnerjev in vključevanja lokalnih deležnikov v proizvodnjo.

Pri oblikovanju metode bo vodilo neodvisnost ocen, načelo enakosti in upoštevanje meril, ki so ključna za kakovostno izvedbo del v gozdovih in uporabniku storitev lahko pomagajo pri končni izbiri izvajalca (Triplat in sod. 2018).

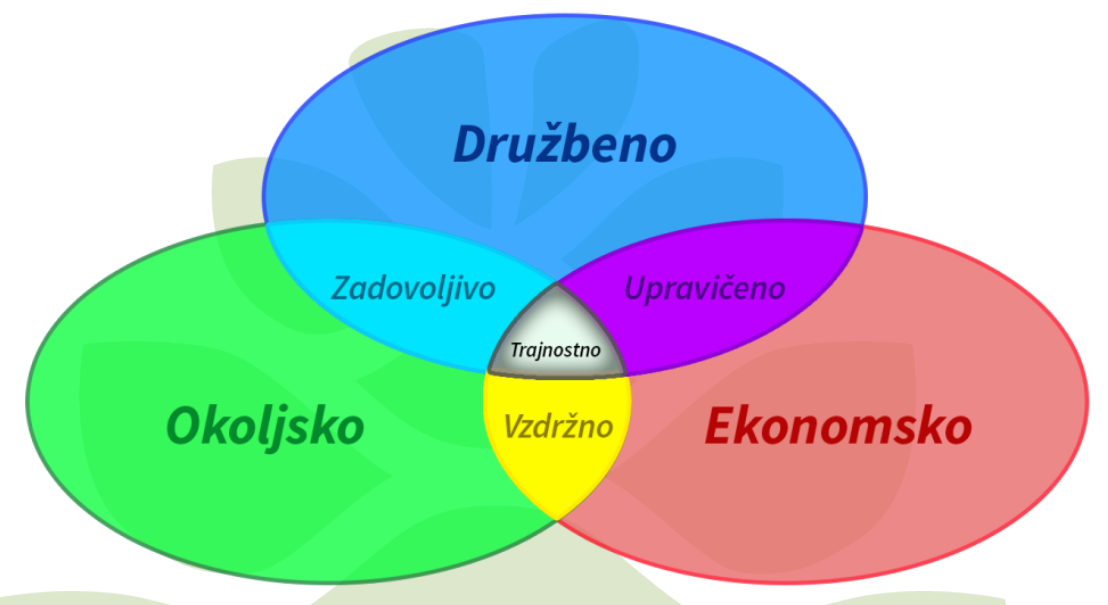

Slika 1: Načela trajnosti so glavna vodila pri razvoju metodologije za podeljevanje strokovne ocene MojGozdar.

\subsection{Opis kriterijev:}

\section{Zagotavljanje varnosti in varovanja zdravja pri delu}

Pogoji dela v gozdarstvu in lesno-predelovalnih obratih so zelo pomemben del gozdnolesnih proizvodnih verig. $V$ Sloveniji obstajajo številni predpisi glede zdravja in varnosti pri delu ter tudi glede varnosti in zdravja pri uporabi delovne opreme in strojev. Pravilna uporaba varovalne opreme in strojev je bistven kriterij za preprečevanje nezgod pri delu v gozdarski in lesno-predelovalni panogi ter ustvarja stalno konkurenco med gozdarskimi podjetji. Sistemski pristop poslovnega subjekta in nadgradnja na področju preventivnih aktivnosti s področja varovanja zdravja in varnosti pri delu se kaže tudi v ukrepih, povezanih z načrtovanjem reševalne verige na delovišču, promocijo zdravja med delovnim časom, usposobljenostjo dajanja prve pomoči in drugih aktivnostih.

\section{Stalnost in usposoblienost delavcev}

V vsaki fazi gozdno-lesne proizvodne verige morajo imeti zaposleni v gozdarskih podjetjih v skladu z veljavnimi zakoni pogodbo o zaposlitvi za opravljanje vseh dejavnosti (od sečnje v gozdu do izdelave proizvodov). Poleg tega morajo vsi posamezniki, ki so vključeni v gozdnolesno proizvodno verigo, dokazati ustrezno raven usposobljenosti glede na njihovo vlogo v 
tej verigi. Izobražen in usposobljen kader je temeljni dejavnik razvoja, kakovosti, konkurenčnosti in uspešnosti

\section{III. $\quad$ Upoštevanje trajnostnih vidikov gospodarjenja z gozdovi}

Zagotavljanje sledljivosti lesa omogoča preglednost v celotni proizvodni verigi. Poleg tega potrošniki v vse večjem številu iščejo dokaz za okolju neškodljive proizvodne postopke in zahtevajo zagotovila in dokaz od predelovalne industrije, da les in surovina, ki jo uporabljajo, prihaja iz stalno nadzorovanih virov. Evropski parlament in Svet sta oktobra 2010 sprejela Uredbo o določitvi obveznosti gospodarskih subjektov, ki dajejo na trg les in lesne proizvode (EU št. 995/2010), in je stopila v veljavo 3. marca 2013. Od takrat dalje morajo vsi proizvajalci, ki dajo na EU-trg lesne proizvode, dokazati zakonitost izvora lesnih sortimentov.

Certifikata FSC in PEFC zagotavljata, da proizvodi prihajajo iz gozdov, s katerimi se upravlja v skladu z mednarodno določenimi standardi za trajnostno gospodarjenje. Prav tako pa sledljivost materialov vzdolž proizvodne verige zagotavljata tehnična standarda EN 14961 (specifikacije goriv in razredi) in EN 15234 (zagotavljanje kakovosti goriv). Upoštevata parametre lastnosti proizvoda (npr. vsebnost vode, velikost delcev, vsebnost pepela ...).

\section{Uporaba okoljsko primernejših tehnologij}

Pri delu v gozdu gozdarska mehanizacija s svojim obratovanjem izloča številne škodljive snovi v okolje. Z uporabo tehnoloških izboljšav jih je mogoče zmanjšati ter povečati učinkovitost izrabe goriva. Vzdrževanje količine emisij, ki nastajajo vzdolž celotne proizvodne verige (tj. od poseka $v$ gozdu do prodaje končnih izdelkov), pod določenimi mejnimi vrednostmi prispeva k zmanjšanju globalnega segrevanja in onesnaženju zraka.

\section{Skladnostz okoljskimi omejitvami in zahtevami}

Skladnost z okoljskimi predpisi zagotavlja ustrezno raven varstva okolja, istočasno pa prispeva k spodbujanju zakonitosti in preglednosti vzdolž celotne gozdno-lesne verige. Ukrepi za zmanjševanje invazivnosti tehnologij pridobivanja lesa so odsev sistemskega pristopa poslovnega subjekta. Tak pristop pomeni nadgradnjo predpisov s področja varstva gozdov in izvajanja del in vpliva na kakovost opravljenih del z vidika poškodb sestoja, tal in gozdne infrastrukture ter znižuje stroške sanacije in vzdrževanja.

Aktivna vloga različnih lokalnih deležnikov znotraj gozdno lesne proizvodne verige lahko spodbudi koristno izmenjavo strokovnega znanja ter spretnosti in daje možnost za ustvarjanje delovnih priložnosti na lokalni ravni. Poleg tega z vključevanjem različnih akterjev v verigo omogočimo, da so le-ti informirani glede upravljanja proizvodne verige ter po potrebi pri upravljanju tudi aktivno sodelujejo. Nazadnje, razvoj novih projektov glede potencialne oskrbe z naravnimi viri na določenem območju omogoča oživitev lokalnega gospodarstva. 
Korekten odnos do poslovnih partnerjev je pomemben dejavnik uspeha. Dobri odnosi so namreč osnova za obojestransko koristno in dolgoročno poslovno sodelovanje. Podjetja lahko vodijo registre pohval in pritožb, s katerimi pridobijo koristne informacije za izboljšave. Velik pomen imajo tudi dolgoročne in trajne pogodbe. Dolgoročne pogodbe o dobavi surovine tako zagotavljajo ekonomsko stabilnost v proizvodni verigi. Dolgoročna pogodba prav tako omogoča zagotovitev kakovosti dobave, prednost pa je tudi prenašanje dobre prakse.

\section{Ekonomska stabilnost in poslovni izid}

Ekonomska stabilnost podjetja zagotavlja večjo učinkovitost, uspešnost in ekonomičnost poslovanja. Dolgoročna ekonomska urejenost podjetja omogoča večje zaupanje naročnikov. 


\subsection{Opis indikatorjev}

Preglednica 1: Indikatorji vrednotenja neodvisna strokovni oceni

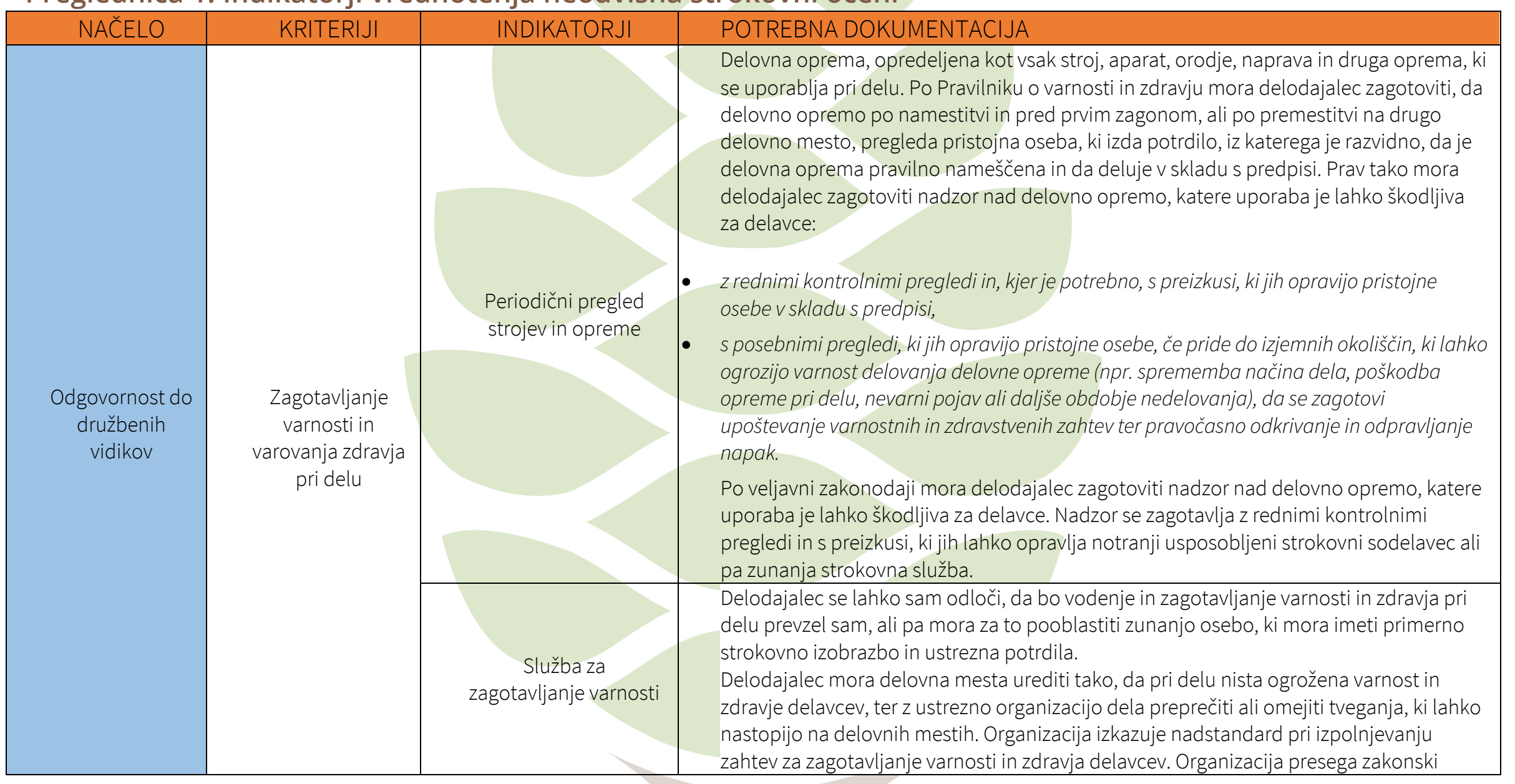

Gozdarski inštitut Slovenije 

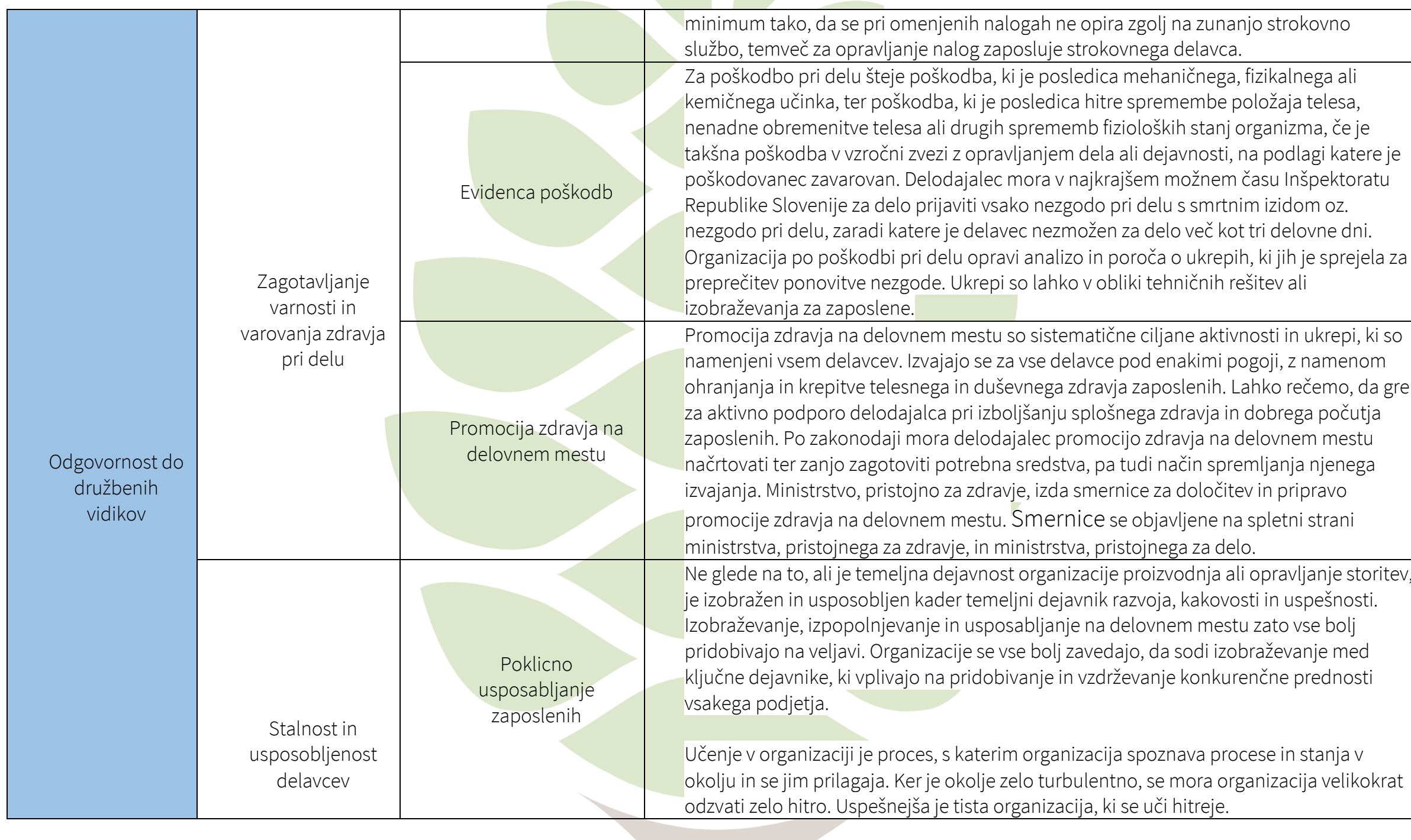

Gozdarski inštitut Slovenije

Oddelek za gozdno tehniko in ekonomiko

Večna pot 2, 1000 Ljubljana

Matična številka: 5051673000; Davčna številka: 37808052 

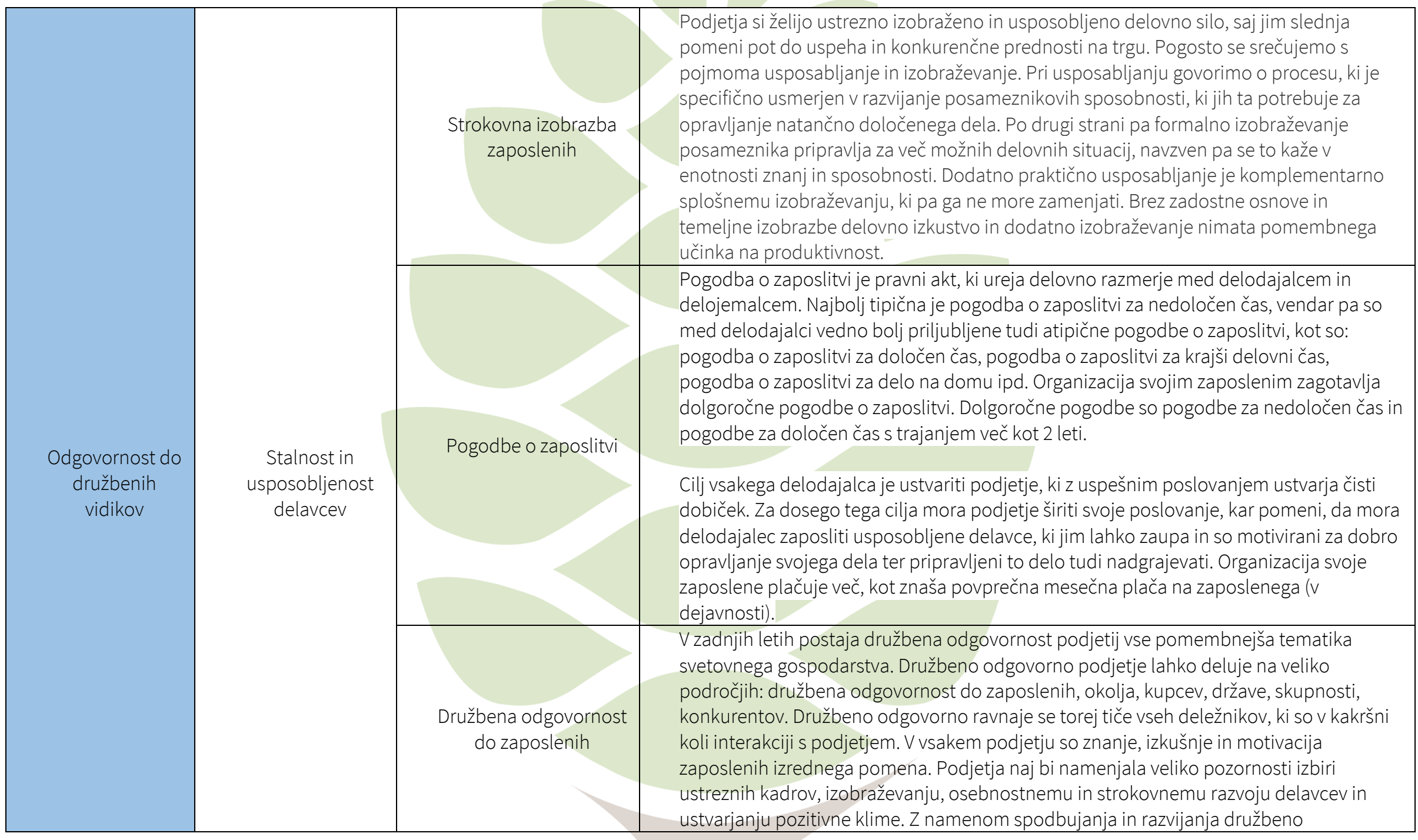

Gozdarski inštitut Slovenije

Oddelek za gozdno tehniko in ekonomiko

Večna pot 2, 1000 Ljubljana

Matična številka: 5051673000; Davčna številka: 37808052 


\begin{tabular}{|c|c|c|c|}
\hline \multirow{4}{*}{$\begin{array}{l}\text { Odgovornost do } \\
\text { okoljskih vidikov }\end{array}$} & \multirow{2}{*}{$\begin{array}{l}\text { Uporaba okoljsko } \\
\text { primernejših } \\
\text { tehnologij }\end{array}$} & $\begin{array}{c}\text { Uporaba } \\
\text { biorazgradljivih olj }\end{array}$ & $\begin{array}{l}\text { Mineralna maziva so težko razgradljiva in strupena, onesnaževanje z mazili pa vodi v } \\
\text { resne ekološke probleme. Sistem, kjer odpadnih maziv ni mogoče ponovno zbrati, } \\
\text { lahko opredelimo tudi kot sistem s popolnimi izgubami. V gozdarstvu se s to } \\
\text { problematiko srečujemo pri delu v gozdu z verižno žago in razlitjih hidravličnih olj, kjer } \\
\text { maziva končajo direktno v okolju. Tako je biološko razgradljiva olja smiselno uporabiti } \\
\text { na področjih, kjer odpadnih maziv ni mogoče zbrati in ponovno uporabiti. Prav tako je } \\
\text { uporaba okolju prilagojenih maziv smiselna tam, kjer obstaja velika možnost } \\
\text { nenamernega razlitja olja in posledično onesnaženje okolja. }\end{array}$ \\
\hline & & & $\begin{array}{l}\text { Obnovljivi viri energije postajajo zaradi vse večje odvisnosti od energije in po drugi } \\
\text { strani zmanjševanju zalog fosilnih goriv in povečanju onesnaženosti okolja vse bolj } \\
\text { pomembni. Trajnostno naravnana podjetja, ki jim je ekološko odgovorno vedenje } \\
\text { pomemben dejavnik pri izbiri vira proizvodnje električne energije, imajo sklenjeno } \\
\text { pogodbo s ponudnikom, ki zagotavlja zeleno energijo. Izraz zelena elektrika } \\
\text { uporabljamo za električno energijo, proizvedeno iz obnovljivih virov energije, ki imajo } \\
\text { manj nezaželenih vplivov na okolje kot tradicionalni neobnovljivi viri. Načelu } \\
\text { odgovornosti do okoljskih vidikov sledijo podjetja, ki imajo za svoje potrebe } \\
\text { zagotovljeno samooskrbo z električno energijo. Samoproizvajalci elektrike so torej } \\
\text { podjetja, ki poleg svoje osnovne dejavnosti proizvajajo še električno energijo ali } \\
\text { toplotno energijo v celoti ali delno za lastne potrebe. }\end{array}$ \\
\hline & \multirow{2}{*}{$\begin{array}{l}\text { Skladnost z } \\
\text { okoljskimi } \\
\text { omejitvami in } \\
\text { zahtevami }\end{array}$} & $\begin{array}{l}\text { Sistem ravna } \\
\text { okoljem ISO }\end{array}$ & $\begin{array}{l}\text { Standard, ki določa zahteve za sistem ravnanja z okoljem za proizvodne ali storitvene } \\
\text { dejavnosti, je ISO 14001. Namenjen je podjetjem, ki želijo vpeljati, ohranjati ali izboljšati } \\
\text { sistem ravnanja z okoljem, poslovati v skladu s svojo okoljsko politiko, pridobiti } \\
\text { certifikat od ustrezne organizacije in uskladiti sistem ravnanja z okoljem zahtevam } \\
\text { standarda. Nanaša se na tiste prepoznane okoljske vidike, na katere ima organizacija } \\
\text { vpliv in jih lahko obvladuje. Obsega izpolnjevanje zakonskih zahtev, učinkovito } \\
\text { izkoriščanje virov ter preprečevanje onesnaževanja okolja. }\end{array}$ \\
\hline & & $\begin{array}{c}\text { Upravljanje z } \\
\text { nevarnimi odpadk }\end{array}$ & $\begin{array}{l}\text { Pri gospodarjenju z gozdom nastajajo odpadki. Gre predvsem za odpadna olja, baterije } \\
\text { in akumulatorje, pnevmatike, odpadno embalažo ter električno in elektronsko opremo. } \\
\text { Z njimi je treba ravnati tako, da ni ogroženo človekovo zdravje in se ne povzroča škoda } \\
\text { okolju. Prepovedano jih je puščati v okolju, jih odmetavati ali z njimi nenadzorovano } \\
\text { ravnati. }\end{array}$ \\
\hline
\end{tabular}

Gozdarski inštitut Slovenije

Oddelek za gozdno tehniko in ekonomiko

Večna pot 2, 1000 Ljubljana

Matična številka: 5051673000; Davčna številka: 37808052 


\begin{tabular}{|c|c|c|c|}
\hline \multirow{3}{*}{$\begin{array}{l}\text { Odgovornost do } \\
\text { okoljskih vidikov }\end{array}$} & \multirow{3}{*}{$\begin{array}{l}\text { Skladnost z } \\
\text { okoljskimi } \\
\text { omejitvami in } \\
\text { zahtevami }\end{array}$} & & $\begin{array}{l}\text { To področje v Sloveniji urejajo Zakon o varstvu okolja, Uredba o odpadkih in drugi } \\
\text { veljavni predpisi (MOP), ki določajo pravila ravnanja in druge pogoje za preprečevanje } \\
\text { ali zmanjševanje škodljivih vplivov nastajanja odpadkov in ravnanja z njimi ter } \\
\text { zmanjševanje celotnega vpliva uporabe naravnih virov in izboljšanje učinkovitosti } \\
\text { uporabe naravnih virov. Zahteve glede ravnanja z odpadki postavljata tudi certifikata } \\
\text { FSC in PEFC. }\end{array}$ \\
\hline & & $\begin{array}{r}\text { Skladnost z okol } \\
\text { omejitvami } \\
\text { zahtevami }\end{array}$ & $\begin{array}{l}\text { Pri gospodarjenju z gozdovi naj bi se negativni vplivi na okolje odpravili oz. zmanjšali, } \\
\text { zagotavljalo naj bi se ohranjanje biotskega ravnovesja in obenem ekonomsko učinkoviti } \\
\text { načini gospodarjenja z naravnimi viri. Zakon o varstvu okolja določa, da je poseg v } \\
\text { okolje dopusten le, če ne povzroča čezmerne obremenitve. Pomembno je, da vsa } \\
\text { orodja, stroji in nevarne kemikalije, ki se uporabljajo v gozdarstvu, ustrezajo varnostnim } \\
\text { in zdravstvenim zahtevam, kot to zahtevajo mednarodni in nacionalni standardi in } \\
\text { priporočila. Z njimi lahko delajo le delavci, ki so za tako delo usposobljeni in/ali imajo } \\
\text { potrebne certifikate. }\end{array}$ \\
\hline & & $\begin{array}{r}\text { Ravnanje } \\
\text { fitofarmacev } \\
\text { sredstv }\end{array}$ & $\begin{array}{l}\text { Uporaba kemičnih sredstev v gozdu je prepovedana. Zavod za gozdove Slovenije lahko } \\
\text { izjemoma, če za to ni alternativnih gozdnogojitvenih ali drugih bioloških ukrepov, izda } \\
\text { dovoljenje za uporabo fitofarmacevtskih sredstev (v nadaljevanju FFS), ki so registrirana } \\
\text { v skladu s predpisi, ki urejajo FFS, v primerih: izkoreninjenja tujerodnih škodljivih } \\
\text { organizmov; zatiranja prenamnoženih škodljivih organizmov; zaščite gozdnega mladja } \\
\text { pred divjadjo. } \\
\text { Osnovno načelo pravilne uporabe fitofarmacevtskih sredstev je, da vedno uporabljamo } \\
\text { le v Sloveniji registrirana sredstva in to zgolj za namene in na način, za katere je uporaba } \\
\text { dovoljena. FFS v gozdu je dovoljeno uporabljati le v koncentracijah ter s pripravami in } \\
\text { na način, kot jih predpiše proizvajalec. }\end{array}$ \\
\hline $\begin{array}{c}\text { Poslovna } \\
\text { uspešnost in } \\
\text { odgovornost do } \\
\text { lokalnega okolja }\end{array}$ & $\begin{array}{c}\text { Vključevanje } \\
\text { lokalnih } \\
\text { deležnikov v } \\
\text { proizvodnjo/posel }\end{array}$ & $\begin{array}{c}\text { Sodelovanje ali } \\
\text { finančna podpora v } \\
\text { lokalnih projektih }\end{array}$ & $\begin{array}{l}\text { Podjetja svojo družbeno odgovornost in naravnanost udejanjajo skozi svojo družbeno } \\
\text { odgovorno orientiranost in ravnanje, ali pa skozi projekte na različnih področjih. } \\
\text { Pomembna je aktivnost podjetij, da podprejo in se zavzamejo za pomembne tematike v } \\
\text { družbi in s tem izpolnjujejo svojo zavezo družbene odgovornosti. Podjetja lahko pomoč } \\
\text { lokalni skupnosti izkažejo na različne načine in tako ustvarjajo pozitivne učinke med } \\
\text { lokalnim prebivalstvom. } \\
\text { Organizacija lahko izkazuje pomoč lokalni skupnosti v različnih oblikah, kot na primer: }\end{array}$ \\
\hline
\end{tabular}

Gozdarski inštitut Slovenije

Oddelek za gozdno tehniko in ekonomiko

Večna pot 2, 1000 Ljubljana

Matična številka: 5051673000; Davčna številka: 37808052 


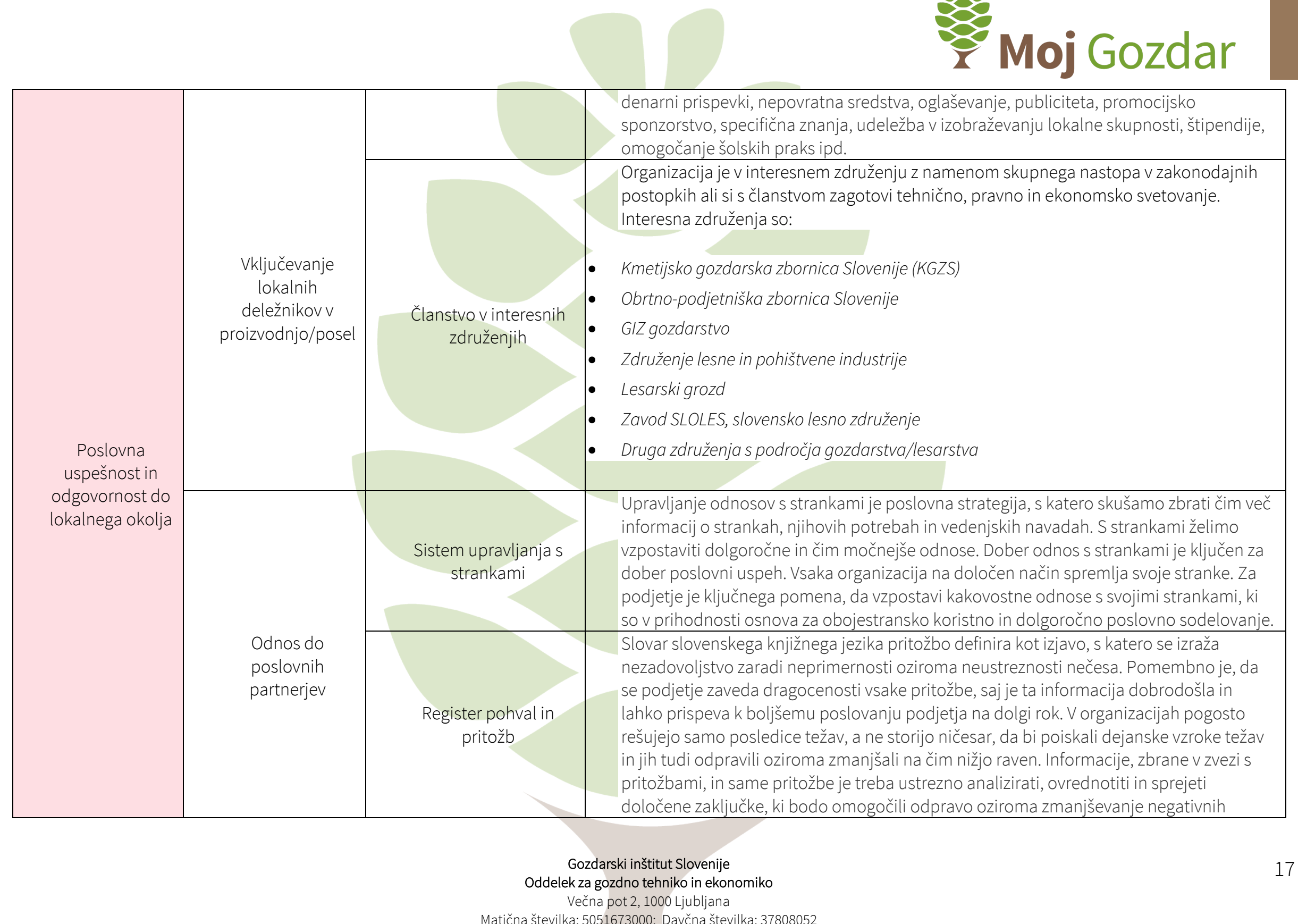

Matična številka: 5051673000; Davčna številka: 37808052 


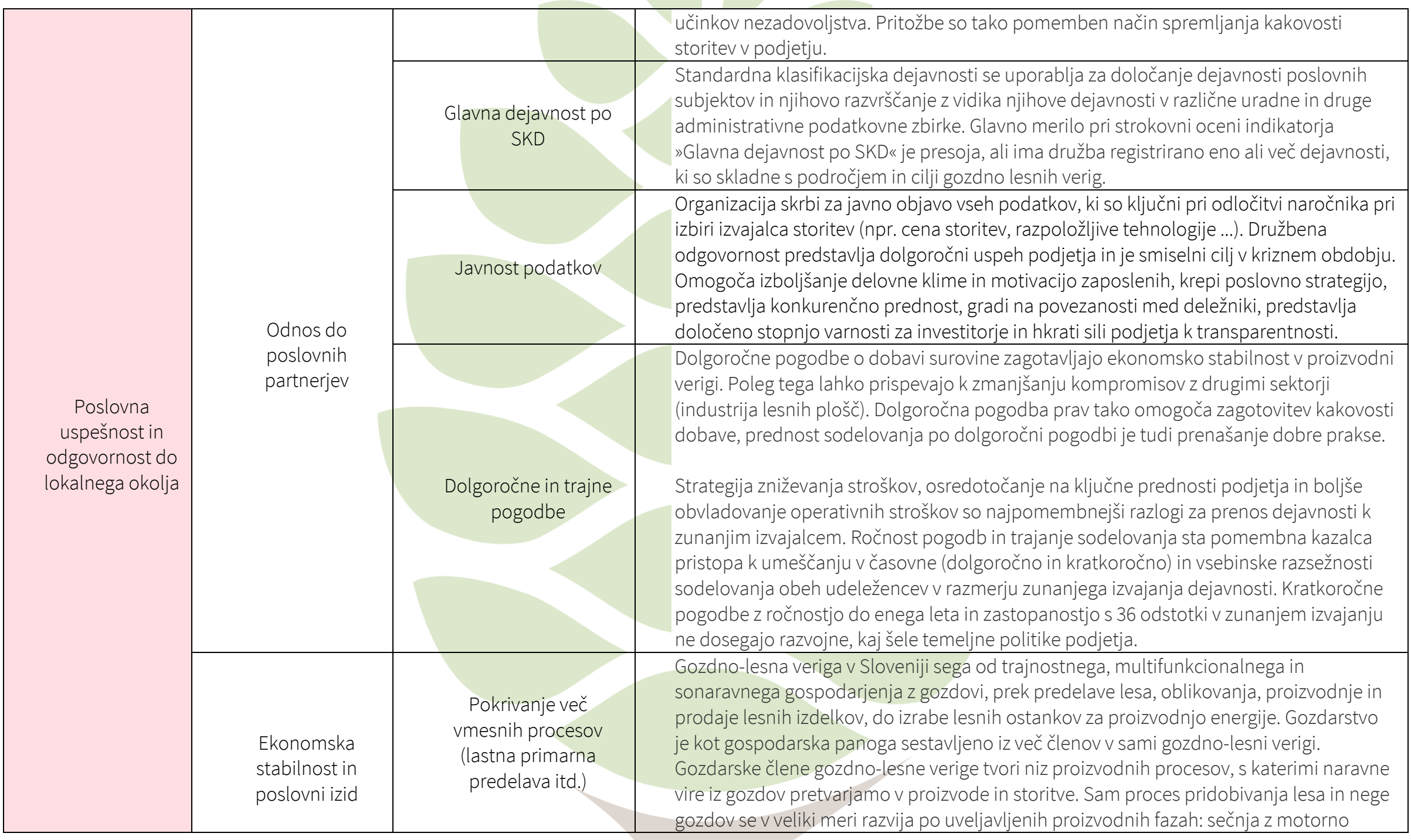

Gozdarski inštitut Slovenije

Oddelek za gozdno tehniko in ekonomiko

Večna pot 2, 1000 Ljubljana

Matična številka: 5051673000; Davčna številka: 37808052 

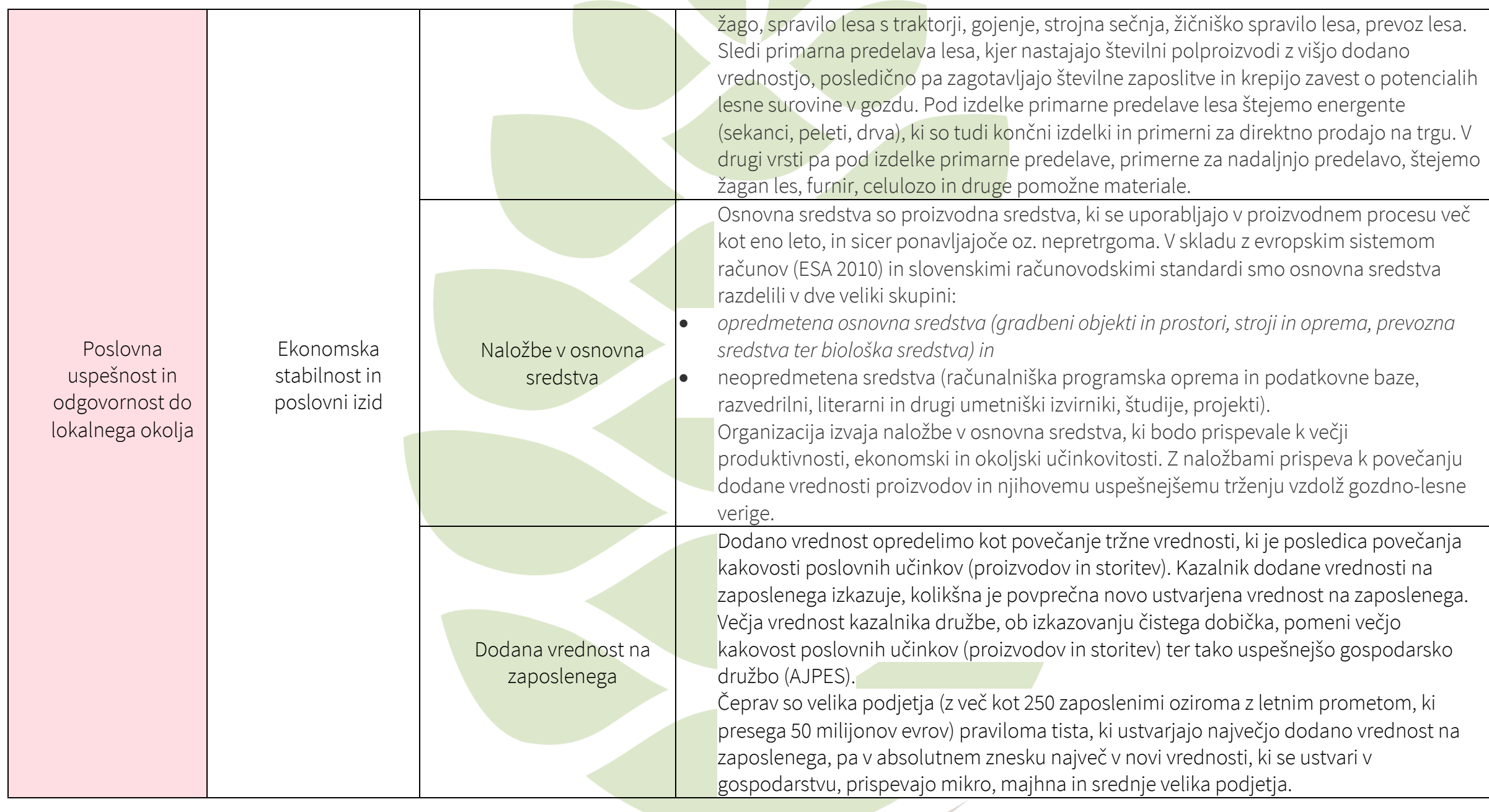

Gozdarski inštitut Slovenije 


\section{Strokovna ocena MojGozdar za ponudnike gozdarskih storitev}

Metodologija definira ključ (algoritem) in indikatorje (ter indikatorjem določa uteži), na podlagi katerih se ponudnikom dodeli strokovna ocena MojGozdar. Podatki (po indikatorjih) se zbirajo na več načinov:

- z ročnim vpisom podatkov v nastavljene obrazce neposredno prek spletnega informacijskega sistema MojGozdar,

- s povezovanjem na druge spletne podatkovne baze (AJPES, IKGLR, FURS).

Strokovno oceno MojGozdar se podaja na podlagi:

- osnovnih primarnih virov podatkov o poslovnih subjektih (AJPES, Sodni register, FURS, Inšpektorat RS za kmetijstvo...) in

- (spletnega) obrazca, na podlagi katerega reprezentativni predstavnik za vse indikatorje poda potrebne podatke in ustrezna dokazila. Spletni vprašalnik omogoča vnos popravkov oz. spremembo podatkov ali ponovni vnos celotnega spletnega vprašalnika.

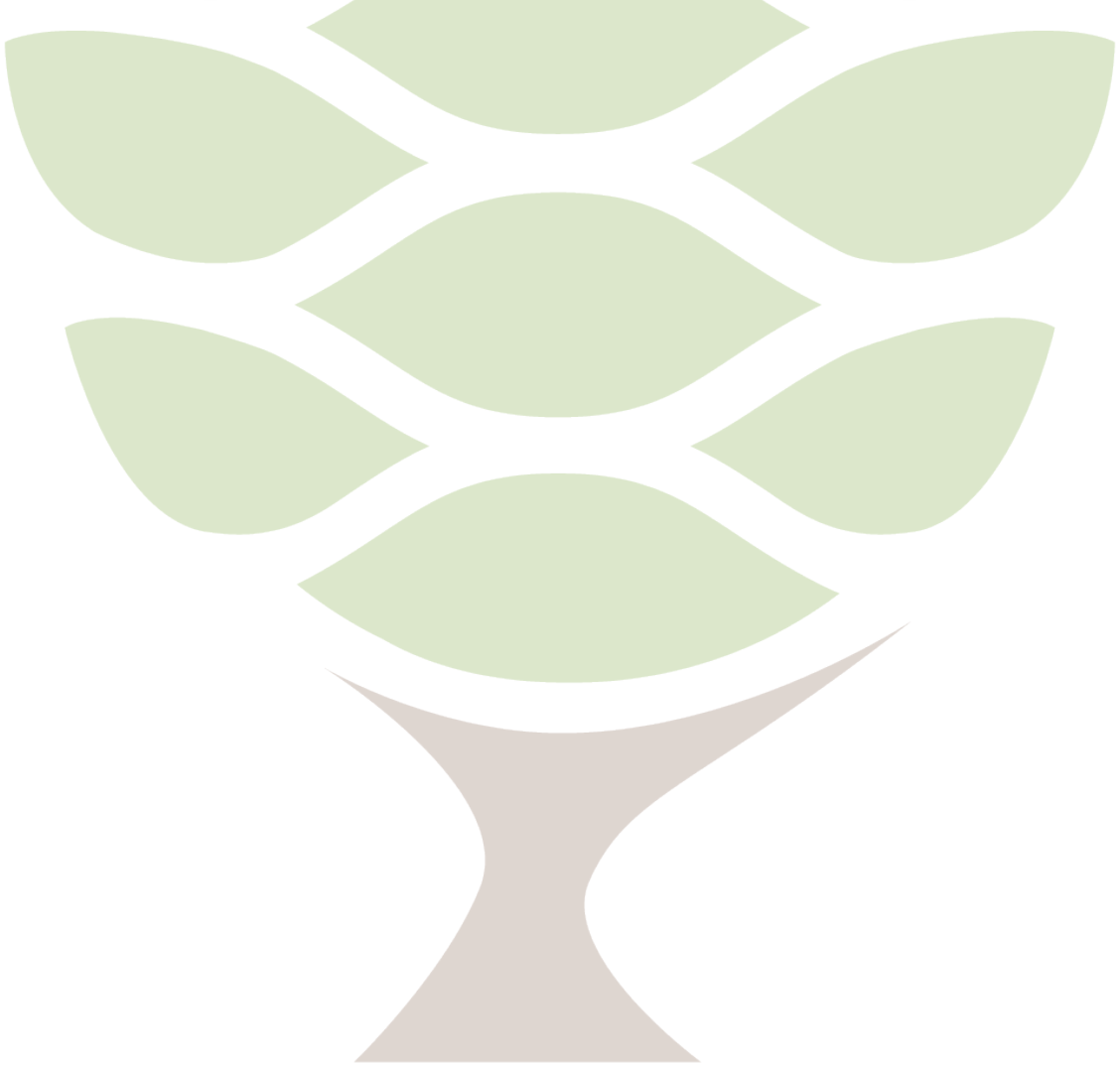




\section{Pravila strokovne ocene MojGozdar}

Vstop v strokovno oceno MojGozdar je prostovoljen. Ponudnik in Gozdarski inštitut Slovenije na pobudo ponudnika skleneta pogodbo o sodelovanju za pridobitev strokovne ocene MojGozdar. Predmet pogodbe je določitev medsebojnih pravic in obveznosti glede pridobitve strokovne ocene MojGozdar in uporabe znaka MojGozdar.

Podpisu pogodbe sledi podporni del strokovne ocene MojGozdar. Podporni del strokovne ocene MojGozdar omogoča ponudniku podporo pri pripravi spletne vloge in predstavitev indikatorjev, ki bodo ponudniku omogočili izpolnjevanje zahtev, potrebnih za pridobitev znamke. Podporni del strokovne ocene zajema tudi pregled in svetovanje glede indikatorjev z namenom doseči čim višji oceno.

Ponudnik izpolni spletno vlogo tako, da na sistem MojGozdar v obliki priponk priloži preslikana dokazila. Ob vsakem izbranem indikatorju je opis iz vnaprej določenih smernic, ki rabi kot razlaga pri zbiranju in pripravi dokazil.

- Skupno število možnih indikatorjev je 28.

- Indikatorji imajo vnaprej določeno število možnih točk.

- Indikatorji skupno prinesejo 100 točk.

- Noben indikator ni obvezen. Izvajalec sam presodi, katere bo predložil.

Obvestilo o izpolnjenem obrazcu skrbniku spletnega informacijskega sistema MojGozdar. V okviru presoje strokovne ocene MojGozdar s strani GIS pooblaščena oseba(v nadaljevanju presojevalec) opravi neodvisno strokovno presojo vloge, ki jo je ponudnik posredoval v presojo prek spletnega informacijskega sistema MojGozdar, ter določi, ali so dokazila ustrezna in za vsak izbrani indikator določi oceno ustreznosti. Na podlagi zadnje presoje se po vnaprej določeni enačbi dodeli ocena (storži) in vnos spletne vloge se onemogoči za čas trajanja neodvisne strokovne ocene.

\section{Speltni obrazec za vnos dokazil}

Obrazec vključuje naslednja polja:

- Naslov posameznega indikatorja

- Opis indikatorja

- Dodajanje datotek oz. dokazil

- Komentar izvajalca

- Ocena ustreznosti indikatorja

- Št. doseženih točk / št. možnih točk na indikator 


\section{Moj Gozdar}

PRIMER OBRAZCA ZA POSAMEZNI INDIKATOR:

\section{INDIKATOR $X_{1 . . . i}$}

$0 / X_{1}$ točk

Prostor za opis indikatorja in smernice za evalvacijo izbranega indikatorja. V smernicah je opredeljen nabor dejavnikov, ki morajo biti razvidni iz dokazil.

Polje za nalaganje priponk (predlagamo, da se izvajalcem omogoči, da naložijo več priponk)

\section{Choose File}

Prostor za komentar izvajalca

Oceno ustreznosti dodeli presojevalec na podlagi pregleda dokazil. Ocena ustreznosti je lahko v obliki »drop-down« menija ali »radio« gumbov. Ocena je lahko tudi v obliki storžev in se pretvori v deleže (npr. polovica storža ponazarja vrednost 0.1 , medtem ko 5 storžev ponazarja vrednost 1 ).

Prostor za komentar presojevalca

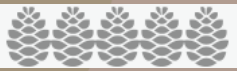

Legenda za programersko in oblikovalsko ekipo:

Prostor s statično opisno vsebino

Prostor, ki ga ureja/izpolnjuje izvajalec ocene)

Prostor, ki ga ureja/izpolnjuje presojevalec (skrbnik neodvisne strokovne 


\section{Uteži posameznih indikatorjev}

Že na prvi pogled je jasno, da so določeni indikatorji bolj pomembni od drugih in s tem se postavlja vprašanje, kako jih ovrednotiti oz. jim določiti uteži. V projektni skupini je prevladalo mnenje, da se v določanje uteži vključi večje število deležnikov. Za določanje uteži je bila izbrana metoda Analytic Hierarchy Process, ki temelji na parnih primerjavah. Oblikovan je bil poseben obrazec MS Excel, na podlagi katerega so udeleženci presojali vse možne pare. Gre za precej obsežno metodo, saj je moral vsak od anketirancev presojati okvirno 100 parov. Tako je izvedba ankete trajala od 30 do 45 minut. Strokovno mnenje je podalo 70 deležnikov. Končni rezultat izmenjave mnenj je seznam indikatorjev in njim pripadajoče maksimalne vrednosti (uteži). Pri anketah je sodelovalo 12 predstavnikov ponudnikov storitev, 11 predstavnikov društev lastnikov gozdov, 25 raziskovalcev, 4 predstavniki svetovalne službe za kmetijstvo in gozdarstvo in 4 predstavniki ministrstva in 14 predstavnikov javne gozdarske službe, skupaj torej 70 anketirancev.

\section{Preglednica 2: Razvrstitev anketirancev po interesni skupini, izobrazbi in starosti}

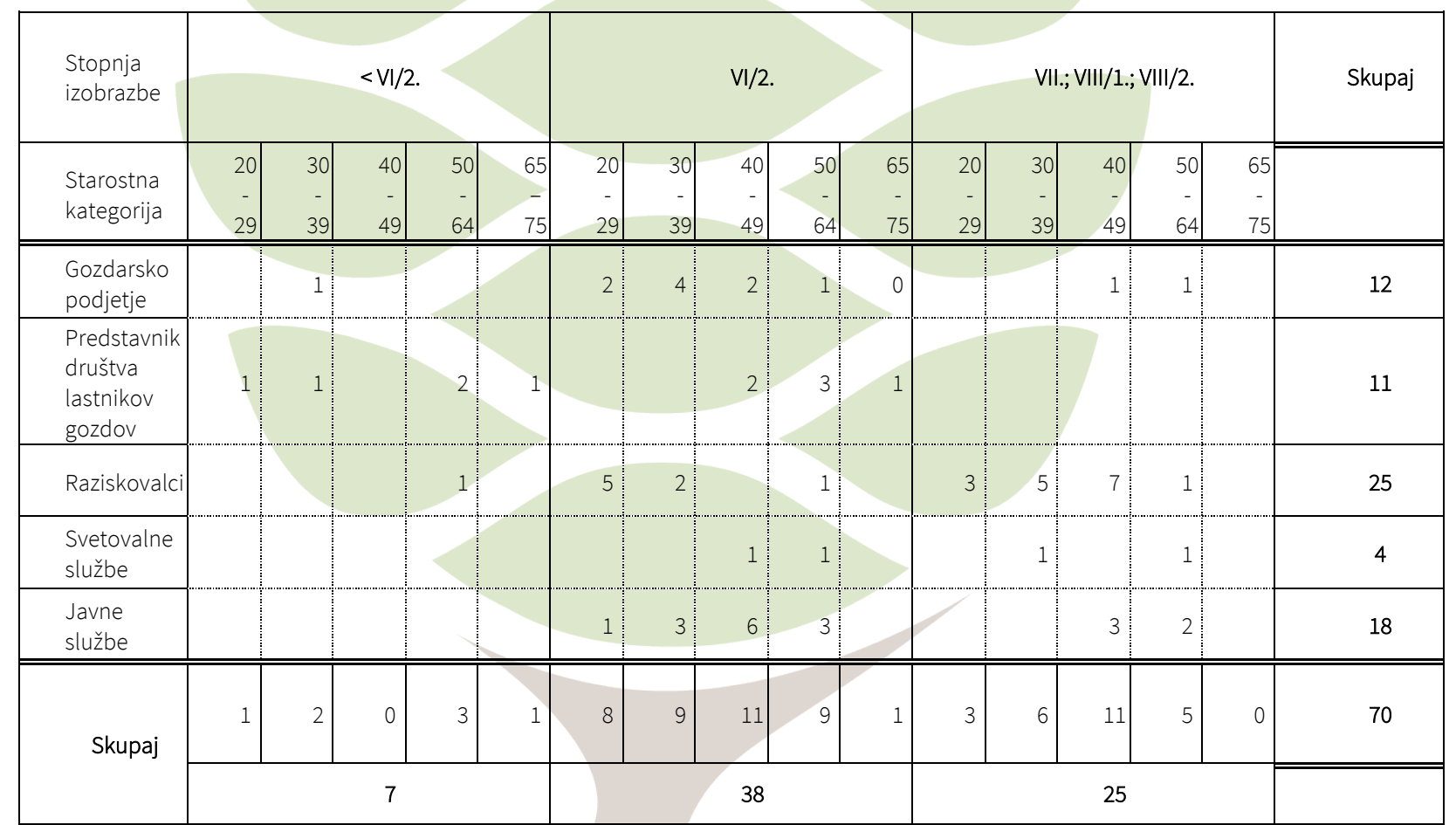




\section{Preglednica 3: Uteži po indikatorjih}

Poklicno usposabljanje zaposlenih

Strokovna izobrazba zaposlenih

Pogodbe o zaposlitvi

Družbena odgovornost do zaposlenih

Zaposlovanje invalidov

Periodični pregled strojev in opreme

Služba za zagotavljanje varnosti

Evidenca poškodb

$x_{1}$

Promocija zdravja na delovnem mestu

Sistem ravnanja z okoljem ISO 14001

Upravljanje z nevarnimi odpadki

Skladnost z okoljskimi omejitvami in zahtevami

Ravnanje s fitofarmacevtskimi sredstvi

$x_{2}$

$x_{3}$

Zmanjšanje emisij škodljivih snovi

Uporaba biorazgradljivih olj

Raba obnovljivih virov energije

FSC/PEFC certifikat

Varovanje sestoja, gozdnih tal, vodotokov in infrastrukture

$x_{5}$

Glavna dejavnost po standardni klasifikaciji dejavnosti (SKD)

Sistem upravljanja s strankami

Register pohval in pritožb

Javnost podatkov

Dolgoročne in trajne pogodbe

Pokrivanje več vmesnih procesov (lastna primarna predelava itd.)

Naložbe v osnovna sredstva

Dodana vrednost na zaposlenega

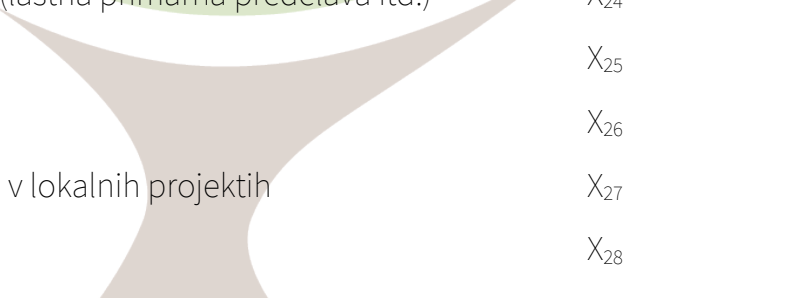

Sodelovanje ali finančna podpora v lokalnih projektih

Članstvo v interesnih združenjih

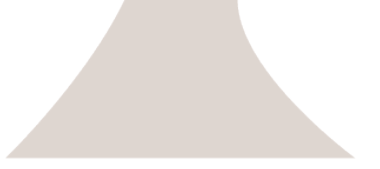




\section{Kriteriji za dodelitev strokovne ocene MojGozdar}

Ocene posameznih indikatorjev se izračunajo v skupno oceno po vnaprej določeni enačbi:

kjer je:

$$
X=X_{1} \times Y_{1}+X_{2} \times Y_{2}+\ldots+X_{28} \times Y_{28}
$$

X skupna ocena

$X_{i} \quad$ uteži posameznega indikatorja

$Y_{i} \quad$ delež ustreznosti indikatorja s strani presojevalca

Strokovna ocena MojGozdar se kategorizira po principu storžev. Upoštevajo se naslednje robne vrednosti:

- 1 storž pridobi ponudnik, ki v spletno vlogo za strokovno oceno vnese podatke o mehanizaciji in podatke o storitvah,

- 2 storža pridobi ponudnik, ki dosega 20 točk

- 3 storže pridobi ponudnik, ki dosega 30 točk

- 4 storže pridobi ponudnik, ki dosega 40 točk

- 5 storžev pridobi ponudnik, ki dosega 50 točk

\section{8 Časovni termin podelitve strokovne ocene MojGozdar}

Strokovna ocena MojGozdar se podeli za obdobje treh let. Načrtovani so letni nenapovedani pregledi, kjer GIS preveri dokumentacijo sistema MojGozdar. Ponudnik lahko dva meseca pred iztekom triletnega obdobja GIS zaprosi za podaljšanje nadzornega obdobja MojGozdar.

Obveznosti ponudnika po podelitvi strokovne ocene MojGozdar so naslednje:

- $\quad v$ roku enega meseca sporočiti vse spremembe, ki bi vplivale na spremembo kategorizacije znaka,

enkrat letno posodobiti podatke o stanju mehanizacije, ki jo uporablja za opravljanje storitve,

- enkrat letno poročati o količinah izvedenih storitev za storitve, ki jih ponuja prek spletnega informacijskega sistema MojGozdar,

- $\quad$ izpolniti druge določbe, ki mu jih bo presojevalec naložil s poročilom o skladnosti. 


\section{Opis dokumentacije po indikatorjih}

\subsection{Periodični pregled strojev in opreme}

$\checkmark$ Pravilniku o varnosti in zdravju pri uporabi delovne opreme (Uradni list RS, št. 101/2004; 43/2011) je delovna oprema opredeljena kot vsak stroj, aparat, orodje, naprava in druga oprema, ki se uporablja pri delu. Uporaba delovne opreme je vsaka dejavnost, pri kateri se uporablja delovna oprema, kot npr. zagon, uporaba in ustavitev opreme, njen transport, popravilo, vzdrževanje, sprememba, ki ne spreminja funkcionalnih lastnosti delovne opreme, strežba, servisiranje in čiščenje.

Šesti odstavek 19. člena Zakona o varnosti in zdravju pri delu (Uradni list RS, št. 43/2011) delodajalcu narekuje, da mora zagotavljati varnost in zdravje pri delu $v$ skladu z izjavo o varnosti z oceno tveganja tako, da z obdobnimi pregledi in preizkusi delovne opreme preverja njihovo skladnost s predpisi o varnosti in zdravju pri delu.

Po 9. členu Pravilnika o varnosti in zdravju pri uporabi delovne opreme, omenjenega $\checkmark$ prvem odstavku, mora delodajalec zagotoviti, da delovno opremo po namestitvi in pred prvim zagonom ali po premestitvi na drugo delovno mesto pregleda pristojna oseba, ki izda potrdilo, iz katerega je razvidno, da je delovna oprema pravilno nameščena in da deluje v skladu s predpisi. Prav tako mora delodajalec zagotoviti nadzor nad delovno opremo, katere uporaba je lahko škodljiva za delavce:

- z rednimi kontrolnimi pregledi in, kjer je potrebno, s preizkusi, ki jih opravijo pristojne osebe v skladu s predpisi,

- s posebnimi pregledi, ki jih opravijo pristojne osebe, če pride do izjemnih okoliščin, ki lahko ogrozijo varnost delovanja delovne opreme (npr. sprememba načina dela, poškodba opreme pri delu, nevarni pojav ali daljše obdobje nedelovanja), da se zagotovi upoštevanje varnostnih in zdravstvenih zahtev ter pravočasno odkrivanje in odpravljanje napak.

Delodajalec mora po 43. členu Pravilnika o varnosti in zdravja pri uporabi delovne opreme zagotoviti periodične preglede in preskuse delovne opreme v rokih, ki jih je določil proizvajalec. V primeru, da proizvajalec ne določi rokov za periodične preglede, mora delodajalec zagotoviti periodične preglede in preskuse v rokih, ki ne smejo biti daljši od 36 mesecev. Pravilnik o varnosti in zdravju pri uporabi delovne opreme $\vee 5$. členu narekuje, da mora delodajalec pridobiti in hraniti vso dokumentacijo, iz katere je razvidno, da delovna oprema ustreza predpisanim varnostnim in zdravstvenim zahtevam.

Periodične preglede delovne opreme lahko opravlja zunanja strokovna služba z ustreznim dovoljenjem za delo, ki ga izda Ministrstvo za delo, družino in socialne zadeve. Seznam ustreznih ponudnikov je objavljen na spletni strani ministrstva. 


\section{Moj Gozdar}

Pravilnik o pogojih in postopku za pridobitev dovoljenja za delo za opravljanje strokovnih nalog varnosti pri delu (Uradni list RS, št. 42/2003, 35/2011, 43/2011) določa, da lahko ustrezno usposobljen strokovni sodelavec opravlja periodične in druge preglede ter preizkuse delovne opreme. Pogoji za opravljanje strokovne naloge:

- za opravljanje naloge mora delavec imeti tehnično opremo iz točke B, Priloge 1 tega pravilnika,

- če delovna oprema, ki jo pregleduje, ni na seznamu opreme iz Priloge 2, mora imeti delavec višjo strokovno izobrazbo ustrezne tehnične smeri, 3 leta delovnih izkušenj in opravljen strokovni izpit s področja varnosti in zdravja pri delu,

- če je delovna oprema, ki jo pregleduje, na seznamu opreme iz Priloge 2, mora imeti delavec višjo strokovno izobrazbo ustrezne tehnične smeri, 5 let delovnih izkušenj in opravljen strokovni izpit s področja varnosti in zdravja pri delu.

Organizacija po pregledu opreme prejme Zapisnik o pregledu in preizkusu delovne opreme. Če so izpolnjeni vsi pogoji za varnost, prejme tudi potrdilo. Če pogoji niso izpolnjeni, so v zapisniku navedene pomanjkljivosti, ki jih mora organizacija odpraviti pred izdajo potrdila.

Trajni arhiv dokumentacije v zvezi s pregledi in preizkusi delovne opreme obsega:

- seznam delovne opreme,

- potrdilo in zapisnik o pregledu in preizkusu delovne opreme,

- proizvajalčevo dokumentacijo za delovno opremo (izjava o skladnosti, oznaka CE, navodila za uporabo),

- pisna navodila za varno delo z delovno opremo,

- dokumente o nadgradnji ali rekonstrukciji delovne opreme (tehnična mapa, ocena tveganja za stroj, izjava o skladnosti, oznaka CE, navodila za uporabo),

- dokumentacijo o izvedenih popravilih, servisih, vzdrževanju itd.

\section{Evalvacija indikatorja (točkovanje): Ustrezno(6 točk):}

- Organizacija zagotavlja nadstandardno vzdrževanje strojev, periodičnost pregledov je pogostejša, kot jo določa zakonski minimum oz. proizvajalec. Organizacija na ta način zagotavlja preventivne preglede, ki vplivajo na manjšo pogostost zastojev in okvar.

- Organizacija ima urejen trajni arhiv v zvezi s pregledi in preizkusi delovne opreme (zapisnik in potrdilo o pregledu in preizkusu delovne opreme).

\section{Delno ustrezno (3 točke):}

- Organizacija ima urejen trajni arhiv v zvezi s pregledi in preizkusi delovne opreme (zapisnik in potrdilo o pregledu in preizkusu delovne opreme). 


\section{Dokazila:}

\section{Moj Gozdar}

Organizacija priloži zadnji veljavni zapisnik in potrdilo o pregledu delovne opreme. Da organizacija vzdržuje stroje, priloži ustrezen dokument, na katerem je razvidno periodično preventivno vzdrževanje strojev (npr. dolgoročno pogodbo z zunanjim izvajalcem, ki opravlja preglede in vodi dnevnik pregledov zaposlenega notranjega strokovnega sodelavca).

\subsection{Služba za zagotavljanje varnosti in zdravja pri delu}

Zakon o varnosti in zdravju pri delu (Uradni list RS, št. 43/2011) določa pravice in dolžnosti delodajalcev in delavcev v zvezi z varnim in zdravim delom ter ukrepi za zagotavljanje varnosti in zdravja pri delu.

Delodajalec se lahko sam odloči, da bo vodenje in zagotavljanje varnosti in zdravja pri delu prevzel sam ali pa mora za to pooblastiti zunanjo osebo, ki mora imeti primerno strokovno izobrazbo in ustrezna potrdila. Zunanja strokovna služba je torej pravna oseba ali samostojni podjetnik, ki ima dovoljenje ministra, pristojnega za delo, za opravljanje strokovnih nalog in kateri delodajalec poveri opravljanje vseh ali posameznih strokovnih nalog varnosti pri delu. Delodajalec lahko opravljanje vseh ali posameznih nalog organiziranja in zagotavljanja varnosti pri delu pooblasti zunanje strokovne službe, katere mora seznaniti z vsemi dejavniki, ki vplivajo ali bi lahko vplivali na varnost in zdravje delavcev pri delu. Te službe morajo imeti omogočen dostop do podatkov o tveganjih, varnostih in preventivnih ukrepih ter o delavcih, zadolženih za izvajanje ukrepov.

Če se delodajalec odloči, da bo vodenje in zagotavljanje varnosti in zdravja pri delu prevzel sam, mora to delo opravljati usposobljen strokovni delavec. Pravilnik o pogojih in postopku za pridobitev dovoljenja za delo za opravljanje strokovnih nalog varnosti pri delu (Uradni list RS, št. 42/2003, 35/2011, 43/2011) določa, da lahko posameznik pridobi dovoljenje za opravljanje naslednjih strokovnih nalog:

1. Opravljanje periodičnih in drugih preiskav fizikalnih, kemičnih in bioloških škodljivosti v delovnem okolju.

Pogoji za opravljanje strokovne naloge:

- delavec mora imeti visoko strokovno izobrazbo ustrezne tehnične smeri,

- 3 leta delovnih izkušenj,

- opravljen strokovni izpit s področja varnosti in zdravja pri delu,

- za opravljanje naloge mora delavec imeti tehnično opremo iz točke A, Priloge 1 tega pravilnika.

\section{Opravljanje periodičnih in drugih pregledov in preizkusov delovne opreme.}

Pogoji za opravljanje strokovne naloge: 


\section{Moj Gozdar}

- za opravljanje naloge mora imeti delavec tehnično opremo iz točke B, Priloge 1 tega pravilnika,

- če delovna oprema, ki jo pregleduje, ni na seznamu opreme iz Priloge 2, mora imeti delavec višjo strokovno izobrazbo ustrezne tehnične smeri, 3 leta delovnih izkušenj in opravljen strokovni izpit s področja varnosti in zdravja pri delu,

- če je delovna oprema, ki jo pregleduje, na seznamu opreme iz Priloge 2, mora imeti delavec višjo strokovno izobrazbo ustrezne tehnične smeri, 5 let delovnih izkušenj in opravljen strokovni izpit s področja varnosti in zdravja pri delu.

\section{Izdelovanje strokovnih podlag za izjavo o varnosti.}

Pogoji za opravljanje strokovne naloge:

- delavec mora imeti visoko strokovno izobrazbo ustrezne tehnične smeri, 3 leta delovnih izkušenj in opravljen strokovni izpit s področja varnosti in zdravja pri delu,

- delavec ima lahko tudi visoko strokovno izobrazbo z naslovom varnostni inženir, 10 let delovnih izkušenj in opravljen strokovni izpit s področja varnosti in zdravja pri delu.

\section{Pripravljanje in usposabljanje delavcev za varno delo.}

Pogoji za opravljanje strokovne naloge:

- delavec mora imeti visoko strokovno izobrazbo ustrezne tehnične smeri, 3 leta delovnih izkušenj, opravljen strokovni izpit s področja varnosti in zdravja pri delu in osnovna andragoška znanja,

- osnovna andragoška znanja se dokazujejo s potrdilom o opravljenem usposabljanju v obsegu 24 pedagoških ur.

Opravljen strokovni izpit je pogoj za opravljanje vseh zgoraj naštetih strokovnih nalog. V Prilogi 2, Pravilnika o opravljanju strokovnega izpita iz varnosti in zdravja pri delu (Uradni list RS, št. 109/2011) je opredeljeno, da udeleženec, ki pristopi k opravljanju izpita, pridobi znanja in obdobne preglede in preizkuse delovne opreme:

1. način pridobivanja vhodnih podatkov za izvedbo obdobnih pregledov in preizkusov delovne opreme,

2. varnost proizvodov,

3. izvedba obdobnih pregledov in preizkusov delovne opreme:

a. postopek preiskave posameznega parametra

b. merjenje posameznih veličin

c. dokumentiranje rezultatov meritev z navedbo referenčnih vrednosti

d. postopki v primeru neustreznosti

4. postopki, ki se uporabljajo pri obdobnih pregledih in preizkusih delovne opreme, 


\section{Moj Gozdar}

5. tehnična oprema, ki je potrebna za izvedbo obdobnih pregledov in preizkusov delovne opreme,

6. vsebina zapisnika in potrdila,

7. predpisi in standardi, ki so podlaga za izvedbo obdobnih pregledov in preizkusov delovne opreme.

\section{Evalvacija indikatorja (točkovanje): Ustrezno (4 točke):}

Organizacija je usposobila ali zaposlila strokovnega delavca, ki opravlja naloge varnosti pri delu.

\section{Dokazila:}

Podjetje priloži dokument, s katerim dokazuje, da zaposluje strokovnega delavca, ki izpolnjuje pogoje za opravljanje nalog s področja varnosti pri delu.

\subsection{Evidenca poškodb}

Po 66. in 67. členu Zakona o pokojninskem in invalidskem zavarovanju (Uradni list RS, št. 96/2012) se za poškodbo pri delu šteje poškodba, ki je posledica neposrednega in kratkotrajnega mehaničnega, fizikalnega ali kemičnega učinka, ter poškodba, ki je posledica hitre spremembe položaja telesa, nenadne obremenitve telesa ali drugih sprememb fizioloških stanj organizma, če je takšna poškodba v vzročni zvezi z opravljanjem dela ali dejavnosti, na podlagi katere je poškodovanec zavarovan. Za poškodbo pri delu se šteje tudi poškodba, ki jo pretrpi poškodovanec na redni poti od stanovanja do delovnega mesta ali nazaj, na službeni poti ali na poti, da nastopi delo, ter tudi obolenje, ki je neposredna in izključna posledica nesrečnega naključja ali višje sile med opravljanjem dela.

Na podlagi 41. člena Zakona o varnosti in zdravja pri delu (Uradni list RS, št. 43/2011) mora delodajalec $v$ najkrajšem možnem času Inšpektoratu Republike Slovenije za delo prijaviti vsako nezgodo pri delu s smrtnim izidom oz. nezgodo pri delu, zaradi katere je delavec nezmožen za delo več kot tri delovne dni, kolektivno nezgodo, nevarni pojav in ugotovljeno poklicno bolezen. Prav tako 59. člen zakona opredeljuje, da mora samozaposlena oseba inšpekciji dela prijaviti nezgodo pri delu, zaradi katere je nezmožna za delo več kot tri delovne dni, ugotovljeno poklicno bolezen ali nevaren pojav.

Pravilnik o prijavah na področju varnosti in zdravja pri delu (Uradni list RS, št. 54/2013) v2. členu določa, da delodajalec prijavi nezgodo pri delu na obrazcu ER-8, ki je priloga omenjenemu pravilniku. Za izpolnjevanje obrazca potrebujemo navodila, šifrante ter opis in pojasnila posameznih podatkov. Podatki, ki se zberejo na nivoju države in Evropske unije so pomembni za preprečevanje nezgod v bodoče. Obrazec obsega dve 


\section{Moj Gozdar}

strani in ga je treba izpolniti v štirih izvodih. En potrjeni izvod se vrne delodajalcu, en izvod se hrani v medicinski dokumentaciji poškodovanca pri osebnem zdravniku, dva izvoda pa izbrani zdravnik posreduje Zavodu za zdravstveno zavarovanje Slovenije, od katerih en izvod prejme Nacionalni inštitut za varovanje zdravja. Delodajalec mora po 61. členu Zakona o varnosti in zdravja pri delu (Uradni list RS, št. 43/2011) hraniti vso dokumentacijo, ki se nanaša na nezgode pri delu, kolektivne nezgode, nevarne pojave, ugotovljene poklicne bolezni in bolezni, povezane z delom, ter njihove vzroke.

Podjetje oz. organizacija mora voditi evidenco o nezgodah pri delu in poškodbe, ki se zgodijo njihovim zaposlenim/izvajalcem. Za doseganje omenjenega kriterija lahko služi shranjena dokumentacija o nezgodah (potrjeni obrazci ER-8) ali kakšna druga podatkovna zbirka o nezgodah. Ta mora vsebovati sklop podatkov o delodajalcu, poškodovancu in prijavitelju. Najpomembnejši pa so seveda podatki o sami nezgodi.

Podatki o nezgodi so ključni za nadaljnjo analizo same nezgode, ki jo mora po dogodku opraviti organizacija. Vsako nezgodo je treba raziskati ne glede na njeno pomembnost, saj tako zmanjšamo možnost ponovitve podobnega dogodka. Z interno raziskavo želimo torej ugotoviti temeljni vzrok za nastanek le-te. Ko razjasnimo vzroke za nastanek nezgode, sledi priprava preventivnih ukrepov za preprečitev ponovne tvegane situacije. $V$ končni fazi napravimo revizijo ocene tveganja na delovnem mestu in program usposabljanja za vse zaposlene.

\section{Evalvacija indikatorja (točkovanje): Ustrezno (2 točki):}

- Organizacija je po nezgodi v obliki tehničnih rešitev ali izobraževanja za zaposlene sprejela ukrepe za preprečitev podobnih nezgod v prihodnje.

\section{Dokazila:}

Organizacija mora priložiti skeniran dokument, s katerim dokazuje, da je opravila interno raziskavo dogodka in sprejela ukrepe za preprečitev nadaljnjih podobnih nezgod. Ukrepi so lahko izvedeni na različne načine, kot primer jih navajamo v obliki tehničnih rešitev in izobraževanja. V primeru, da se je podjetje odločilo za ukrepe $v$ obliki tehničnih rešitev, priloži račun nabavljene opreme (npr. račun senzorjev proti prevrnitvi traktorja). Če je bil ukrep izveden v obliki izobraževanja, organizacija priloži račun plačila akontacije za izobraževanje.

\subsection{Promocija zdravja na delovnem mestu}

Promocija zdravja na delovnem mestu so sistematične ciljane aktivnosti in ukrepi, ki so namenjeni vsem delavcev. Opravljajo se za vse delavce pod enakimi pogoji, z namenom ohranjanja in krepitve telesnega in duševnega zdravja zaposlenih. 


\section{Moj Gozdar}

Pravne podlage podaja Zakon o varnosti in zdravja pri delu (ZVZD-1; UL 43/11; v nadaljevanju: zakon). V skladu s 6. in 32. členom tega zakona mora delodajalec promocijo zdravja na delovnem mestu načrtovati ter zanjo zagotoviti potrebna sredstva in tudi način spremljanja njenega izvajanja. Ministrstvo, pristojno za zdravje, izda smernice za določitev in pripravo promocije zdravja na delovnem mestu. Smernice se objavljene na spletni strani ministrstva, pristojnega za zdravje, in ministrstva, pristojnega za delo. Po omenjenih smernicah mora delodajalec promocijo zdravja na delovnem mestu načrtovati v izjavi o varnosti z oceno tveganja, kar določa 27. točka 76. člena zakona. Načrt promocije zdravja na delovnem mestu je lahko priloga/aneks k obstoječi oceni tveganja, ki jo podpiše direktor.

Promocija zdravja na delovnem mestu je skupno prizadevanje delavcev, delodajalcev in družbe za izboljšanje zdravja in dobrega počutja ljudi pri njihovem delu. Lahko rečemo, da gre za aktivno podporo delodajalca pri izboljšanju splošnega zdravja in dobrega počutja zaposlenih. Bolj zdrav delavec je posledično tudi bolj zadovoljen, hkrati pa to pomeni manjše stroške za delodajalca in zdravstveno zavarovalni sistem zaradi bolniških odsotnosti. Za učinkovito pripravo in uresničevanje programa promocije zdravja in dobrega počutja so ključna sledeča načela:

- programi promocije zdravja so komplementarni z zakonskimi zahtevami s področja varnosti in zdravja pri delu,

- program je stroškovno učinkovit (in ne nujno drag),

- vsebine programov naj izhajajo iz potreb zaposlenih,

- program izvajajo zaposleni,

- program je prostovoljen,

- programi naj vključujejo ukrepe/aktivnosti, usmerjene v organizacijo dela, delovno okolje in spremembe vedenj posameznika,

- trajnost izvajanja promocije zdravja na delovnem mestu.

\section{Evalvacija indikatorja (točkovanje): Ustrezno (2 točki):}

- Organizacija ima izdelan program promocije zdravja na delovnem mestu.

- Če organizacija nima izdelanega programa promocije zdravja na delovnem mestu, svojim delavcem zagotavlja eno izmed naslednjih aktivnosti:

- promoviranje zdrave prehrane (sadje na delovnem mestu itd.)

- promoviranje telesne dejavnosti (kolektivna udeležba na športnih tekmovanjih, tedenska rekreacija delavcev, nabava koles za transportno mobilnost itd.)

o izboljšanje delovnega okolja (motivacijske delavnice itd.)

\section{Dokazila:}

Podjetje priloži program promocije zdravja na delovnem mestu. Lahko je kot priloga/aneks k »lzjavi varnosti z oceno tveganja«. S tem podjetje dokazuje, da po 27. 


\section{Moj Gozdar}

točki 76. člena Zakona o varnosti in zdravja pri delu izvaja promocijo zdravja na delovnem mestu. V primeru, da organizacija opravlja le določene aktivnosti, ki sledijo smernicam promocije zdravja na delovnem mestu, priloži račun, ki potrjuje opravljanje dejavnosti (račun o nabavi koles, plačilu tedenske rekreacije, plačilo akontacije na športnih tekmovanjih itd.).

\subsection{Poklicno usposabljanje zaposlenih}

Učenje $v$ organizaciji je proces, s katerim organizacija spoznava procese in stanja $v$ okolju in se jim prilagaja. Ker je okolje zelo turbulentno, se mora organizacija velikokrat odzvati zelo hitro. Uspešnejša je tista organizacija, ki se uči hitreje.

Izobraževanje ima vsekakor ugodne učinke, zato se morajo člani organizacije učiti (Ferjan, 1999). Izobraževanje se nanaša na pridobivanje znanj, izobrazbe za določeno delo; usposabljanje pa je zasnovano na oblikovanju sposobnosti, spretnosti, navad, ki jih posameznik potrebuje za izvajanje določenega dela, nalog. Učenje je kompleksno povezovanje pridobljenih znanj, njihovo prilagajanje in uresničevanje v praksi (Možina in sod., 2002). Ne glede na to, ali je temeljna dejavnost organizacije proizvodnja ali opravljanje storitev, je izobražen in usposobljen kader temeljni dejavnik razvoja, kakovosti in uspešnosti. Izobraževanje, izpopolnjevanje in usposabljanje na delovnem mestu zato vse bolj pridobivajo na veljavi. Organizacije se vse bolj zavedajo, da sodi izobraževanje med ključne dejavnike, ki vplivajo na pridobivanje in vzdrževanje konkurenčne prednosti vsakega podjetja.

Zakon o delovnih razmerjih (Uradni list RS, št. 21/13; 78/13; 47/15; 33/16; 52/16; 15/17) opredeljuje izobraževanje delavcev $\vee 170$. in 171. členu. Delavec ima pravico in dolžnost stalnega izobraževanja, izpopolnjevanja in usposabljanja v skladu s potrebami delovnega procesa, z namenom ohranitve oziroma širitve sposobnosti za opravljanje dela po pogodbi o zaposlitvi, ohranjanje zaposlitve ter povečanja zaposljivosti. Delodajalec je dolžan zagotoviti usposabljanje delavcev, če tako zahtevajo potrebe delovnega procesa, ali če se je z izobraževanjem moč izogniti odpovedi pogodbe o zaposlitvi iz razloga nesposobnosti ali poslovnega razloga. Če delodajalec napoti delavca na izobraževanje iz zgoraj naštetih razlogov, potem tudi sam nosi stroške izobraževanja. Prav tako ima delavec, ki se izobražuje, izpopolnjuje ali usposablja po napotitvi delodajalca ali v lastnem interesu, pravico do odsotnosti z dela zaradi priprave oziroma opravljanja izpitov. Podrobneje to področje ureja sama pogodba o izobraževanju ali kolektivna pogodba.

Kolektivna pogodba za gozdarstvo (Uradni list RS, št.16/05; 37/06; 19/08; 99/08; 30/09; 46/10; 44/15) prav tako določa, da imajo delavci pravico, da se izobražujejo v svojem lastnem interesu ali v interesu delodajalca, delodajalec pa ima pravico, da delavce napoti na izobraževanje. Delavcu, ki se izobražuje v interesu delodajalca in je to organizirano med delovnim časom, se čas izobraževanja šteje $v$ redni delovni čas, 


\section{Moj Gozdar}

delavec pa ima tudi enake pravice, kot bi delal. Če je izobraževanje organizirano zunaj delovnega časa (izobraževanje ob delu), pripadajo delavcu najmanj:

- $\quad$ trije delovni dnevi za vsak izpit na ravni izobraževanja do V. stopnje zahtevnosti,

- pet delovnih dni za vsak izpit na višji in visoki stopnji izobraževanja,

- deset delovnih dni za zaključni izpit na ravni izobraževanja do V. stopnje zahtevnosti,

- petnajst delovnih dni za diplomo na višji ali visoki šoli,

- deset delovnih dni za vsak izpit na podiplomskem študiju,

- petindvajset delovnih dni za magistrski izpit,

- petindvajset delovnih dni za doktorat,

- deset delovnih dni za strokovni izpit.

Zgoraj našteto delavcu pripada v primeru, ko prvič opravlja izpit. Poleg tega mu pripada povračilo stroškov, povezanih z izobraževanjem: prevoz, kotizacija, šolnina, stroški prehrane in stroški bivanja. Ključna pa je pogodba o izobraževanju, ki je sklenjena med delodajalcem in delavcem. Znotraj nje se določijo vse obveznosti in pravice $v$ relaciji med delodajalcem in delavcem. Delodajalec mora delavcu, ki ga je napotil na izobraževanje, po uspešno zaključenem izobraževanju zagotoviti ustrezno delo $v$ skladu s pridobljeno izobrazbo. $V$ primeru, da delavec ne izpolni svojih obveznosti iz pogodbe, je dolžan delodajalcu povrniti vse stroške izobraževanja.

Traven (1998) navaja, da je proces usposabljanja sestavljen in naslednjih faz: določitev potreb po usposabljanju, določitev ciljev usposabljanja, oblikovanje načrta programov usposabljanja, zagotovitev izvedbe usposabljanja, izvedba, ocenitev in po potrebi izboljšava. Potrebe po usposabljanju se lahko predvidevajo na podlagi različnih kazalnikov, kot so težave pri opravljanju nalog, nova tehnologija, preoblikovanje vrste dela, novi zakonski predpisi, spremembe $v$ porabnikovih zahtevah, novi proizvodi ali pomanjkanje spretnosti zaposlenih delavcev. Na podlagi omenjenih kazalnikov lahko ugotovimo, ali usposabljanje ustreza strateškim ciljem podjetja. Glede na potrebe se oblikuje načrt usposabljanja. Oceno uspešnosti usposabljanja opravimo z namenom, da ugotovimo, ali je bilo usposabljanje glede na vložene stroške in pridobljene koristi uspešno ter kakšne izboljšave pri usposabljanju so še mogoče, da bi bilo to še učinkovitejše in stroškovno ugodneje.

\section{Evalvacija indikatorja (točkovanje): Ustrezno (9 točk):}

- Organizacija ima z zaposlenimi sklenjeno pogodbo o izobraževanju.

- Organizacija ima za svoje zaposlene izdelan načrt usposabljanja.

- Organizacija skrbi za redno izobraževanje ali usposabljanje zaposlenih in tudi krije stroške izobraževanj. 


\section{Dokazila:}

\section{Moj Gozdar}

Organizacija priloži skenirano individualno pogodbo o izobraževanju in načrt usposabljanja za svoje zaposlene. Poleg individualne pogodbe o izobraževanju kot dokazilo šteje tudi eden izmed navedenih dokumentov:

- skenirani certifikati, ki jih zaposleni pridobijo na izobraževanjih (licence za arboriste itd.),

- skeniran račun plačila kotizacije za seminarje (npr. strokovno - raziskovalni dogodki),

- druga potrdila o usposabljanjih (usposabljanje za delo z arboristično vrvno tehniko, upravljanje dvižne košare).

\subsection{Strokovna izobrazba zaposlenih}

Podjetja si želijo ustrezno izobraženo in usposobljeno delovno silo, saj jim slednja pomeni pot do uspeha in konkurenčne prednosti na trgu. Da bi to dosegla, morajo aktivno delovati na področju izobraževanja svojih zaposlenih in jih ustrezno motivirati za vključevanje v dodatna izobraževanja (Keser, 2012).

Če je bilo $v$ preteklosti fizično premoženje podjetja poudarjeno kot ključni vir uspešnosti, pa v današnjem času dajemo primarno vlogo človeškemu kapitalu. Kovač (1999) človeški kapital definira kot zmožnost in sposobnost zaposlenih, da s svojim znanjem in izkušnjami sodelujejo v delovnem procesu ter rešujejo poslovne probleme. Visoka stopnja človeškega kapitala namreč pomembno vpliva na višjo stopnjo učinkovitosti in uspešnosti organizacije, in sicer predvsem na višjo stopnjo profitabilnosti, rasti in razvoja organizacije, zadovoljevanje konkurenčne prednosti in višjo stopnjo ugleda organizacije.

Uspešnost podjetja kot celote je tako odvisna od posameznika in njegove delovne uspešnosti. Organizacije se vse bolj zavedajo, da so njihovi zaposleni lahko ključni dejavnik pri pridobivanju določenih konkurenčnih prednosti pred drugimi organizacijami, zato ogromno vlagajo v znanje zaposlenih.

Pogosto se srečujemo s pojmoma usposabljanje in izobraževanje. Pri usposabljanju govorimo o procesu, ki je specifično usmerjen $v$ razvijanje posameznikovih sposobnosti, ki jih ta potrebuje za opravljanje natančno določenega dela. Po drugi strani pa formalno izobraževanje posameznika pripravlja za več možnih delovnih situacij, navzven pa se to kaže v enotnosti znanj in sposobnosti. Lipuš (2011) navaja, da je dodatno praktično usposabljanje le komplementarno splošnemu izobraževanju, ki pa ga ne more zamenjati. Brez zadostne osnove in temeljne izobrazbe delovno izkustvo in dodatno izobraževanje nimata pomembnega učinka na produktivnost. 


\section{Evalvacija indikatorja (točkovanje): Ustrezno (7 točk):}

\section{Moj Gozdar}

- V organizaciji je zaposlenih vsaj 20 \% osebja z izobrazbo podravni 6/1 (tj. višješolsko in višje strokovno izobraževanje/višješolska, višja strokovna in podobna izobrazba).

\section{Dokazovanje:}

Organizacija za dokazovanje priloži preslikane dokumente spričevala zaposlenih, ki dosegajo navedeno raven izobrazbe. Zadostuje tudi, da organizacije omogoči vpogled v dokumentacijo s strani skrbnika pooblaščeni osebi med podpornim obiskom.

\subsection{Pogodbe o zaposlitvi}

Cilj vsakega delodajalca je ustvariti podjetje, ki z uspešnim poslovanjem ustvarja čisti dobiček. Za dosego tega cilja mora podjetje širiti svoje poslovanje, kar pomeni, da mora delodajalec zaposliti usposobljene delavce, ki jim lahko zaupa in so motivirani za dobro opravljanje svojega dela ter pripravljeni to delo tudi nadgrajevati. Postopek zaposlovanja je v Republiki Sloveniji že utečena praksa. Delodajalec najprej objavi prosto delovno mesto, na katero se prijavijo potencialni delavci. Med njimi izbere primerne kandidate, ki jih povabi na razgovor, nato pa na podlagi tega izbere ustreznega kandidata, s katerim podpišeta pogodbo o zaposlitvi. Pogodba o zaposlitvi je pravni akt, ki ureja delovno razmerje med delodajalcem in delojemalcem. Najbolj tipična je pogodba o zaposlitvi za nedoločen čas, vendar pa so med delodajalci vedno bolj priljubljene tudi atipične pogodbe o zaposlitvi, kot so: pogodba o zaposlitvi za določen čas, pogodba o zaposlitvi za krajši delovni čas, pogodba o zaposlitvi za delo na domu ipd. Z zakonom, kolektivno pogodbo in splošnimi akti so urejene pravice, obveznosti in odgovornosti delodajalca in delavca. Delodajalec mora delavca ob začetku dela seznaniti z vsemi obveznostmi in odgovornostmi, ki jih bo imel pri opravljanju dela. Prav tako mora delodajalec delavcu zagotoviti delo, plačilo za delo in varnost pri delu (Peternelj, 2012).

Za uspešnost in kakovost opravljenega dela je zelo pomembna motivacija, ki delavca spodbuja za nadaljnje delo in ga vodi k doseganju ciljev. Motivacijo lahko ločimo na notranjo in zunanjo. Notranja motivacija je predvsem odvisna od osebnih lastnosti posameznika in se kaže kot lastna želja zaposlenega za doseganje skupnih ciljev. K zunanji motivaciji pa sodijo odnosi s sodelavci, plačilo za delo, napredovanje itd. Motivacija torej zaposlenim prinaša zadovoljstvo, kar na dolgi rok pomeni uspešnost delovnih procesov, ki zadovoljstvo prinašajo tudi delodajalcu (Peternelj, 2012).

Po sklenitvi pogodbe o zaposlitvi je delodajalec dolžan delavca prijaviti v obvezna socialna zavarovanja (zdravstveno, pokojninsko in invalidsko zavarovanje, starševsko varstvo in zavarovanje za primer brezposelnosti), delavcu pa izročiti fotokopijo prijave. 


\section{Evalvacija indikatorja (točkovanje):}

\section{Ustrezno (5 točk):}

- Organizacija vsaj 70 \% svojih zaposlenih zaposluje za nedoločen čas.

- Organizacija svoje zaposlene plačuje več kot znaša povprečna mesečna plača na zaposlenega ( $v$ dejavnosti).

\section{Dokazovanje:}

- Organizacija omogoči presojevalcu vpogled v obrazce M1 zaposlenih (Prijava samostojnega podjetnika in delavca v obvezna socialna zavarovanja (obrazec M-1) za s.p. ali Prijava delavca v obvezna socialna zavarovanja za gospodarsko družbo (obrazec M-1)).

- Drugi dokumenti, iz katerih je razviden način zaposlitve (določen čas ali nedoločen čas).

- Izpis bonitetne ocene (S-Bon Ajpes, Bisnode ...) ali dokazilo o številu zaposlenih.

\subsection{Družbena odgovornost do zaposlenih}

$\checkmark$ zadnjih letih postaja družbena odgovornost podjetij vse pomembnejša tematika svetovnega gospodarstva. Družbeno odgovorno podjetje lahko deluje na veliko področjih: družbena odgovornost do zaposlenih, okolja, kupcev, države, skupnosti, konkurentov. Družbeno odgovorno ravnanje se torej tiče vseh deležnikov, ki so v kakršni koli interakciji s podjetjem.

V našem primeru se bomo osredotočili na družbeno odgovornost do zaposlenih. V vsakem podjetju so znanje, izkušnje in motivacija zaposlenih izrednega pomena. Podjetja naj bi namenjala veliko pozornosti izbiri ustreznih kadrov, izobraževanju, osebnostnemu in strokovnemu razvoju delavcev in ustvarjanju pozitivne klime. Z namenom spodbujanja in razvijanja družbeno odgovornega ravnanja podjetij obstaja več različnih certifikatov. Za standarde družbene odgovornosti se podjetja odločajo sama. Razlog za to je želja po dobrem odnosu z zaposlenimi ali pa konkurenčna prednost, ki jo pridobijo s tem standardom.

Primeri certifikatov, ki se nanašajo na družbeno odgovornost podjetij:

1. SA $\mathbf{8 0 0 0}$ (Standard Social Accountability) je mednarodni standard na področju dela in pravic delavcev, ki obsega osem socialnih prvin: delovni čas, plačila, zdravje in varnost, delo otrok, prisilno delo, pravico do kolektivnih pogajanj, zapostavljanje, disciplinske ukrepe. Skratka, obsega razvoj in presojanje sistemov vodenja, ki podpirajo družbeno sprejemljive delovne prakse in prinašajo korist celotni nabavni verigi. 
2. ISO $\mathbf{2 6 0 0 0}$ je mednarodni standard, ki se nanaša na družbeno odgovornost podjetja, izda pa ga mednarodna organizacija ISO (International Organization for Standardization). Standard se uporablja za vse vrste organizacij, ne glede na njihovo velikost, dejavnost ali lokacijo. V primerjavi s standardom SA8000 zajema poleg družbenih vidikov še ekonomske in okoljske vidike poslovanja.

3. OHSAS $\mathbf{1 8 0 0 1}$ opisuje sistem vodenja varnosti in zdravja pri delu, oziroma opredeljuje zahteve v zvezi s sistemi vodenja poklicnega zdravja. Tako lahko podjetja lažje obvladujejo varnostna tveganja in povečujejo učinkovitost svojega delovanja. Organizacija z uvedenim standardom OHSAS 18001 izkazuje skladnost delovanja s predpisi in zahtevami na področju varnosti in zdravja pri delu ter s tem povečuje svoj ugled v javnosti.

4. Certifikat »Družini prijazno podjetje« predstavlja družbeno odgovoren princip upravljanja organizacije. Zagotavlja kratkoročne in dolgoročne pozitivne učinke usklajevanja poklicnega in zasebnega življenja zaposlenih. Pozitivni ekonomski učinki se kažejo v zmanjšanju fluktuacij, bolniških odsotnosti, nege, števila nezgod ter zvečanju zadovoljstva, motivacije in pripadnosti zaposlenih.

5. Certifikat »Družbeno odgovorno podjetje« je analitično - svetovalni postopek, ki temelji na družbeno odgovornem principu upravljanja podjetja. Temelji na smernicah za družbeno odgovornost standarda ISO 26000 ter indikatorjev GRI (Global Reporting Initiative). Podjetjem pomaga pri razumevanju in vpeljavi družbene odgovornosti $\vee$ poslovanje. Certifikat je primeren za podjetja in organizacije ne glede na velikost, pravno obliko in panogo poslovanja.

\section{Evalvacija indikatorja (točkovanje): Ustrezno (3 točke):}

Organizacija ima vsaj enega od naštetih certifikatov.

\section{Dokazila:}

Poleg zgoraj navedenih certifikatov štejejo za ustrezne tudi vsi ostali certifikati, ki se nanašajo na družbeno odgovornost podjetja. Podjetje posreduje skenirane originalne certifikate, strokovna ekipa pa bo preverjala njihovo ustreznost in veljavnost.

\subsection{Zaposlovanje invalidov}

V evropskih državah, kjer je trg dela že vzpostavljen, so za zaščito brezposelnih invalidov, poleg drugih ukrepov za izenačevanje možnosti zaposlovanja, uvedli tudi zakonsko obvezno zaposlovanje invalidov ali kvotni sistem. Gre za pozitivni ukrep države, s katerim se delodajalcem naloži, da določen delež delovnih mest namenijo invalidom oziroma gre za način obveznega zaposlovanja invalidov (Uršič 1995, Presen 2003, Presen 2004). 


\section{Moj Gozdar}

Kvotni sistem zaposlovanja invalidov je bil v Sloveniji zakonsko uveden s sprejemom Zakona o zaposlitveni rehabilitaciji in zaposlovanju invalidov ( $v$ nadaljevanju ZZRZI) leta 2004 in v celoti uveljavljen leta 2006. Določa predpisano število invalidov (med 2 in 6 odstotkov vseh zaposlenih), ki jih mora zaposliti delodajalec glede na dejavnost, ki jo opravlja, in skupno število vseh zaposlenih (Arih, 2016).

Uredba o določitvi kvote zaposlovanja invalidov se določa v naslednjih procentih: 2\% kvota: finančno posredništvo, dejavnost javne uprave in obrambe, obvezno socialno zavarovanje in izobraževanje; 3\% kvota: poslovanje z nepremičninami, najem in poslovne storitve; 4\% kvota: trgovina, popravila motornih vozil in izdelkov široke porabe in druge javne, skupne in osebne storitvene dejavnosti; 5\% kvota: promet, skladiščenje in zveze, zdravstvo ter socialno varstvo; 6\% kvota: kmetijstvo, lov, gozdarstvo; ribištvo in ribolovne storitve, rudarstvo, predelovalna dejavnost, oskrba z elektriko, energijo, plinom in vodo, gradbeništvo in gostinstvo.

Delodajalec ima na izbiro tri načine za izpolnjevanje kvote:

- zaposli predpisano število invalidov,

- sklene pogodbo o poslovnem sodelovanju z invalidskim podjetjem oziroma z zaposlitvenim centrom (nadomestna izpolnitev kvote),

- plača prispevek za spodbujanje zaposlovanja invalidov (v višini 70 \% minimalne plače/veljavne na dan obračuna) (Erbežnik 2007).

\section{Oprostitev plačila prispevkov za pokojninsko in invalidsko zavarovanje je} spodbuda, ki jo lahko uveljavlja delodajalec, in sicer le za tiste invalide, ki jih delodajalec zaposluje nad predpisano kvoto. Poleg tega invalidnost teh invalidov ne sme biti posledica poškodbe pri delu ali poklicne bolezni pri tem delodajalcu. To pravico lahko pri Skladu uveljavljajo tudi delodajalci, ki zaposlujejo manj kot 20 delavcev in zaposlujejo invalide, in samozaposleni invalidi (Arih, 2016). Oprostitev plačila prispevkov PIZ po odločbi Sklada velja za ves čas preseganja kvote (Kos 2010, 20-21).

Nagrado za preseganje kvote lahko uveljavlja delodajalec, ki zaposluje invalide nad predpisano kvoto, in tisti delodajalec, ki zaposluje invalide, če zaposluje manj kot 20 delavcev, katerih invalidnost ni posledica poškodb pri delu ali poklicne bolezni pri tem delodajalcu (Arih, 2016). Nagrada za preseganje kvote je v višini 20 \% minimalne plače na mesec za vsakega zaposlenega invalida nad predpisano kvoto. Sklad prične izplačevati nagrado v 30 dneh od prejema zahtevka ali najpozneje $\vee 90$ dneh od pravnomočnosti odločbe, ki priznava pravico do nagrade. Čas prejemanja nagrade na podlagi odločbe je največ 12 zaporednih mesecev (Uredba o določitvi kvote za zaposlovanje invalidov). 


\section{Evalvacija indikatorja (točkovanje):}

\section{Moj Gozdar}

\section{Ustrezno (2 točke):}

Organizacija, ki je sposobna dokazati, da zaposluje invalide nad predpisano kvoto, dosega kriterije indikatorja.

\section{Dokazovanje:}

Podjetje posreduje (kopije):

- Odločbo, s katero je delodajalec upravičen do nagrade za vsak mesec, ko ima zaposlene invalide nad predpisano kvoto. Odločbo izda Javni štipendijski, razvojni, invalidski in preživninski sklad RS.

- Potrdila o plačilu prispevka za spodbujanje zaposlovanja invalidov (Invalidski sklad - Javni štipendijski, razvojni, invalidski in preživninski sklad RS).

- Pogodbo o sodelovanju z invalidskim podjetjem oz. zaposlitvenim centrom in skenirane račune (ali dokazilo o plačilu).

- Ali odločbo Zavoda za pokojninsko in invalidsko zavarovanje Slovenije (iz katere je razvidno, da zaposluje invalide).

\subsection{Certifikati FSC/PEFC}

Z namenom spodbujanja trajnega gospodarjenja z gozdovi so se na pobudo okoljevarstvenih organizacij začele oblikovati različne mednarodne sheme certificiranja gozdov. Globalno je oblikovanih več različnih sistemov certificiranja gozdov in sledenja lesa. Danes je po svetu uveljavljenih več kot petdeset certifikacijskih shem. Na evropskem trgu sta danes najbolj znana razširjena sistema FSC (Forest Stewardship Council) in PEFC (Programme for the Endorsement of Forest Certification).

Certifikacijske sheme vključujejo splošen prikaz mednarodno sprejetih standardov za trajnostno gospodarjenje (načela, kriterije, indikatorje), navodila oziroma zahteve za certifikacijo, postopke akreditacije neodvisnega organa, presojo trajnostnega gospodarjenja s certificiranimi gozdovi in promocijo sonaravnega gospodarjenja.

Pridobitev certifikatov postaja zelo pomemben pogoj uspešnega delovanja gozdnolesne industrije. Brez ustreznih certifikatov so možnosti za izvažanje surovin in izdelkov na tuja tržišča manjše, saj so kupci izdelkov iz lesa vedno bolj okoljsko ozaveščeni. Podjetja, ki imajo certifikat, pridobijo na ugledu in si tako olajšajo dostop na nove trge.

FSC (Forest Stewardship Council) je mednarodna in neprofitna organizacija, ki promovira trajnostno, ekonomsko sprejemljivo in socialno pravično gospodarjenje. Izdaja certifikate za gozdove in izdelke, pri katerih se upoštevajo zahtevana načela organizacije. Certifikat je namenjen predvsem večjim lastnikom gozdov in podjetjem. 
PEFC (Programme for the Endorsement of Forest Certification) je mednarodna nevladna in neprofitna organizacija, ki spodbuja trajnostno gospodarjenje z gozdovi. Organizacija podpira nacionalne sheme certifikacije gozdov, ki svoje zahteve prilagajajo lokalnim specifikam. Certifikat PEFC je namenjen predvsem lastnikom manjših gozdov, ki trajnostno gospodarijo z gozdom.

Certificiranje gozdov v skladu s standardoma FSC ali PEFC je popolnoma prostovoljno dejanje lastnikov gozdov in upravljalcev. Veljavnost certifikata je pet let. Za podaljšanje veljavnosti certifikata se mora opraviti ponovna presoja trajnostnega gospodarjenja s strani organa. Certifikacijski organ pa mora vsaj enkrat letno izvajati kontrolo primernosti trajnostnega gospodarjenja.

\section{Evalvacija indikatorja (točkovanje): Ustrezno (5 točk): \\ Organizacija ima pridobljen certifikat FSC ali PEFC.}

\section{Dokazila:}

Organizacija posreduje identifikacijski številki za omenjena certifikata, na podlagi katerih se bo preverjala njihova veljavnost.

\subsection{Varovanje sestoja, gozdnih tal, vodotokov in infrastrukture}

Sodobna tehnologija je bistvenega pomena za trajnostno upravljanje z gozdovi. Pri gospodarjenju je treba skrbeti za odpravljanje oz. zmanjševanje negativnih vplivov na okolje in po drugi strani za ekonomsko učinkovite načine gospodarjenja z naravnimi viri. Dandanes je sodobna tehnologija za spravilo lesa opremljena z naprednimi elektronskimi sistemi (GPS, GIS, IKT...), ki so lahko odlično uporabljeni za načrtovanje, spremljanje in nadzor gospodarjenja z naravnimi viri. Okoljski vidiki pridobivanja lesa so neposredno povezani z uporabljanimi tehnologijami. Vsaka tehnologija ima namreč določen in značilen vpliv na gozdni prostor, pri čemer je obseg poškodb odvisen od več dejavnikov. Ob pripravi strokovnih podlag za okoljski vidik pri izboru tehnologij je treba upoštevati tudi vidike okoljsko učinkovitega sistema gospodarjenja z naravnimi viri. V sklopu mednarodnega projekta EcoWood sedmega okvirnega programa (Owende et al., 2002) so upoštevali naslednje vidike:

- zmanjševanje oz. odpravljanje motenj tal (površina tal, korenine, zbijanje tal, plasti inverzije, erozija...), ki običajno nastanejo pri gospodarjenju z naravnimi viri,

- $\quad$ v primeru redčenj v največji možni meri reducirati poškodbe na preostalih drevesih v sestoju,

- zmanjševanje oz. odpravljanje škode na vodotokih,

- izboljševanje učinkovitosti oz. produktivnosti gospodarjenja z naravnimi viri, 


\section{Moj Gozdar}

- ter zagotavljanje varnosti ljudi, ki so neposredno vpleteni v procese gospodarjenje z naravnimi viri, in sicer z zagotavljanjem usposobljenih operaterjev pri sečnji in spravilu.

Izsledki raziskav v literaturi nakazujejo, da je izbrana tehnologija (mehanizacija) zgolj segment v celotnem mozaiku okoljske problematike. To pa pomeni, da je vpliv sečnospravilnih strojev na okolje odvisen od več dejavnikov. To so predvsem tip tal ter ustreznost izbrane tehnologije določenemu tipu tal, infrastruktura oz. odprtost gozdov s prometnicami (primarnimi, sekundarnimi in terciarnimi) ter letni čas, $v$ katerem potekajo dela (npr. strojna sečnja ali spravilo na slabo stabilnih tleh je mogoča le poleti, ko so tla razmeroma suha, ali pozimi, ko je površina tal zmrznjena (Owende et al., 2002).

\section{Klasifikacija poškodb}

Negativni vplivi pri gospodarjenju z naravnimi viri so:

- Oblikovanje kolesnic in poškodbe koreninskega sistema: ponavljajoče vožnje težke mehanizacije po isti poti vodijo k oblikovanju kolesnic. V skrajnih rastiščnih primerih oz. ob uporabi neprimerne mehanizacije lahko strukturo tal tako spremenimo, da nastane blato.

- Zbijanje tal: je posledica tlačenja tal, pri čemer se zmanjša prostornina tal, makropore in količina zraka v tleh (Mrhar, 2001). Te poškodbe vodijo do zmanjšane sposobnosti pronicanja vode v tla. V primeru oblikovanja kolesnic oz. kanalov pa je spremenjen tudi pretok površinske vode (voda hitreje odteče $\checkmark$ vodotoke). Zato sta pomembni uporaba ustrezne mehanizacije in ustrezna sanacija kolesnic po končani gozdni proizvodnji.

- Površinske motnje: nastajajo ob zdrsu med kolesi in tlemi pri zagotavljanju vlečne sile. Obsežnost zdrsa in same površinske motnje je odvisna od več dejavnikov, kot so stanje tal, masa vozila, tip pnevmatik (širina in profil), pritisk $\checkmark$ pnevmatikah, potrebna vlečna sila in drugi parametri tal in vozila.

- Poškodbe sestoja: nastajajo pri vsakokratnem posegu v sestoj zaradi sečnje dreves in predvsem zaradi spravila sortimentov po brezpotju do prve prometnice. Obseg poškodb je odvisen od številnih dejavnikov. Poškodbe v sestojih se kopičijo, da so pri vsakokratnem naslednjem poseku poškodovana povsem nova drevesa (Košir 2000), zato je treba stremeti k tehnološkim rešitvam za zmanjševanje poškodb na sestoju.

- Erozija: gozdna proizvodnja lahko pospeši izpiranje tal ter druge erozijske pojave še posebej v hribovitih območjih z različnimi procesi, kot so:

- površinska erozija na vlakah

- izpiranje tal ob prekomerni odstranitvi vegetacije

- povečano površinsko odtekanje zaradi prekomerne odstranitve gozdne vegetacije

○ ter drugi 
Treba se je zavzemati za:

- zmanjševanje oz. odpravljanje motenj tal (površine tal, korenin, zbijanje tal, plasti inverzije, erozija ...), ki navadno nastanejo pri gospodarjenju z naravnimi viri,

- $\quad$ v primeru redčenj v največji možni reducirati poškodbe na preostalih drevesih v sestoju,

- zmanjševanje oz. odpravljanje škode na vodotokih,

- izboljševanje učinkovitosti oz. produktivnosti gospodarjenja z naravnimi viri.

Posamične tehnične rešitve za povečanje vlečnih sposobnosti gozdarske mehanizacije in zmanjševanje obremenitev tal oz. koreninskega sistema so že poznani sistemi za povečanje vlečnih sposobnosti:

- razporeditev mas na več osi,

- hidrostatski pogon,

- prestavljanje pod obremenitvijo,

- širše pnevmatike z ustreznimi profili,

- centralno uravnavanje tlaka v pnevmatikah,

- opremljenost z nizkotlačnimi pnevmatikami,

- povečana širina naležnega profila pnevmatik,

- pravilna izbira namenskih (mokra tla, nakloni, led in sneg) goseničnih trakov oz. tako imenovanih »boogie-gosenic«,

- nameščanje alternativnih goseničnih nastavkov na goseničnih strojih (»streetrubber«) ali goseničnih koles,

- uporaba pomožnega pogonskega vitla pri delu na večjih naklonih in na občutljivih tleh z veliko verjetnostjo zdrsa pogonskih koles.

\section{Okoljska primernost strojev in ergonomski vidik}

Posredna povezava z okoljsko primernostjo stroja je tudi njegov vpliv na človeka in delovne razmere - ergonomski vidik. Zmanjševanje obremenitev s hrupom in tresenjem, ki so v procesu pridobivanja lesa izraziti, ni povezano samo z uporabo osebne varovalne opreme, marveč tudi z izbiro mehanizacije z nižjo stopnjo teh obremenitev. Tehnični ukrep v okviru ergonomskega vidika je npr. pri žičniškem spravilu uporaba lažjih sintetičnih vrvi (sidranje).

\section{Meje vrednosti dimenzij traktorjev}

Traktorji kolesniki za delo v gozdu morajo biti primernih dimenzij (moč motorja, mere in mase), da zagotavljajo zadostno vlečno silo, stabilnost traktorja pri uporabi vitla in sami vleki in pri tem hkrati zagotavljajo čim boljšo okoljsko sprejemljivost, oz. so njihove dimenzije v okviru sprejemljivosti za delo v gozdu. Traktorji manjših, a še vedno zadostnih dimenzij so okoljsko sprejemljivejši, saj zahtevajo manjše dimenzije vlak/cest in jih hkrati manj obremenjujejo. Pri traktorjih je ponudba glede na dimenzije 
(mere, mase, moči) izjemno široka, za določena dela pa se le te gibljejo v določenih okvirih. Za učinkovito delo $v$ gozdu so smiselne minimalne dimenzije na eni in omejitev maksimalnih dimenzij na drugi strani, da je traktor skupaj z nameščenim priključnim strojem še sprejemljiv za delo na omejenem prostoru v gozdu.

\section{Razmerje med močjo traktorja in nazivno vlečno silo vitla (indeks vlečne sile)}

Za učinkovito in okoljsko čim bolj sprejemljivo delo v gozdu morata biti traktor in vitel medsebojno dimenzijsko usklajena. Dimenzije traktorja morajo biti $v$ ustreznem razmerju z nazivno vlečno silo vitla. Pri uporabi gozdarskih traktorskih prikolic je kritična točka, gledano z okoljskega vidika, izvoz traktorja s prikolico iz gozda, posebej $\checkmark$ slabših voznih razmerah, zato lahko pri prikolicah s pogonom lahko pričakujemo manj poškodb tal zaradi manjšega zdrsa pogonskih koles traktorja. Pri zbiranju lesa z vitlom ob uporabi daljinskega krmiljenja vitla, poleg učinkovitejšega in lažjega dela, zagotavljamo boljši nadzor med zbiranjem bremena (gozdnih sortimentov) in tako manjše poškodbe gozdnega mladja in še stoječega drevja. Praviloma mora organizacija pri nakupu mehanizacije upoštevati priporočila proizvajalca, kakšna dimenzija traktorja (praviloma izražena v moči motorja) je najbolj priporočljiva za konkretni vitel ali prikolico.

\section{Gozdarska nadgradnja traktorjev za delo v gozdu}

Gozdarska nadgradnja mora biti zasnovana ob upoštevanju zahtev za učinkovito delo $\checkmark$ gozdu pri spravilu lesa (naletno odrivna deska), zagotavljanju varnosti pri delu v gozdu (ojačitev in zaščita kabine) in preprečevanju poškodb stroja, ki bi lahko imela tudi negativne vplive na okolje (zaščiteno podvozje). Izdelana mora biti v skladu s predpisi in standardi s področja varnosti strojev.

\section{Okoljsko usmerjeno načrtovanje in opravljanje gozdarskih storitev}

$\checkmark$ preteklosti je bilo v Avstriji nekaj poskusov vrednotenja ponudnikov del na podlagi pregleda delovišča po opravljeni storitvi po načelu 'Bonus-Malus' (Ofner, 2005), a se tak pristop ni uveljavil v širšem obsegu. Sistem zagotavljanja kakovosti dela je bistven predpogoj za povečanje sprejemljivosti izkoriščanja gozdov s strojno sečnjo. Pri tem je treba dosegati minimalne zahteve pri pripravi in organizaciji strokovnega dela ter učinkovit nadzor in posledice $v$ primeru odmikov od specifikacij. Osnovna ideja sistema Bonus/Malus je vnaprej dogovorjen način nagrajevanja izvajalca, ki je opravil strojno sečnjo brez večjih negativnih vplivov na sestoj in tla (dvig plačila za 2 \%) oz. način znižanja plačila storitve (za $1 \%$ ) v primeru, da poškodbe presegajo vnaprej dogovorjene standarde.

Na Gozdarskem inštitutu Slovenije so predstavili metodologijo za oblikovanje odločevalnega orodja za izbor ekološko ustrezne tehnologije pri proizvodnji zelenih sekancev, upoštevajoč različne ekološke in tehnološke dejavnike (Triplat in sod., 2016). Gre za tristopenjski metodološki pristop, kjer v prvem koraku opredelimo talne 


\section{Moj Gozdar}

in terenske razmere, $v$ drugem koraku tehnologije ob upoštevanju raznolikosti glede na gospodarske učinke in ekološko primernost, v zadnjem, tretjem koraku, izbranim tehnologijam določimo mesto $v$ odločitveni matriki z upoštevanjem tehnološke in ekološke omejitve posameznih tehnoloških modelov. Odločitvena matrika je skupaj s tehnološkimi modeli pripomoček za izvedbeno načrtovanje procesa pridobivanja lesa in lesne biomase na konkretnih deloviščih. Z njeno uporabo ne dosegamo neposredne racionalizacije proizvodnje, ampak artikuliramo okoljske vidike proizvodnih verig $\vee$ gozdu, zlasti tistih, ki vsebujejo tako pridobivanje lesa kot pridobivanje zelenih sekancev. Odločitvena matrika je namenjena predvsem pripravi dela, a jo je mogoče s pridom uporabiti tudi med izvajanjem del, ko se spremenijo delovne razmere:

- spremenijo se vlažnostne razmere v delovišču,

- pokvaril se je stroj in izbrati je treba nadomestno mehanizacijo,

- zaradi zapolnitve kapacitet se uporabi drug/nepredviden stroj.

\section{Evalvacija indikatorja (točkovanje): Ustrezno (6 točk):}

Organizacija je sposobna dokazati:

investicije v okoljsko primernejše tehnologije (mehanizacijo),

- uporabo sistema za okoljsko usmerjeno načrtovanje in izvedbo gozdarskih storitev.

\section{Dokazovanje:}

- homologacijski dokument (potrdilo o skladnosti) tudi za neregistrirane traktorje (se priloži pri zahtevku za izplačilo),

- dokazilo o vzpostavitvi sistema skrbnega ravnanja in varovanja sestoja, tal in gozdne infrastrukture.

\subsection{Zmanjšanje emisij škodljivih snovi v izpušnih plinih pri strojih}

Promet je zaradi lastne porabe energije glavni povzročitelj pritiskov na okolje. Potniški in tovorni promet porabi veliko energije, sčimer povzroča izpuste toplogrednih plinov in onesnaževal zraka. Med negativne vplive prometa na okolje štejemo tudi spremembe rabe zemljišč zaradi gradnje prometne infrastrukture, nastajanje odpadnih motornih vozil in drugih, tudi nevarnih odpadkov, hrup, izlive nevarnih snovi $\checkmark$ okolje ob prometnih nesrečah in okvarah vozil ter motenje naravnih habitatov prostoživečih živali (Arso, 2009). Vse več tovora je prepeljanega, prevozne razdalje so vse daljše, prevozi vse pogostejši. Vse večji delež prepeljanega tovora na transportnem tržišču je pripadlo cestnemu tovornemu prometu. Vse to je pripeljalo do vse večjih emisij CO² in drugih škodljivih snovi. Poraba energentov v transportu je vse večja, prav tako posledično tudi emisije toplogrednih plinov. 


\section{Moj Gozdar}

Zaradi tehnoloških izboljšav pri vozilih je izkoristek rabe energije vse boljši in so izpusti vse manjši. Tako lahko rečemo, da postaja tudi cestni prevoz vse bolj ekološko sprejemljiv. To je posledica vse bolj strogih ekoloških standardov, namenjenih različnim načinom prevoza. Kvaliteta zraka in okolja na splošno v evropskih mestih še vedno ne ustreza postavljenim normam, ki izhajajo iz zahtev Evropske unije, glede glavnih negativnih vplivov na zdravje ljudi.

Obnavljanje voznega parka pozitivno vpliva na zmanjševanje izpustov dušikovih oksidov. Novi motorji in nova vozila na splošno, ki prihajajo na trg v zadnjem času, vse manj onesnažujejo okolje, prav tako je izboljšana tudi učinkovitost porabe goriva. To je pomembno z ekološkega vidika, ne moremo pa zanemariti tudi vpliva na zmanjšanje stroškov. Stroški goriva namreč v zadnjem času postajajo zelo pomemben vidik stroškov vsakega podjetja, ne samo transportnega. (Sušnik, 2008).

Z Zakonom o varnosti cestnega prometa so bile v naš pravni red prenesene obveznosti EU, ki uvajajo v cestni promet zahteve varstva okolja glede izpustov izpušnih plinov, prevozov nevarnega blaga, omejevanja hitrosti, ravnanja z izrabljenimi vozili. Z vidika varovanja okolja je pomembno tudi ugotavljanje skladnosti cestnih vozil, ki je del evropskega sistema preverjanja vozil. Ta omogoča, da se dajejo v promet samo vozila, ki ustrezajo veljavnim predpisom. Za tiste kategorije vozil, ki jih zajemajo usklajeni predpisi (osebna vozila, motorna kolesa, nekateri traktorji), se pregled skladnosti s predpisi opravi samo enkrat v eni od držav EU (ES-homologacija) in nato velja v celotni EU.

Mehanizacija za sečnjo in spravilo mora zagotavljati učinkovito, ekonomično in varno delo ob upoštevanju vseh okoljskih vidikov. Pri strojih, gnanih na motor z notranjim izgorevanjem, je treba stremeti k čim manjšim emisijam škodljivih snovi v izpušnih plinih. Tako morajo motorji izpolnjevati mejne vrednosti, določene v direktivi 97/68 ES in njenih spremembah in implementacijah $v$ nacionalno zakonodajo.

\section{Evalvacija indikatorja (točkovanje): Ustrezno (3 točke):}

- $50 \%$ strojev in vozil v podjetju ni starejših od štirih let.

\section{Delno ustrezno (1,5 točke):}

- 50 \% strojev in vozil v podjetju ni starejših od šestih let.

\section{Dokazovanje:}

- Fotokopija homologacije za neregistrirana vozila

- Številka prometnega dovoljenja in registrska številka 


\subsection{Uporaba biorazgradljivih olj}

Moj Gozdar

$\checkmark$ proizvodnji maziv dandanes vse bolj v ospredje prihajajo vprašanja o njihovi strupenosti in biološki razgradljivosti. Mineralna maziva so težko razgradljiva in strupena, onesnaževanje z mazili pa vodi v resne ekološke probleme. Tako je biološko razgradljiva olja smiselno uporabiti na področjih, kjer odpadnih maziv ni mogoče zbrati in ponovno uporabiti. Prav tako je uporaba okolju prilagojenih maziv smiselna tam, kjer obstaja velika možnost nenamernega razlitja olja in posledično onesnaženje okolja. V primeru razlitja mineralnega olja na travnati površini pride do tako imenovanega požiga nadzemnega dela rastline. Razlitje biološko razgradljivega olja pa povzroči le razbarvanje zelenega dela rastline, podzemni del pa ostane nepoškodovan. Rastlina se $v$ roku desetih dni popolnoma obnovi in običajno ne zaznamo nezaželenih trajnih posledic.

Sistem, kjer odpadnih maziv ni mogoče ponovno zbrati, lahko opredelimo tudi kot sistem s popolnimi izgubami. $\vee$ gozdarstvu se s to problematiko srečujemo pri delu $\mathrm{v}$ gozdu z verižno žago, konkretno pri mazanju letve motorne žage. $V$ tem primeru maziva končajo direktno v okolju, zato vse več držav sprejema zakonske predpise, s katerimi se zahteva uporaba biorazgradljivih olj.

V Sloveniji je z Resolucijo o nacionalnem gozdnem programu (št. 111/07), ki je temeljni dokument s področja gozdarstva, $v$ eni izmed usmeritev poudarjeno spodbujanje uporabe biološko razgradljivih olj za mazanje žagalnih verig na vodovarstvenih območjih. To področje pa konkretno ureja Pravilnik o varstvu gozdov (št. 114/09 in 31/16). Glede opravljanja del v gozdovih v 17 . členu opredeljuje, da stroji in naprave, z izjemo motorne žage, ne smejo puščati oljnih sledi. V območjih s prvo stopnjo poudarjenosti hidrološke funkcije in $v$ predelih zavarovane narave se morajo za mazanje verige pri motornih žagah ter $v$ hidravličnih sistemih strojev in naprav uporabljati biološko razgradljiva olja. Prav tako Uredba o varovalnih gozdovih in gozdovih s posebnim namenom (št. 88/05) v 5. členu opredeljuje, da mora Zavod za gozdove pri gospodarjenju z varovalnimi gozdovi zagotavljati rabo biološko razgradljivih olj pri delu s stroji in napravami.

Zahtevo uporabe biorazgradljivih olj terjajo tudi nekatere mednarodne sheme certificiranja gozdov. Ena izmed takšnih je FSC (Forest Stewardship Council), ki v svojih načelih in merilih zahteva uporabo biorazgradljivih hidravličnih olj in olj za mazanje verig motornih žag. Prav tako predpisuje tehnične rešitve za preprečitev izlitja olj, kot so posoda za zibanje izlitega olja, vpojne krpe itd.

\section{Evalvacija indikatorja (točkovanje): Ustrezno (5 točk):}

Ustreznost indikatorja se določa glede na vrsto registrirane dejavnosti: 
Sečnja z motorno žago:

- Organizacija uporablja biološko razgradljiva olja za mazanje verig motornih žag.

\section{Strojna sečnja:}

- Organizacija uporablja biološko razgradljiva hidravlična olja.

\section{Sečnja z motorno žago in strojna sečnja:}

- Organizacija uporablja biološko razgradljiva olja za mazanje verig motornih žag.

- Organizacija uporablja biološko razgradljiva hidravlična olja.

\section{Dokazila:}

Uporaba biološko razgradljivega olja za mazanje verig motornih žag:

Za $50 \mathrm{~m}^{3}$ posekanega lesa mora organizacija izkazati nakup 1 litra biorazgradljivega olja (npr.: organizacija, ki poroča o letnem obsegu sečnje 4000 m³, priloži račun za 80l biološko razgradljivega olja.).

Dokazilo prikaže v obliki skeniranega računa, s katerega je razviden nakup biološko razgradljivega olja. Dokazilo lahko prikaže tudi v kateri drugi obliki, njeno ustreznost pa bo preveril neodvisni strokovni presojevalec.

\section{Uporaba biološko razgradljivega hidravličnega olja:}

$\mathrm{Na} 100 \mathrm{~m}^{3}$ posekanega lesa mora organizacija prikazati nakup 1,5 litra biorazgradljivega hidravličnega olja (npr.: organizacija, ki poroča o letnem obsegu strojne sečnje $20.000 \mathrm{~m}^{3}$, priloži račun za 300l razgradljivega hidravličnega olja.).

Dokazilo prikaže v obliki skeniranega računa, s katerega je razviden nakup biološko razgradljivega olja. Dokazilo lahko prikaže tudi v kateri drugi obliki, njeno ustreznost pa bo preveril neodvisni strokovni presojevalec.

\subsection{Raba energije iz obnovljivih virov}

Vse vire energije, ki jih zajemamo iz stalnih naravnih procesov (sončno sevanje, vodni tok rek, tokovi morja, zemeljski toplotni tokovi, veter, biomasa), definiramo kot obnovljive vire energije. Ti zaradi vse večje odvisnosti od energije in po drugi strani zmanjševanju zalog fosilnih goriv in povečanju onesnaženosti okolja postajajo vse bolj pomembni. V nasprotju z neobnovljivimi viri (fosilna goriva, kot so premog, nafta, zemeljski plin, jedrska energija) obnovljivi viri energije niso količinsko omejeni. Imenujemo jih čista ali zelena energija, saj pri pridobivanju nimajo škodljivih vplivov na okolje. 
Lesna biomasa je strateško najpomembnejši obnovljivi vir energije v državi, sledita vodna in sončna energija. Poleg navedenih virov pa k povečani porabi štejemo še bioplin ter potenciale energije vetra in geotermalne energije. Slovenija se je na podlagi Direktive 2009/28/ES, izdane s strani Evropskega parlamenta in sveta, zavezala k spodbujanju uporabe energije iz obnovljivih virov. Prav tako je vsaka članica Evropske unije morala sprejeti Nacionalni akcijski načrt za obnovljive vire energije za obdobje 2010-2020. Eden izmed ciljev načrta Sloveniji narekuje, da mora v končni bruto rabi energije do leta 2020 doseči najmanj 25\% delež iz obnovljivih virov.

Izraz zelena elektrika uporabljamo za električno energijo, proizvedeno iz obnovljivih virov energije, ki imajo manj nezaželenih vplivov na okolje kot tradicionalni neobnovljivi viri. Med zeleno elektriko, ki je končnim odjemalcem na voljo pri nas, prevladuje energija, pridobljena iz hidroelektrarn. Na drugem mestu je sončna energija, najmanjši delež pa imajo bioplin, biodizel in plin iz komunalnih čistilnih naprav. Na slovenskem trgu dobavitelji električne energije svojim odjemalcem ponujajo zeleno elektriko pod različnimi imeni. Največkrat gre za izpeljanke zelene ali modre energije oziroma zelene in modre pakete. Za elektriko iz obnovljivih virov je v večini primerov potrebno doplačilo. Večina ponudnikov na trgu navaja, da je dodaten prispevek namenjen spodbujanju raziskav, razvoju, obnovi in gradnji novih zmogljivosti za izkoriščanje obnovljivih virov v Sloveniji. Ali ponudniki električno energijo res dovajajo iz obnovljivih virov, lahko odjemalci preverijo na različne načine. Poleg samega zaupanja do dobavitelja ostajajo še drugi mehanizmi. Skladno z Aktom o načinu določanja in prikazovanja deležev posameznih proizvodnih virov (Uradni list RS, št 22/2016) lahko uporabniki sestavo proizvodnih virov pri proizvodnji vse električne energije, ki jo je dobavitelj dobavil v prejšnjem koledarskem letu, vidijo na zadnji strani računa, ki ga dobijo za električno energijo. Na njem mora biti prikazan tudi odstotek energije iz obnovljivih virov oz. zelene elektrike. Poreklo energije lahko dobavitelji prav tako dokazujejo s potrdili o izvoru in tržnimi zelenimi certifikati, ki jih predložijo odjemalcu.

Trajnostno naravnana podjetja, ki jim je ekološko odgovorno vedenje pomemben dejavnik pri izbiri vira proizvodnje električne energije, imajo sklenjeno pogodbo s ponudnikom, ki zagotavlja zeleno energijo, pridobljeno iz obnovljivih virov.

Samoproizvajalci elektrike so podjetja, ki poleg svoje osnovne dejavnosti proizvajajo še električno energijo ali toplotno energijo v celoti ali delno za lastne potrebe. Lahko so $v$ privatni ali $v$ javni lasti. To področje ureja Uredba o samooskrbi z električno energijo iz obnovljivih virov energije (Uradni list RS, št 97/2015 in 32/2018). S to uredbo se določa ukrep spodbujanja rabe električne energije, pridobljene iz OVE z napravo za samooskrbo, ki je priključena na notranjo nizkonapetostno električno omrežje. Lastnik naprave za samooskrbo ima z dobaviteljem sklenjeno pogodbo o samooskrbi, 
s katero se dogovorita, da se oddana električna energija kompenzira s prevzeto električno energijo v obračunskem obdobju.

Načelu odgovornosti do okoljskih vidikov sledijo podjetja, ki imajo za svoje potrebe deloma ali $v$ celoti zagotovljeno samooskrbo $z$ električno energijo. $V$ primeru viškov električne energije te oddajajo v omrežje.

\section{Evalvacija indikatorja (točkovanje): Ustrezno (2 točki):}

Organizacija pridobi vse točke, če izpolnjuje enega izmed naslednjih navedenih pogojev:

- zagotavlja rabo energije iz obnovljivih virov,

- ima urejen samooskrbni sistem z energijo.

\section{Dokazila:}

Za doseganje vseh točk predstavljenega indikatorja mora organizacija zagotavljati rabo energije iz obnovljivih virov ali pa mora imeti urejen samooskrbni sistem z energijo.

Kot dokazilo za zagotavljanje energije iz OVE organizacija priloži ustrezno skenirano dokumentacijo (npr. Pogodbo o oskrbi z energijo; račun za električno energijo), na katerem je razviden delež energije, pridobljen iz OVE.

Kot dokazilo za urejen samooskrbni sistem z električno energijo ustreza skenirano potrdilo (npr. Pogodba o samooskrbi, ki jo ima sklenjeno z dobaviteljem. »Pogodba o samooskrbi« je pogodba med dobaviteljem in lastnikom naprave za samooskrbo, s katero se dogovorita, da se oddana električna energija (kWh) kompenzira s prevzeto električno energijo (kWh) v obračunskem obdobju.)

\subsection{Sistem ravnanja z okoljem ISO 14001}

Okoljska problematika postaja $\vee$ zadnjih letih vse bolj pomembna in njeno upoštevanje pomembna konkurenčna prednost podjetij ter pogoj za njihovo učinkovito poslovanje. Standard, ki določa zahteve za sistem ravnanja z okoljem za proizvodne ali storitvene dejavnosti, je ISO 14001. Namenjen je podjetjem, ki želijo vpeljati, ohranjati ali izboljšati sistem ravnanja z okoljem, poslovati v skladu s svojo okoljsko politiko, pridobiti certifikat od ustrezne organizacije in uskladiti sistem ravnanja z okoljem zahtevam standarda (Skralovnik, 2016). Nanaša se na tiste prepoznane okoljske vidike, na katere ima organizacija vpliv in jih lahko obvladuje. Obsega izpolnjevanje zakonskih zahtev, učinkovito izkoriščanje virov ter preprečevanje onesnaževanja okolja (ISO ..., 2019). Je eno najpomembnejših orodij v odnosu do okolja, ki ga uporabljajo organizacije in korporacije po vsem svetu.

Osnovna načela, na katerih temelji sistem ravnanja z okoljem ISO 14001, so (ISO ..., 2019):

zavezanost in politika, 
- načrtovanje,

- izvajanje,

- spremljanje, merjenje in ocenjevanje,

- pregled in izboljševanje.

Najpomembnejši deli standarda zajemajo določitev in ovrednotenje pomembnih vplivov dejavnosti organizacije na okolje (ob upoštevanju zahtev okoljske zakonodaje), zasnovo in obravnavo okoljske politike podjetja, pripravo načrtov in postopkov za zmanjšanje oz. odpravo negativnih vplivov, pregled in dopolnitev sistema upravljanja z okoljem ter odzivanje na zahteve in pričakovanja poslovnih partnerjev organizacije, lastnikov oz. ustanoviteljev organizacije in druge zainteresirane javnosti (Zupanc, 2008). Velik pomen je na nenehni izboljšavi okoljske učinkovitosti. Organizacija naj bi postopno zmanjševala emisije in druge izpuste, uporabo nevarnih snovi ter količino svojih odpadkov. Poleg tega naj bi razvila strategijo notranjega in zunanjega komuniciranja. Obseg uporabe je odvisen od okoljske politike organizacije, narave njenih dejavnosti, proizvodov in storitev, lokacije in razmer v katerih deluje (Fabčič, 2010).

Pomembne pridobitve z uvedbo standarda, ki prispevajo k ugledu podjetja (Strašek, 1998, cit. po Šircelj, 2006):

- sistemsko obvladovani varčevalni ukrepi in neposredno znižani stroški poslovanja,

- povečano zaupanje javnosti, strank in poslovnih partnerjev,

- večje zanimanje vlagateljev,

- izboljšane delovne razmere,

- nižje zavarovalne premije,

- strateška prednost in izboljšan konkurenčni položaj na trgu,

- izboljšane metode vodenja procesov,

- upoštevanje okoljske zakonodaje na področju varstva okolja,

- manjša poraba energije,

- smotrna izraba naravnih virov in surovin,

- zmanjševanje odpadkov,

- zmanjšanje tveganja ekoloških nesreč,

- urejena okoljska dokumentacija,

- prednost pri izbiranju primernih dobaviteljev.

\section{Evalvacija indikatorja (točkovanje):}

\section{Ustrezno (4 točke):}

- Organizacija ima certifikat ISO 14001.

\section{Dokazilo:}

Organizacija predloži certifikat skladnosti - skeniran dokument. 


\subsection{Upravljanje z nevarnimi odpadki}

Tako kot pri drugih dejavnostih tudi pri gospodarjenju z gozdom nastajajo odpadki. Procesi sečnje v državah EU letno ustvarijo med 25.000 in 30.000 ton odpadkov, od katerih je okoli $70 \%$ nevarnih in so nevarni za ljudi in okolje. Gre predvsem za odpadna olja, baterije in akumulatorje, pnevmatike, odpadno embalažo ter električno in elektronsko opremo. Tudi manjša prazna embalaža, npr. sprej za označevanje dreves, sečnih poti ipd., navadno vsebuje ostanke vnetljivih plinov in je zato nevaren odpadek. Pri takih odpadkih, ki so sicer majhni, je bolj kot velikost treba upoštevati njihovo škodljivost. Odvržena maziva lahko onesnažijo vodna zajetja za več sto let.

$\checkmark$ primerjavi z drugimi dejavnostmi pa odpadki, ki so posledica gospodarjenja v gozdu, pogosto nastanejo razpršeno in daleč od omrežij zbiranja. Težko jih je jasno določiti, pravilno skladiščiti in ustrezno odstraniti. Novejši, večji in učinkovitejši stroji običajno proizvedejo tudi večje količine odpadkov. Tako npr. motorna žaga v primerjavi s traktorjem ali harvesterjem letno povzroči zelo malo odpadkov (predvsem vodniki in verige), vendar je tudi produktivnost takega dela bistveno manjša. V Evropi pa je čutiti trend k povečanju mehanizacije težjega dela, in posledično nastaja več odpadkov.

To področje v Sloveniji urejajo Zakon o varstvu okolja, Uredba o odpadkih in drugi veljavni predpisi (MOP).

Uredba o odpadkih z namenom varstva okolja in varovanja človekovega zdravja določa pravila ravnanja in druge pogoje za preprečevanje ali zmanjševanje škodljivih vplivov nastajanja odpadkov in ravnanja z njimi ter zmanjševanje celotnega vpliva uporabe naravnih virov in izboljšanje učinkovitosti uporabe naravnih virov. Z odpadki je treba ravnati tako, da ni ogroženo človekovo zdravje in ne škodijo okolju: da ravnanje ne predstavlja tveganja za vode, zrak, tla, rastline in živali; ne povzroča čezmernega obremenjevanja s hrupom in neprijetnimi vonjavami; ne povzroča škodljivih vplivov na območja, na katerih je predpisan poseben režim v skladu s predpisi, ki urejajo ohranjanje narave, ali predpisi, ki urejajo varovanje virov pitne vode; ne povzroča škodljivih vplivov na krajino ali območja, na katerih je predpisan poseben režim v skladu s predpisi, ki urejajo varstvo kulturne dediščine.

Odpadke je prepovedano puščati v okolju, jih odmetavati ali z njimi nenadzorovano ravnati. Še posebno problematični so tako imenovani nevarni odpadki. Nevarni odpadek je odpadek, ki je zaradi ene ali več nevarnih lastnosti s predpisom uvrščen med nevarne odpadke (Zakon o varstvu okolja).

\begin{tabular}{|l|}
\hline Nevarni odpadki, ki nastanejo pri gospodarjenju z gozdom \\
\hline Aerosoli, barve \\
\hline Odpadna električna in elektronska oprema \\
\hline Umazane posode in oprema \\
\hline
\end{tabular}


Moj Gozdar

\begin{tabular}{|l|}
\hline Odpadna olja (hidravlična in motorna) \\
\hline Različne tekočine (zavorna in hladilna tekočina) \\
\hline Baterije in akumulatorji \\
\hline Topila in detergenti \\
\hline Pesticidi \\
\hline
\end{tabular}

Pri nepravilnem ravnanju s katerimikoli odpadki, posebno pa še z nevarnimi, lahko pride do nezaželenih vplivov na okolje; npr. izpusti v zrak, površinske in podzemne vode, tla. Poleg kratkoročnih negativnih vplivov na okolje je treba upoštevati tudi možne dolgoročne vplive. To je tudi eden izmed razlogov, zakaj je pomembno, da se tok odpadkov preusmeri od odlaganja v druge postopke obdelave.

\section{Odpadna olja}

Najpogosteje prihaja do izlivov hidravličnih olj pri okvarah cevovodov, puščanju hidravličnih sistemov (nakladalne naprave...), izlivov motornih in mazalnih olj pri strojelomih, izgorevanju in izhlapevanju protikorozijskih zaščitnih sredstev ter olj za mazanje dvotaktnih motorjev (motorne žage), izrabi in spiranju masti in drugem. Nezanemarljiv je pomen uporabe mineralnih olj pri odprtih mazalnih sistemih. Podrobneje je ravnanje z odpadnimi olji opisano v Uredbi o odpadnih oljih (Uradni list RS, št. 24/12). Odpadna olja je $v$ splošnem prepovedano puščati $v$ zabojnikih za zbiranje komunalnih odpadkov, jih odmetavati ali zlivati na tla oziroma v površinske in podzemne vode. Treba jih je oddati na za to določenih mestih (zbirni centri). Nadzor nad uresničevanjem te uredbe opravljajo inšpektorji, pristojni za varstvo okolja. Prekrški se kaznujejo z denarno kaznijo.

\section{FSC in PEFC}

Zahteve glede ravnanja z odpadki postavljata tudi certifikata FSC in PEFC. Prepovedano je vsakršno odlaganje odpadkov $\vee$ gozd, ki zmanjšujejo rastnost ali rodovitnost rastišča, stabilnost ali trajnost gozda ali ogroža njegove funkcije, obstoj ali namen. Tako za lastnike, ki opravljajo dela v gozdu, kot za izvajalce gozdarskih del velja, da v gozdu ne smejo puščati sledi goriv in maziv ter morajo opraviti vse potrebno, da se prepreči njihov izpust. Če se to vendarle zgodi, je tako onesnažena zemlja obravnavana kot »nevaren odpadek«. Da se prepreči nadaljnje onesnaženje, jo je treba iz gozda čim prej ustrezno odstraniti in deponirati na določen prostor, ki je namenjen nevarnim odpadkom. Če tega ne more storiti izvajalec sam, mora obvestiti ustrezne službe. Obvezna oprema vsakega stroja pri delu v gozdu za primer morebitnega izlitja olj so rokavice za enkratno uporabo, plastična vreča za odpadke in pivniki za olje. Pomembna je uporaba biološko razgradljivih maziv. Delo v gozdu z mehanizacijo in opremo, ki ni pravilno vzdrževana in vidno pušča gorivo in mazivo ter nima ustrezne opreme za primer izlitja olj, je prepovedano. 
a. Zahteve standarda FSC:

Moj Gozdar

- Upravljavci strojev so opravili ustrezno izobraževanje in se zavedajo zahtev v zvezi z zaščito vodnih virov.

- Rezervoarji z gorivom in skladišča so locirani tako, da razlitja zaradi poškodb, napak ali pretakanja goriva ne dosežejo vodnih virov.

- Vzpostavljen je sistem odvoza odpadkov na za to ustrezna mesta.

- Odpadki se ne odlagajo v vodotoke ali jezera, prav tako se jih ne zakopava.

- Odpadkov ni dovoljeno puščati v gozdu.

- Mehanizacija oz. delovišča so opremljena s pivniki za primere razlitij goriv, mazil, čistil.

b. Zahteve standarda PEFC:

- Prepovedana je uporaba kemičnih sredstev tudi recimo detergentov za pranje motorja in drugih delov stroja.

- Z gorivi, mazivi in drugimi sredstvi, s katerimi lahko onesnažimo gozdno zemljišče, moramo skrbno ravnati, da ne pride do njihovega vnosa v gozdno zemljišče. Iz gozda je treba odstraniti tudi ves odpadni material, ki je nastal zaradi vzdrževanja strojev.

\section{Evalvacija indikatorja (točkovanje): Ustrezno (4 točke):}

Organizacije izpolnjuje naslednje zahteve:

- Certifikat FSC ali PEFC ali

- ISO 14001 ali

- Poslovnik kakovosti, ki ureja področje ravnanja z odpadki (Poslovnik kakovosti je krovni dokument sistema kakovosti, v katerem izvajalec opredeli sistem in politiko za zagotavljanje kakovosti - opiše mehanizme in ukrepe, namenjene zagotavljanju kakovosti, in posledično zagotovi temelj, da se kakovost vzpostavi kot jedro delovanja IN potrdilo o zunanji presoji - zadostuje potrdilo zunanjega presojevalca (npr. presojevalske hiše Bureau Veritas)

\section{Delno ustrezno (2 točki):}

- Poslovnik kakovosti

\section{Dokazila:}

Za pridobitev vseh točk podjetje predloži:

- bodisi identifikacijski številki za certifikat FSC ali PEFC ali ISO 14001, na podlagi katerih se bo preverjala njihova veljavnost

- bodisi poslovnik kakovosti, ki vključuje področje urejenosti ravnanja z odpadki, IN skenirano potrdilo o zunanji presoji 


\subsection{Skladnost z okoljskimi omejitvami in zahtevami}

To področje v Sloveniji urejajo Zakon o varstvu okolja; Pravilnik o varstvu gozdov; Pravilnik o izvajanju sečnje, ravnanju s sečnimi ostanki, spravilu in zlaganju gozdnih lesnih sortimentov; in Uredba o tehničnih zahtevah za okoljsko primerno zasnovo proizvodov, povezanih z energijo.

Zakon o varstvu okolja določa, da je poseg v okolje dopusten le, če ne povzroča čezmerne obremenitve. Pomembno je, da vsa orodja, stroji in nevarne kemikalije, ki se uporabljajo v gozdarstvu, ustrezajo varnostnim in zdravstvenim zahtevam, kot to zahtevajo mednarodni in nacionalni standardi in priporočila; da se uporabljajo le za delo, za katero so bili zasnovani in izdelani, razen če niso bili predlagani za dodatno uporabo s strani pooblaščene osebe, ki je ugotovila, da je takšna uporaba varna. Z njimi lahko ravnajo le delavci, ki so za tako delo usposobljeni in/ali imajo potrebne certifikate. Pri gospodarjenju z gozdovi naj bi se negativni vplivi na okolje odpravili oz. zmanjšali, zagotavljalo naj bi se ohranjanje biotskega ravnovesja in obenem ekonomsko učinkoviti načini gospodarjenja z naravnimi viri.

\section{Zavzemati se je treba za:}

- zmanjševanje oz. odpravljanje motenj tal (površina tal, korenine, zbijanje tal, plasti inverzije, erozija ...), ki običajno nastanejo pri gospodarjenju z naravnimi viri,

- $\quad$ v primeru redčenj v največji možni reducirati poškodbe na preostalih drevesih v sestoju,

- zmanjševanje oz. odpravljanje škode na vodotokih,

- izboljševanje učinkovitost oz. produktivnost gospodarjenja z naravnimi viri,

- ter zagotavljati varnost ljudi, ki so neposredno vpleteni v procese gospodarjenje z naravnimi viri, in sicer z zagotavljanjem usposobljenih operaterjev pri sečnji in spravilu.

Dela naj se izvajajo tako, da se:

- pridobivanje lesa v čim večji meri opravi zunaj vegetacijske dobe;

- gozdnogojitvena dela opravljajo tako, da se v čim manjši meri vznemirjajo prostoživeče živali;

- gozdne prometnice ne gradijo prek nahajališč ogroženih rastlinskih vrst, mokrišč, mirnih con in zatočišč, razen v izjemnih primerih;

- tehnologija izbere in gozdna mehanizacija uporablja tako, da se gozdni ekosistem čim manj ogroža;

- uporabljajo biološko razgradljiva maziva v odprtih mazalnih sistemih verižnih žag za posek in izdelavo dreves na območjih s prvo stopnjo poudarjenosti hidrološke funkcije;

- uporabljajo stroji oziroma naprave, razen odprtih mazalnih sistemov verižnih žag, ki ne puščajo sledi olj in drugih maziv in imajo ustrezno opremo za preprečitev oziroma sanacijo morebitnega razlitja olj. 


\section{Moj Gozdar}

\section{Onesnaževanje}

Povzročitelj onesnaževanja mora izvesti ukrepe, potrebne za preprečevanje in zmanjšanje onesnaževanja, tako, da njegove emisije v okolje ne presegajo

predpisanih mejnih vrednosti.

Biotsko ravnovesje v gozdnem prostoru se vzpostavlja in vzdržuje z:

- ohranjanjem in vzpostavljanjem naravne sestave drevesnih vrst;

- ohranjanjem in vzpostavljanjem uravnoteženega razmerja med razvojnimi fazami gozdov in uravnotežene debelinske strukture gozda;

- ukrepi za varstvo gozdov pred škodljivimi abiotskimi in biotskimi dejavniki;

- načrtnim puščanjem odmrlega lesa;

- območji, pomembnimi za ohranitev prostoživečih živali oziroma rastlin;

- izvajanjem del za vzdrževanje in izboljšanje življenjskega okolja prostoživečih živali;

- zagotavljanjem usklajenih razmerij med gozdom in divjadjo;

- opravljanjem del v gozdu v času na način in s pripomočki, ki najmanj ogrožajo gozdni ekosistem.

\section{EMAS - Shema skupnosti za sisteme ravnanja z okoljem in njihovo presojo}

Sistem EMAS je namenjen podjetjem in drugim organizacijam, da ocenijo in izboljšajo svojo okoljsko učinkovitost ter obenem okrepijo konkurenčnost. Temelji na učinkovitosti, verodostojnosti in preglednosti. V Sloveniji je pristojni organ Ministrstvo za okolje in prostor, v imenu katerega izdaja odločbe o registraciji Agencija Republike Slovenije za okolje. Vključevanje v sistem EMAS omogoča agencija gospodarskim družbam, samostojnim podjetnikom posameznikom, zavodom in drugim organizacijam ali njihovim delom.

Organizacije, ki se registrirajo v sistem EMAS, morajo izpolnjevati naslednje zahteve:

- dokazati morajo skladnost z okoljsko zakonodajo,

- zavezati se morajo k nenehnemu izboljševanju svoje okoljske uspešnosti,

- dokazati morajo, da vodijo odprt dialog z vsemi zainteresiranimi stranmi,

- zaposlene morajo vključevati v izboljšanje okoljske uspešnosti organizacije,

- objaviti in posodabljati morajo potrjeno okoljsko izjavo EMAS za zunanje komuniciranje,

- opraviti morajo okoljski pregled (vključno z opredelitvijo vseh neposrednih in posrednih okoljskih vidikov), in

- $\quad$ se po uspešni preveritvi organizacije registrirati pri pristojnem organu (ARSO).

Organizacije lahko po registraciji začnejo uporabljati logotip. 


\section{Moj Gozdar}

Če ima podjetje že certifikat ISO 14001, to pomeni, da so bili že sprejeti nekateri najpomembnejši ukrepi za registracijo sistema EMAS, treba pa je izpolniti še dodatne zahteve (Evropski ..., 2011).

Več na: https://www.arso.gov.si/o\%20agenciji/okoljski\%20znaki/EMAS/

\section{Evalvacija indikatorja (točkovanje): Ustrezno (3 točke):}

- Podjetje je registrirano v shemo EMAS.

- Podjetje ima certifikat FSC/PEFC (opis glej 9.10) IN TUDI certifikat ISO 14001 (glej 9.15).

\section{Dokazovanje:}

- Številka registracije pri ARSO za EMAS.

- Za pridobitev točk podjetje posreduje dvoje: identifikacijsko številko za certifikat FSC ali PEFC, na podlagi katere se bo preverjala veljavnost, ter tudi certifikat skladnosti za ISO 14001-skeniran dokument.

\subsection{Ravnanje s fitofarmacevtskimi sredstvi}

Uporabo fitofarmacevtskih sredstev ( $v$ nadaljevanju FFS), kot so pesticidi oz. insekticidi, fungicidi, herbicidi, v gozdovih opredeljuje 31. člen Zakona o gozdovih ter Pravilnik o varstvu gozdov v 30. do 33. členu. Podrobneje način uporabe FFS v gozdovih določa Zakon o fitofarmacevtskih sredstvih.

Uporaba kemičnih sredstev v gozdu je prepovedana. Zavod za gozdove Slovenije (v nadaljnjem besedilu ZGS) lahko izjemoma, če za to ni alternativnih gozdnogojitvenih ali drugih bioloških ukrepov, izda dovoljenje za uporabo fitofarmacevtskih sredstev, ki so registrirana v skladu s predpisi, ki urejajo fitofarmacevtska sredstva, v primerih:

- izkoreninjenja tujerodnih škodljivih organizmov;

- zatiranja prenamnoženih škodljivih organizmov;

- zaščite gozdnega mladja pred divjadjo.

Fitofarmacevtska sredstva $v$ gozdu je dovoljeno uporabljati le $v$ koncentracijah ter s pripravami in na način, kot jih predpiše proizvajalec. ZGS določi zahteve za preprečitev tveganja, kot so poseben način aplikacije, označevanje mesta uporabe, preprečitev fizičnega dostopa in druge. Nanašajo se lahko samo na ciljno površino. Gozdni lesni sortimenti in kontrolni ali lovni kupi, na katerih je bilo uporabljeno fitofarmacevtsko sredstvo, se morajo označiti z opozorilnim znakom. Ta znak mora biti nameščen do izteka karenčne dobe kemičnega sredstva. Obliko znaka in njegovo namestitev določi ZGS. 


\section{Moj Gozdar}

Osnovno načelo pravilne uporabe fitofarmacevtskih sredstev je, da vedno uporabljamo le v Sloveniji registrirana sredstva, in to zgolj za namene in na način, za katere je uporaba dovoljena. $V$ primeru, ko $v$ Republiki Sloveniji ni registriranih ustreznih fitofarmacevtskih sredstev, ZGS pa ima na voljo podatke o njihovi uporabi in biološki učinkovitosti iz drugih držav, lahko predlaga organu, pristojnemu za registracijo fitofarmacevtskih sredstev, izdajo izjemnega dovoljenja ali dovoljenja za razširitev uporabe registriranega sredstva $\vee$ skladu $s$ predpisi, ki urejajo fitofarmacevtska sredstva. Uporaba pesticidov in drugih kemičnih sredstev v gozdu se omeji na neizogiben minimum, upoštevajoč primerne alternativne gozdnogojitvene in druge biološke ukrepe.

O številu izdanih dovoljenj za uporabo fitofarmacevtskih sredstev ter vrsti in količini sredstev mora ZGS voditi evidenco in za posamezna gozdnogospodarska območja poročati v okviru letnih poročil o gozdovih.

Območja, kjer uporaba FFS ni dovoljena:

- območja ožjih vodozbirnih območij, v bližini vodnih virov po navodilih za posamezno FFS,

- območja s 1. stopnjo rekreacijske in turistične funkcije,

- $\quad$ v gozdovih s certifikatom FSC, če ne gre za uporabo v izrednih razmerah, o katerih je obveščen certifikacijski organ in je podal soglasje za uporabo;

- $\quad$ v bližini čebeljih panjev (po potrebi lahko določimo odstranitev cvetoče podrasti blizu kupov za tretiranje).

Če ZGS presodi, da je uporaba FFS na sporočenih lokacijah mogoča oz. smiselna z vidika učinkovitosti zatiranja podlubnikov, izda lastniku dovoljenje za uporabo sredstva in potrebno količino sredstva skupaj z navodili za uporabo. V dovoljenju za uporabo FFS se navede lastnik gozda oz. gozdnih lesnih sortimentov, ki se bodo tretirali, oseba, ki bo izvajala tretiranje, ter številka potrdila o opravljenem izpitu iz fitomedicine, vrsta in količina izdanega FFS, lokacija tretiranja, številka odločbe, na podlagi katere je izdano dovoljenje, in datum veljavnosti dovoljenja. ZGS nato stranki izroči potrebno vrsto in količino FFS za izvedbo del, navodila za uporabo FFS, predpisana s strani proizvajalca, ter potrebno količino opozorilnih znakov, ki jih mora uporabnik pritrditi na tretirano površino, tako da je obvestilo dobro vidno. Obvestilo mora biti plastificirano ali v prozorni PVC-ovojnici. Uporabnik potrdi prejem FFS $s$ podpisom Potrdila o prejemu materiala, s čimer tudi potrjuje, da je bil s strani odgovorne strokovne osebe seznanjen z nevarnostmi, omejitvami in pogoji, ki veljajo za delo z izdano nevarno snovjo - FFS.

Zakon o fitofarmacevtskih sredstvih določa, da je za ravnanje s FFS potrebno usposabljanje, in sicer za poklicne uporabnike, prodajalce FFS in svetovalce za FFS ter druge osebe, ki želijo pridobiti potrdilo o pridobitvi znanja iz fitomedicine. Na podlagi 


\section{Moj Gozdar}

opravljenega usposabljanja za ravnanje s FFS se pridobi potrdilo o pridobitvi znanja iz fitomedicine - izkaznico. Izkaznica se izvajalcem ukrepov varstva rastlin izda za obdobje petih let, prodajalcem FFS in svetovalcem za FFS pa za obdobje treh let. Nadaljnje usposabljanje obsega obnovitveni tečaj brez preverjanja znanja, ki imetniku izkaznice omogoča, da posodobi znanje, ki je nujno za njegovo delo, ter da osveži znanja, ki so zajeta v osnovnem usposabljanju.

Za nakup in uporabo FFS, ki so dovoljena za nepoklicno rabo, izkaznica ni potrebna.

Seznam pravnih oz. fizičnih oseb, ki so registrirane za opravljanje dejavnosti izobraževanja, je dostopen na naslednji povezavi:

http://www.uvhvvr.gov.si/fileadmin/uvhvvr.gov.si/pageuploads/Tabela Seznam po nudnikov 2018.docx

Nadzor nad upoštevanjem tega zakona in predpisov, izdanih na njegovi podlagi, opravljajo fitosanitarni inšpektorji oziroma inšpektorice.

\section{Evalvacija indikatorja (točkovanje): Ustrezno (2 točki):}

Organizacija ima vzpostavljeno primerno ravnanje s pesticidi / fitofarmacevtskimi sredstvi in redno usposablja ljudi za ravnanje s fitofarmacevtskimi sredstvi.

\section{Dokazovanje:}

Podjetje predloži skenirano veljavno potrdilo o pridobitvi znanja iz fitomedicine (izkaznico).

\subsection{Sodelovanje ali finančna podpora v lokalnih projektih}

Odgovornost podjetij se kaže v treh širokih področjih: družba, ekonomija in okolje. Podjetja svojo družbeno odgovornost in naravnanost udejanjajo skozi svojo družbeno odgovorno orientiranostjo in ravnanjem ali skozi projekte na različnih področjih (Kuntarič, 2016). Družbeno odgovorne iniciative so ene izmed pomembnejših aktivnosti, ki jih prištevamo k družbeni odgovornosti. Kotler in Lee (2005) omenjene iniciative definirata kot aktivnost podjetij, da podprejo in se zavzamejo za pomembne tematike v družbi in s tem izpolnjujejo svojo zavezo družbene odgovornosti. Podjetja lahko pomoč lokalni skupnosti izkažejo na različne načine, kot so: denarni prispevki, nepovratna sredstva, štipendije, omogočanje šolskih praks, socialno zaposlovanje, oglaševanje, publiciteta, promocijsko sponzorstvo, specifična znanja, donacije $v$ materialni obliki (izdelki), prostovoljstvo zaposlenih in dostop do distribucijskih kanalov, udeležba $v$ izobraževanju lokalne skupnosti, partnerstva z lokalnimi organizacijami.

Omenjena avtorja opredelita različne vrste družbenih iniciativ: 
- Promocije dobrodelnih namenov: organizacija prispeva denarna ali materialna sredstva z namenom povečanja zavedanja in reševanja določene družbene problematike.

- Marketing z namenom: organizacija se zaveže, da bo glede na prodajo prispevala del dobička za določeno družbeno problematiko (npr. od vsakega prodanega proizvoda).

- Socialni marketing: organizacija podpira projekte za spremembe na področju zdravja ljudi, varnosti, okolja in blaginje skupnosti nasploh.

- Filantropija podjetja: je neposreden prispevek podjetja določeni družbeni problematiki, lahko gre za direktne denarne donacije ali pa za prispevke v blagu.

- Prostovoljstvo v skupnosti: organizacija podpira in spodbuja svoje zaposlene in partnerje, da prispevajo svoj čas in znanje in tako podpirajo lokalne skupnosti.

- Družbeno odgovorne poslovne prakse: organizacija prostovoljno v svoje delovanje vgradi oz. uvede nove načine poslovanja, ki prispevajo k blaginji družbe in okolja.

\section{Evalvacija indikatorja (točkovanje):}

\section{Ustrezno (3 točke):}

Organizacija izkazuje pomoč lokalni skupnosti (denarni prispevki, nepovratna sredstva, oglaševanje, publiciteta, promocijsko sponzorstvo, specifična znanja, udeležba v izobraževanju lokalne skupnosti, štipendije, omogočanje šolskih praks, socialno zaposlovanje, donacije v materialni obliki (izdelki), prostovoljstvo zaposlenih in dostop do distribucijskih kanalov, organizacija daruje določen delež denarja od vsakega prodanega proizvoda).

\section{Dokazila:}

Organizacija mora dokazati, da sodeluje ali finančno podpira lokalno skupnost v eni izmed predstavljenih oblik. Tako organizacija priloži dokument, na katerem je razviden opis podpor $\vee$ zadnjem obdobju. $V$ dokumentu mora biti za posamezno aktivnost navedeno, komu je namenjena.

\subsection{0 Članstvo v interesnih združenjih}

Organizacija je $v$ interesnem združenju z namenom skupnega nastopa izbrane interesne skupine $v$ zakonodajnih postopkih ali si s članstvom zagotovi tehnično, pravno in ekonomsko svetovanje.

1. Kmetijsko gozdarska zbornica Slovenije (KGZS) 


\section{Moj Gozdar}

Kmetijsko gozdarska zbornica Slovenije je nevladna organizacija, ki predstavlja interese članstva v zakonodajnih postopkih, svojim članom zagotavlja brezplačno tehnično, pravno in ekonomsko svetovanje v kmetijstvu, gozdarstvu, jih obvešča o aktualnih dogodkih, promovira podeželje, kmetijstvo, gozdarstvo in ribištvo (udeležba na sejmih, organizacija okroglih miz, kongresov, dogodkov....) ter izobražuje svoje člane.

Izvajalci del v gozdovih morajo biti po Zakonu o Kmetijsko gozdarski zbornici Slovenije (ZKGZ) vključeni v Kmetijsko gozdarsko zbornico Slovenije, če izpolnjujejo spodaj navedene pogoje za obvezno članstvo.

Člani zbornice so fizične in pravne osebe, ki se ukvarjajo s kmetijstvom, gozdarstvom in ribištvom:

- Fizične osebe: lastniki, zakupniki, uživalci, imetniki pravice uporabe kmetijskih zemljišč in gozdov na območju Republike Slovenije, katerih katastrski dohodek za leto 2018 znaša najmanj 91,85 € (v skladu z vsakoletno valorizacijo katastrskega dohodka).

- Pravne osebe, ki imajo sedež v Republiki Sloveniji in so lastnice kmetijskih zemljišč oziroma gozdov na območju Republike Slovenije razen oseb javnega prava ali se ukvarjajo pretežno s kmetijsko, gozdarsko ali ribiško dejavnostjo, ne glede na pravno obliko.

Poleg obveznih ima zbornica tudi prostovoljne člane, ki so v članstvo lahko sprejeti na lastno zahtevo. To so fizične ali pravne osebe, ki opravljajo kmetijsko, gozdarsko ali ribiško dejavnost, a ne izpolnjujejo zakonsko določenih kriterijev za obvezno članstvo.

Na področju gozdarstva Kmetijsko gozdarska zbornica pospešuje razvoj, izboljšuje ekonomske razmere in zagotavlja storitve strokovnih služb, ki so v pomoč pri gospodarjenju z gozdom (Kmetijsko ..., 2019).

Več na: https://www.kgzs.si//

\section{Obrtno-podjetniška zbornica Slovenije}

Obrtno-podjetniška zbornica Slovenije je združenje, ki združuje vse pravne in fizične osebe, ki opravljajo obrtno in obrti podobno pridobitno dejavnost v republiki Sloveniji. Poslanstvo Obrtno-podjetniške zbornice je zastopanje interesov obrtnikov in podjetnikov pred državo, informiranje in opravljanje storitev za člane, povezovanje članov, izvajanje javnih pooblastil, skrb za promocijo obrti in omogočanje cenejše udeležbe na sejmih ter poslovnih srečanjih. Organizirajo številna izobraževanja in pripravljajo poslovne informacije, ki jih člani potrebujejo pri vsakodnevnem poslovanju. Članstvo je prostovoljno.

Več na: https://www.ozs.si/ 
3. Združenje lesne in pohištvene industrije

Združenje lesne in pohištvene industrije je največja prostovoljna asociacija slovenskih lesarskih in pohištvenih podjetij. Zastopa interese podjetij v odnosih z državo in sindikati pri oblikovanju razmer za delo in poslovanje ter pri zagotavljanju razmer za gospodarski razvoj. Združenje spremlja tekoča gospodarska gibanja v dejavnostih, oblikuje panožne usmeritve in stališča glede reševanja tekočih in razvojnih vprašanj ter podpira panožne akterje pri reševanju panožnih problemov. Članom zagotavlja nove priložnosti za izboljšanje konkurenčnosti.

Več na: https://www.gzs.si/zdruzenje lesne in pohistvene industrije

\section{Lesarski grozd}

Lesarski grozd povezuje zaposlene $v$ gozdarstvu in lesno predelovalni industriji ter lesarske raziskovalne ustanove. Skupni cilj vseh dejavnosti je izboljševanje konkurenčnosti članov grozda, razumevanje potreb članov in oblikovanje projektov za njihovo uresničitev. Od leta 2007 Lesarski grozd deluje povezano z Združenjem lesne in pohištvene industrije (ZLPI) pri GZS. ZLPI vodi panožno politiko in koordinacijo ter usklajuje interese članov s širšim okoljem, Lesarski grozd pa predstavlja operativno podporo uresničevanju panožnih ciljev.

Več na: http://www.lesarski-grozd.si//

\section{Zavod SLOLES, slovensko lesno združenje}

Združenje združuje podjetja z dejavnostjo proizvodnje žaganega lesa ter drugih lesnih proizvodov in nadaljnje obdelave žaganega lesa v polizdelke, ter podjetja, ki opravljajo dejavnost trgovine z žaganim lesom in lesnimi polizdelki. Cilji združenja so krepitev konkurenčne prednosti podjetij v sektorjih primarne in sekundarne predelave lesa $v$ gozdno-lesnih vrednostnih verigah, odprtje novih prodajnih poti v Sloveniji in tujini. Namen in dejavnost združenja je razvoj, povezovanje, kvalitetno delo vseh slovenskih žagarjev in trgovcev z lesom.

več na: https://www.sloles.eu/

6. Druga združenja s področja gozdarstva/lesarstva 


\section{Evalvacija indikatorja (točkovanje): Ustrezno (2 točki):}

Organizacija je član v vsaj enem izmed zgoraj opisanih združenj. Če podjetje predloži dokazilo o članstvu v katerem drugem združenju s področja gozdarstva/lesarstva (točka 7), ustreznost presodi neodvisni strokovni presojevalec.

\section{Dokazilo:}

Skenirano potrdilo o članstvu v katerem izmed zgoraj naštetih združenj ali v drugih združenjih.

\subsection{Sistem upravljanja s strankami}

Upravljanje odnosov s strankami je poslovna strategija, s katero skušamo zbrati čim več informacij o strankah, njihovih potrebah in vedenjskih navadah. S strankami želimo vzpostaviti dolgoročne in čim trdnejše odnose. Dober odnos s strankami je ključen za dober poslovni uspeh. Za podjetje je ključnega pomena, da vzpostavi kakovostne odnose s svojimi strankami, ki so v prihodnosti osnova za obojestransko koristno in dolgoročno poslovno sodelovanje.

Vsaka organizacija na določen način spremlja svoje stranke. Manjša podjetja imajo tako rekoč svoje redne stranke "v glavi", drugi imajo kontaktne številke svojih strank zapisane v zvezkih in beležnicah. Ob razvoju tehnologije je danes tovrstno beleženje in spremljanje strank redkost. Arhiv strank vsakega podjetja je v osnovi predstavljen v obliki elektronskih preglednic v različnih programskih orodjih.

Vsak od omenjenih pristopov spremljanja strank ima precej pomanjkljivosti. Spremljanje odnosov s strankami se v večini že podpira tudi s programskimi rešitvami. Eden izmed tovrstnih programov je CRM (Customer Relationship Management). CMRprogrami nam omogočajo zbiranje podatkov, izdelavo analiz posameznih strank ali skupin strank in posledično tudi možnost priprave individualnega pristopa $k$ strankam. Ponudnikov storitev CRM je vedno več, zaradi česar je izbira raznovrstna (Microsoft Dynamics, Intrix CRM, Panorama, SAP CRM, Abraxas CRM CatPro, Salesforce, Oracle CRM On Demand, Think!CRM, Nimble, Sugar CRM).

Med najpogostejše aktivnosti, ki sestavljajo CRM v organizacijah so:

- izdelana baza podatkov o obstoječih strankah,

- iskanje novih strank,

- spremljanje dobičkonosnosti posameznih strank,

- spremljanje zadovoljstva strank,

- merjenje kakovosti odnosov s strankami.

Certifikat ISO 9001 se nanaša na sistem vodenja kakovosti. Osnovan je na podlagi osmih načel, v katerih zasledimo poudarjanje pomena upravljanja odnosov s 
strankami oz. odjemalci. Organizacije so odvisne od odjemalcev, zato morajo razumeti njihove potrebe, izpolnjevati njihove zahteve, želje in pričakovanja. Standard opredeljuje, da mora organizacija uvesti postopke komuniciranja z odjemalci glede informacij o proizvodu, poizvedbah, pogodbah, od odjemalcev pa mora pridobivati tudi povratne informacije (Hočevar, 2016).

\section{Evalvacija indikatorja (točkovanje):} Ustrezno (3 točke):

Organizacija je sposobna dokazati, da

- $\quad$ ima pridobljen certifikat ISO 9001.

ALI

- ima izdelan arhiv obstoječih strank v fizični ali elektronski obliki in uporablja eno izmed programskih oprem, namenjeno upravljanju odnosov s strankami (Microsoft Dynamics, Intrix CRM, Panorama, SAP CRM, Abraxas CRM CatPro, Salesforce, Oracle CRM On Demand, Think!CRM, Nimble, Sugar CRM, drugo).Enkrat na letni ravni ali ob mejnikih (npr. 1 leto sodelovanja) obdaruje zveste stranke (koledar, majica, kapa itd.) ali pa organizira pogostitev zvestih strank.

\section{Delno ustrezno (1,5 točke):}

Organizaciji, ki nima certifikata ISO 9001 in pri drugem kriteriju izpolnjuje le eno izmed navedenih zahtev, se prizna polovično število točk.

\section{Dokazovanje:}

Podjetje, ki ima pridobljen certifikat ISO 9001, priloži skeniran certifikat.

- Podjetje, ki ima izdelan arhiv obstoječih strank v fizični ali elektronski obliki:

- priloži dokument, s katerim potrjuje, da ima izdelan imenik obstoječih strank.

- Kot ustrezen dokument se upošteva krajši izsek iz baze strank. Lahko je priložen v obliki elektronske preglednice (Excel) ali kot skeniran imenik strank v primeru, če ima organizacija bazo strank v fizični obliki.

- Uporablja eno izmed programskih oprem, namenjeno upravljanju odnosov s strankami (organizacija priloži licenco ali račun, s katerim potrjuje nakup obravnavane programske opreme).

- Organizacija priloži fotografijo darilnih rekvizitov (majice, kape, koledarji) ali fotografijo organiziranega dogodka. Zahtevam ustreza tudi račun, s katerega je razvidno, da gre za nakup darilnih rekvizitov, namenjenih promociji organizacije. 


\subsection{Register pohval in pritožb}

Slovar slovenskega knjižnega jezika pritožbo definira kot izjavo, s katero se izraža nezadovoljstvo zaradi neprimernosti oziroma neustreznosti nečesa. Pritožbe strank oziroma poslovnih partnerjev niso nobena redkost. Pritožbe $v$ večini primerov nastajajo zaradi dveh razlogov. Najpogostejše je nezadovoljstvo nad izdelkom ali storitvijo ali pa zaradi nezadovoljstva nad vedenjem zaposlenih.

Horvat (2005) navaja, da se stranke težko odločijo, da bi se podjetju ob zaznanih problemih tudi dejansko pritožile. Zato je bistvenega pomena, da se podjetje zaveda dragocenosti vsake pritožbe, saj je ta dobrodošla informacija, ki lahko prispeva $k$ boljšemu poslovanju podjetja na dolgi rok. Zato je priporočljivo, da zaposlenim politika podjetja narekuje, da obdržijo do pritožb strank pozitiven pristop:

- na stranko, ki se je pritožila, morajo zaposleni gledati kot na osebo, ki si je bila pripravljena vzeti čas in nameniti energijo temu, da bi jih seznanila s problemi, ki se pojavljajo v podjetju,

- pritožbe predstavljajo možnosti za naložbe v odpravo virov nezadovoljstva, saj odkrivajo nastale probleme in tako delujejo kot neke vrste opozorilni sistem,

- pritožbe so priložnost za ohranitev strank, saj stranka s svojo pritožbo podjetju nekako daje priložnost, da odpravi napako ter tako z njo ponovno vzpostavi pozitiven odnos,

- pritožba je izziv za podjetje, saj se z uporabo strokovnega znanja, kreativnega mišljenja in spretnosti pri odnosih z ljudmi kakovost ponujenih storitev in izdelkov v prihodnje še poveča.

Pritožbe se zelo pogosto razume kot negativno kritiko, v resnici pa so pritožbe odličen vir informacij za izboljšanje naših izdelkov in storitev. Pritožbe tako predstavljajo pomemben način spremljanja kakovosti storitev v podjetju. Zavedati se moramo, da brez stalnega spremljanja kakovosti storitev organizacija dolgoročno ne more zadovoljevati svojih strank. Potreba po sistemu ravnanja s pritožbami izhaja iz dejstva, da se nezadovoljna stranka praviloma obrne h konkurenci. Poleg tega svojo negativno izkušnjo širi v svojem okolju, kar posledično lahko vpliva na finančni položaj podjetja. $\checkmark$ organizacijah pogosto rešujejo samo posledice težav in ne storijo ničesar, da bi poiskali dejanske vzroke težav in jih tudi odpravili oziroma zmanjšali na čim nižjo raven. Informacije, zbrane $v$ zvezi s pritožbami, in same pritožbe je treba ustrezno analizirati, ovrednotiti in sprejeti določene zaključke, ki bodo omogočile odpravo oziroma zmanjševanje negativnih učinkov nezadovoljstva.

Za uspešno delovanje neke organizacije standard ISO 9001 poudarja izpolnjevanje zahtev in večanje zadovoljstva odjemalcev. Glede na sedanje razmere na trgu kakovosten proizvod še ni zadosten pogoj za uspešno poslovanje, ker ni nujno, da odseva tudi zahteve in pričakovanja naročnika. Kupec je edini končni razsodnik o kakovosti proizvoda. Za zagotavljanje nenehnega izboljševanja je treba prek pritožb 
in mnenj ohraniti pozornost do odjemalcev. Pritožba in reklamacija sta najboljša informacija o tem, kaj je z nekim izdelkom oz. storitvijo narobe. Cilj je torej identifikacija problema, odpravljanje problema, zadovoljstvo odjemalca in izboljšanje izdelkov in storitev, ki jih podjetje ponuja (Hočevar, 2016).

V zasebnih podjetjih register pritožb in pohval ni zakonsko predpisan (Žnidaršič, 2015). vsako podjetje se torej v skladu s svojo poslovno politiko odloči, kako bo obravnavalo problematiko pritožb. Da organizacija sledi predstavljenemu indikatorju, mora imeti vzpostavljen register pritožb, ki je namenjen strankam in poslovnim partnerjem. Posamezne pritožbe mora obravnavati ter na podlagi utemeljenih pritožb sprejeti ukrepe. V primeru, da ima organizacija vzpostavljen program upravljanja s strankami (CRM), sta poleg baze strank, aktivnosti spremljanja zadovoljstva strank in merjenja kakovosti odnosov s strankami že vključeni $v$ samo programsko opremo in zadostujeta zahtevanemu kriteriju.

\section{Evalvacija indikatorja (točkovanje):}

\section{Ustrezno (2 točki):}

Organizacija pri predstavljenem indikatorju pridobi vse točke, če izpolnjuje enega od treh kriterijev:

- Organizacija ima pridobljen certifikat ISO 9001.

- Organizacija ima vzpostavljen register pritožb in pohval, iz katerega je razvidna tudi analiza pritožbe in sprejeti novi ukrepi, ali pa ima vzpostavljen CRM-portal, prek katerega spremlja svoje odnose s strankami.

- Organizacija ima na spletnem portalu MojGozdar na letni ravni pridobljenih minimalno deset ocen uporabnikov oz. strank.

\section{Dokazila:}

- Organizacija mora kot dokazilo priložiti skeniran certifikat ISO 9001.

- V primeru izpolnjevanja drugega kriterija mora priložiti del izseka registra pritožb in pohval in poročati o opravljeni analizi pritožb in sprejetih ukrepih (npr. stimulacija/destimulacija delavca). V primeru, da ima vzpostavljen CRMportal, priloži licenco ali račun, s katerim potrjuje nakup obravnavane programske opreme.

- Zadostno število pridobljenih ocen uporabnikov spletnega portala MojGozdar bo preveril neodvisni strokovni presojevalec. 


\subsection{Glavna dejavnost po SKD}

Moj Gozdar

Standardna klasifikacijska dejavnosti (v nadaljevanju besedila SKD) se uporablja za določanje dejavnosti poslovnih subjektov, njihovo razvrščanje z vidika njihove dejavnosti $v$ različne uradne in druge administrativne podatkovne zbirke ter za potrebe statistike in analitike $v$ državi in na mednarodni ravni.

Glavno merilo pri strokovni oceni indikatorja »Glavna dejavnost po SKD« bo presoja, ali ima družba registrirano eno ali več dejavnosti, ki so skladne s področjem in cilji gozdno- lesnih verig.

V Prilogi 1 so iz trenutno veljavnega kataloga Standardna klasifikacija dejavnosti (2008) izbrane vse dejavnosti, ki se bodo pri strokovni oceni obravnavanega indikatorja upoštevale kot ustrezne ali delno ustrezne. Posamezna dejavnost je v preglednici predstavljena s šifro kategorije, deskriptorjem ter opisom ustrezne skladnosti s področjem in cilji gozdno-lesnih verig.

\section{Evalvacija indikatorja (točkovanje):}

Ustrezno (2 točki):

- glavna dejavnost organizacije je skladna s področjem gozdno-lesnih verig, navedenih v prilogi 1 .

\section{Delno ustrezno (1 točka):}

- glavna dejavnost je delno skladna s področjem gozdno-lesnih verig, navedenih v prilogi 1 .

\section{Dokazila:}

Organizacija priloži dokument, s katerim dokazuje skladnost registriranih dejavnosti s predvidenimi.

\subsection{Javnost podatkov}

Družbena odgovornost predstavlja dolgoročni uspeh podjetja in je smiselni cilj v kriznem obdobju. Omogoča izboljšanje delovne klime in motivacijo zaposlenih, krepi poslovno strategijo, predstavlja konkurenčno prednost, gradi na povezanosti med deležniki, predstavlja določeno stopnjo varnosti za investitorje in hkrati sili podjetja k transparentnosti.

Poslovanje demokratičnega podjetja je popolnoma odprto in transparentno. Zaposleni $v$ podjetju so ves čas seznanjeni s finančnimi rezultati, strategijo in poslovnimi načrti. Demokratično podjetje svojega organizacijskega znanja namreč ne skriva pred svojimi zaposlenimi, temveč neprestano spodbuja njegovo širjenje prek internih informacijskih sistemov in drugih komunikacijskih orodij. Odprtost poslovanja se izkazuje na vseh nivojih, od transparentne arhitekturne ureditve poslovnih prostorov do javnosti podatkov o tekočem finančnem poslovanju podjetja. 


\section{Moj Gozdar}

Razlog za tako odprto politiko poslovanja je v prepričanju, da bodo zaposleni ob boljši informiranosti manj časa porabili za špekulacije in ugibanja o stabilnosti podjetja, poleg tega pa bodo sposobni sprejemati bolj natančne in odgovorne odločitve. Odprtost, iskrenost, poštenje ter zaupanje so osnova za uspešno poslovanje demokratičnega podjetja. Odnosi med zaposlenimi so neformalni, temeljijo na družinskih vrednotah in medsebojnem spoštovanju. S tem se demokratično podjetje izogne vsem oblikam tiranije ter zaposlenim omogoča, da na delo prihajajo sproščeno in z veseljem (Pompe 2009).

\section{Evalvacija indikatorja (točkovanje): Ustrezno (2 točki):}

- Organizacija vsaj $1 x$ letno v sistemu MojGozdar poroča o cenah gozdarskih storitev.

- Organizacija vsaj $1 x$ letno v sistemu MojGozdar poroča o obsegu proizvodnje za vse zastopane gozdarske storitve.

- Organizacija v sistemu MojGozdar poroča in redno vzdržuje seznam mehanizacije, ki jo uporablja pri opravljanju gozdarskih storitev.

\section{Dokazovanje:}

Organizacija poskrbi, da so na dan presoje ažurirani vsi podatki v spletnem informacijskem sistemu MojGozdar, ali pa priloži podatke, da jih v sistem vnese skrbnik sistema.

\subsection{Dolgoročne in trajne pogodbe}

Strategija zniževanja stroškov, osredotočanje na ključne prednosti podjetja in boljše obvladovanje operativnih stroškov so najpomembnejši razlogi za prenos dejavnosti k zunanjim izvajalcem. Ročnost pogodb in trajanje sodelovanja sta pomembna kazalca pristopa k umeščanju v časovne (dolgoročno in kratkoročno) in vsebinske razsežnosti sodelovanja obeh udeležencev $v$ razmerju zunanjega izvajanja dejavnosti. Kratkoročne pogodbe $z$ ročnostjo do enega leta in zastopanostjo s 36 odstotki v zunanjem izvajanju ne dosegajo razvojne, kaj šele temeljne politike podjetja; značilne so za tekoče poslovanje in tekočo politiko (Kavčič 2009).

Dolgoročnejše strateško snovanje, izvajanje in usmerjanje razmerij zunanjega izvajanja je lahko tako za dajalce kot za izvajalce bolj koristno in manj tvegano od kratkoročnega in enostranskega. Kavčič (2009) z raziskavo ugotavlja, da je lahko zunanje opravljanje dejavnosti tudi v slovenskih razmerah učinkovito sredstvo za povečevanje kratkoročne, zlasti finančne uspešnosti podjetja. Širšo verifikacijo pričakovanih koristi za podjetja, ki se odločajo za prenos dejavnosti, potrjujejo tudi številne raziskave, opravljene v Nemčiji in drugih zahodnoevropskih državah. 
V razmerjih zunanjega izvajanja dejavnosti mnogokrat prevladujejo kratkoročni interesi dajalca (zmanjševanje stroškov, prenos ugašajočih ali okoljsko oporečnih dejavnosti, pridobivanje zmogljivosti za kratkoročno obdobje ipd.). Dajalci kot prejemnike pogosto izbirajo takšna podjetja, ki jim grozi latentna ali potencialna kriza in nimajo druge izbire niti za kratkoročno preživetje. V okolju, ki se gospodarsko hitro razvija, lahko prednosti prejemnika zunanjega izvajanja dejavnosti (npr. stroški) hitro ugašajo, dajalec izločene dejavnosti pa išče drugega prejemnika, npr. v gospodarsko manj razviti deželi; takšna prehodna in strateško malo premišljena razmerja zunanjega izvajanja imajo lahko neugodne posledice (Kavčič 2009).

\section{Evalvacija indikatorja (točkovanje): Ustrezno (3 točke):}

- Organizacija je sposobna dokazati usmerjenost k dolgoročnejšemu strateškemu snovanju, izvajanju in usmerjanju. Dolgoročna usmerjenost pomeni, da ima organizacija z zunanjimi partnerji podpisan sporazum ali pogodbo o sodelovanju za obdobje več kot enega leta.

\section{Dokazovanje:}

Preslikan dokument (prva in zadnja stran) s katerega je razvidna zaveza z zunanjimi partnerji o dolgoročnemu sodelovanju (npr. SIDG, sečnja v občinskih gozdovih, pogodba o sodelovanju z večjimi lastniki gozdov). Organizacija lahko predloži kakršenkoli dokument, ki dokazuje dolgoročno sodelovanje, na podlagi katerega se bo presojevalec odločil, ali ustreza navedenemu indikatorju.

\subsection{Pokrivanje več vmesnih procesov (lastna primarna predelava itd.)}

Za Slovenijo sta gozd in les strateška prednost, saj sta tol naravna vira, s katerima je Slovenija bogata. Resolucija o nacionalnem gozdnem programu (št. 111/07) les opredeljuje kot pomemben obnovljiv vir, ki že od nekdaj prispeva k razvoju industrije in vsega gospodarstva v Republiki Sloveniji, še posebej na podeželju. Kot pomemben korak k nadaljnjemu razvoju se poudarja predelava lesa, ki pripeva k dodani vrednosti v domačem okolju. Ministrstvo za kmetijstvo, gozdarstvo in prehrano je leta 2012 sprejelo Akcijski načrt za povečanje konkurenčnosti gozdno-lesne verige do leta 2020. Načrt poudarja pomembnost doseganja dodane vrednosti vsakemu členu gozdnolesne predelovalne verige, vključno s celulozno, papirniško in kemično industrijo ter uporabo lesne biomase v energetske namene novih tehnologij.

Ključni cilji akcijskega načrta so:

- povečanje poseka in negovanosti gozdov, skladno z načrti za gospodarjenje z gozdovi, 


\section{Moj Gozdar}

- povečanje količine in predelave lesa na višjih zahtevnostnih stopnjah z novimi tehnologijami,

- ustvarjanje trga za lesne proizvode in storitve,

- nova delovna mesta in rast dodane vrednosti na zaposlenega $v$ lesnopredelovalni panogi.

Gozdno-lesna veriga $\vee$ Sloveniji sega od trajnostnega, multifunkcionalnega in sonaravnega gospodarjenja z gozdovi, prek predelave lesa, oblikovanja, proizvodnje in prodaje lesnih izdelkov, do izrabe lesnih ostankov za proizvodnjo energije. Gozdarstvo je kot gospodarska panoga sestavljeno iz več členov v sami gozdno-lesni verigi. Gozdarske člene gozdno-lesne verige tvori niz proizvodnih procesov, s katerimi naravne vire iz gozdov pretvarjamo v proizvode in storitve. Sam proces pridobivanja lesa in nege gozdov se v veliki meri razvija po uveljavljenih proizvodnih fazah:

- sečnja z motorno žago,

- spravilo lesa s traktorji,

- gojenje,

- strojna sečnja,

- žičniško spravilo lesa,

- prevozlesa.

Sledi primarna predelava lesa, kjer nastajajo številni polproizvodi z višjo dodano vrednostjo, posledično pa zagotavljajo številne zaposlitve in krepijo zavest o potencialih lesne surovine $\vee$ gozdu. Pod izdelke primarne predelave lesa štejemo energente (sekanci, peleti, drva), ki so tudi končni izdelki in primerni za direktno prodajo na trgu. $V$ drugi vrsti pa pod izdelke primarne predelave, primerne za nadaljnjo predelavo, štejemo žagan les, furnir, celulozo in druge pomožne materiale.

Zmanjševanje števila vmesnih procesov vzdolž proizvodne verige potrošniku omogoča, da se bolj približa proizvajalcu, kar prispeva k boljšemu plačilu proizvajalcu za proizvod, k pravičnejši delitvi vrednosti med deležniki ter omogoča potrošnikom, da zlahka prepoznajo poreklo surovin.

\section{Evalvacija indikatorja (točkovanje):}

\section{Ustrezno (3 točke):}

Organizacija, ki izpolnjuje oba pogoja, pridobi vse točke:

- Organizacija opravlja vsaj 3 zaporedne dejavnosti ali storitve pri procesu pridobivanja lesa.

- Organizacija opravlja dejavnost iz primarne predelave lesa ali nadaljnje proizvodnje.

\section{Delno ustrezno (1,5 točke):}

- Organizacija, ki izpolnjuje le enega izmed navedenih pogojev, delno ustreza zahtevam izbranega indikatorja in s tem pridobi polovico točk. 


\section{Dokazovanje:}

Preverjanje na podlagi seznama ponudnikov v gozdovih, ki ustrezajo inšpekcijskemu pregledu in drugim predpisanim pogojem. Organizacija, ki izvaja primarno predelavo ali proizvodnjo izdelkov iz lesa, priloži dokument, s katerim dokazuje, da ima po standardni klasifikacijski dejavnosti to tudi registrirano.

\subsection{Naložbe v osnovna sredstva}

Osnovna sredstva so proizvedena sredstva, ki se uporabljajo v proizvodnem procesu več kot eno leto, in sicer ponavljajoče oz. nepretrgoma (Ilič, 2019). Gre torej za stvari, ki se uporabljajo pri izdelovanju izdelkov ali opravljanju storitev, ki so dejavnost podjetja. Ta sredstva lahko podjetje kupi, naredi ali najame, lahko jih pa pridobi tudi na druge načine (npr. ob prevzemu drugega podjetja, z dokapitalizacijo s stvarnim vložkom itd.). Nabavna vrednost osnovnega sredstva, skupaj s stroški, ki so potrebni, da se osnovno sredstvo usposobi za uporabo - predstavlja začetno vrednost osnovnega sredstva. Z uporabo in sčasoma praviloma osnovno sredstvo izgublja svojo vrednost, saj se izrablja in tudi zastareva. So pa tudi izjeme. Tako se npr. stavbno zemljišče ne izrablja, zaradi lokacije in povpraševanja pa mu tudi sicer lahko vrednost narašča. Med drugo opremo so lahko tudi umetniška dela, ki jim prav tako čas le povečuje vrednost (Peršak, 2019).

V skladu z ESA 2010 in slovenskimi računovodskimi standardi se osnovna sredstva delijo $v$ dve skupini:

- opredmetena osnovna sredstva (gradbeni objekti in prostori, stroji in oprema, prevozna sredstva ter biološka sredstva), in

- neopredmetena sredstva (računalniška programska oprema in podatkovne baze, razvedrilni, literarni in drugi umetniški izvirniki, študije, projekti).

Osnovni pomen naložb v osnovna sredstva je vzpostavljanje opredmetenih osnovnih sredstev z namenom razširiti poslovanje ali nadomestiti stara osnovna sredstva zaradi vzdrževanja poslovanja ali zmanjševanja stroškov, povečanja proizvajanja obstoječih proizvodov ali opravljanja obstoječih storitev, proizvajanja novih proizvodov ali opravljanja novih storitev, varstva okolja in varnosti itd (Turk, 2019).

\section{Evalvacija indikatorja (točkovanje): Ustrezno (4 točke):}

Organizacija v preteklih treh letih dosega pozitivno stopnjo rasti investicij v osnovna sredstva. Organizacija, katere investicije presegajo amortizacijsko vrednost, izpolnjuje zahteve indikatorja. 


\section{Dokazovanje:}

Doseganje indikatorja se izračuna na podlagi podatka o "Opredmetenih osnovnih sredstvih", ki so za večino pravnih subjektov objavljene v bilanci stanja v "Javnih objavah letnih poročil" in so javno dostopne na spletnem pregledovalniku AJPES-a.

Triletna stopnja rasti se izračuna po enačbi:

\subsection{Bruto dodana vrednost na zaposlenega}

Kazalnik dodane vrednosti na zaposlenega izkazuje, kolikšna je povprečna novo ustvarjena vrednost na zaposlenega. Večja vrednost kazalnika družbe ob izkazovanju čistega dobička pomeni večjo kakovost poslovnih učinkov (proizvodov in storitev) ter tako uspešnejšo gospodarsko družbo (AJPES).

Čeprav so velika podjetja (z več kot 250 zaposlenimi oziroma z letnim prometom, ki presega 50 milijonov evrov) praviloma tista, ki ustvarjajo največjo dodano vrednost na zaposlenega, pa v absolutnem znesku največ v novi vrednosti, ki se ustvari v gospodarstvu, prispevajo mikro, majhna in srednje velika podjetja (Dodana ..., 2015).

Družbe so po podatkih iz izkaza poslovnega izida za leto 2018 ustvarile 22.355.427 tisoč evrov neto dodane vrednosti, $9 \%$ več kot v letu 2017. Neto dodana vrednost na zaposlenega je znašala 44.415 evrov ali $2 \%$ več kot v letu 2017. Neto dodana vrednost je na področju Kmetijstvo in lov, gozdarstvo, ribištvo leta 2018 znašala 128.578.000 EUR (AJPES).

IZRAČUN:

Povprečna bruto dodana vrednost na zaposlenega (BDV/Z) se izračuna tako, da se vsota bruto dodanih vrednosti deli z vsoto števila zaposlenih. Za izračun se upoštevajo uradno objavljeni podatki na spletni strani AJPES JOLP. Pri podjetjih, ki morajo oddati revidirana letna poročila, se za izračun dodane vrednosti na zaposlenega upoštevajo podatki iz revidiranih letnih poročil. Velikost družbe je določena po Zakonu o gospodarskih družbah (ZGD-1): 55. člen.

1. Na podlagi AJPES-u predloženih podatkov iz letnih poročil na poenotenih obrazcih najprej izračunamo dodano vrednost: 


\section{Šifrant za AOP}

Moj Gozdar

\begin{tabular}{|l|l|}
\hline $\begin{array}{l}\text { Za gospodarske družbe, srednje velike } \\
\text { in velike samostojne podjetnike } \\
\text { posameznike ter zadruge }\end{array}$ & $\begin{array}{l}\text { Formula za izračun dodane vrednosti } \\
\text { Bruto dodana vrednost = AOP126 - } \\
\text { AOP128 - AOP148 }\end{array}$ \\
\hline $\begin{array}{l}\text { Za mikro in male samostojne } \\
\text { podjetnike posameznike }\end{array}$ & $\begin{array}{l}\text { Bruto dodana vrednost = AOP050 + } \\
\text { AOP054 - AOP055 + AOP056 + AOP057 } \\
\text {-AOP060 - AOP073 }\end{array}$ \\
\hline
\end{tabular}

2. Izračunano dodano vrednost nato delimo s povprečnim številom zaposlenih na podlagi delovnih ur

\begin{tabular}{|l|l|}
\hline & $\begin{array}{l}\text { Formula za izračun dodane vrednosti } \\
\text { na zaposlenega }\end{array}$ \\
\hline $\begin{array}{l}\text { Za gospodarske družbe, srednje velike } \\
\text { in velike samostojne podjetnike } \\
\text { posameznike ter zadruge }\end{array}$ & $\begin{array}{l}\text { Bruto dodana vrednost na } \\
\text { zaposlenega = dodana vrednost / } \\
\text { AOP188 }\end{array}$ \\
\hline $\begin{array}{l}\text { Za mikro in male samostojne } \\
\text { podjetnike posameznike }\end{array}$ & $\begin{array}{l}\text { Bruto dodana vrednost na } \\
\text { zaposlenega = dodana vrednost / } \\
\text { AOP089 }\end{array}$ \\
\hline
\end{tabular}

\section{Evalvacija indikatorja (točkovanje):}

Ustrezno (3 točke):

- Organizacija izkazuje, da dosega dodano vrednost na zaposlenega, ki je višja od mediane (za dodano vrednost na zaposlenega) v tej dejavnosti, kar je razvidno iz bonitetne ocene.

Delno ustrezno (1,5 točke):

- Organizacija izkazuje neprekinjeno rast bruto dodane vrednosti na zaposlenega v zadnjih treh letih. Organizacija s tem delno ustreza zahtevam izbranega indikatorja in pridobi polovico točk.

\section{Dokazovanje:}

Organizacija predloži skeniran del bonitetne ocene, iz katerega je razvidna višja dodana vrednost na zaposlenega od splošne mediane za podjetja pri tej dejavnosti. 


\section{Literatura}

Dodana vrednost na zaposlenega je 39.463 evrov. 28. 5. 2015. Delo.

https://www.delo.si/gospodarstvo/podjetja/dodana-vrednost-na-zaposlenega-je-39463-evrov.html (30.5. 2019)

Erbežnik, Maruša. 2007. Kvotni sistem in njegovi učinki na zaposlovanje invalidov. Delo in varnost 52 (2): 35-37.

ESA, 2013, European system od accounts - ESA 2010, Dostopno na: https://www.stat.si/dokument/8437/ESA-2010.pdf

Fabčič A. 2010. Vpeljava standarda ISO 14001 v podjetje Toyota Center Ljubljana d.o.o.: diplomsko delo. (Univerza v Ljubljani, Fakulteta za družbene vede). Ljubljana, samozal.: 59 str.

Ferjan M. 1999. Organizacija izobraževanja. Kranj: Moderna organizacija

FinancePRO. 2018. Zakaj vas mora zanimati boniteta lastnega podjetja - in kako jo izboljšati?. https://pro.finance.si/8941206?cctest\& (31. 5. 2019)

Hočevar U. 2016. Uvajanje standarda ISO 9001:2015 v podjetje Šinkovec transport, logistika, d.o.o. magistrsko delo. (Univerza v Mariboru, Fakultetaza logistiko). Celje, samozal.: 69 str.

Horvat P. 2005. Analiza pogostosti vpisov v knjigo pritožb in pohval gostov hotela Piramida - primerjava s hotelom Habakuk. Univerza v Mariboru - Ekonomsko poslovna fakulteta. Maribor, samozaložba

ISO 14001 - Sistem ravnanja z okoljem. ISO portal. http://www.isoportal.si/index.php/standardi/19-sistem-ravnanja-z-okoljem-iso-14001-2004 (8. 3. 2019)

Iso 14001. Iso-standard.si.

http://www.iso-standard.si/iso-14001/ (8. 3. 2019)

Ilič V. 2018. Metodološko pojasnilo - Investicije v osnovna stredstva- Statistični urad RS (zadnjič posodobljeno 19.12.2018). Dostopno na spletu:

https://www.stat.si/StatWeb/File/DocSysFile/8282 (12.8.2018)

Kmetijsko gozdarska zbornica.

https://www.kgzs.si/ (8. 3. 2019) 


\section{Moj Gozdar}

Kmetijsko gozdarska zbornica. Gozd in gozdarstvo.

https://www.gozd-les.com/slovenski-gozdovi/gozdarske-organizacije/kmetijskogozdarska-zbornica (8. 3. 2019)

Kos, Nina. 2010. Kako država spodbuja zaposlovanje invalidov. Pravna praksa 29 (11): $20-21$.

Kotler P. Nancy L. 2005. Corporate social responsibility: Doing the most good for your company. Hoboken, New Jersy: John Wiley and Sons.

http://www.rebelalliance.eu/uploads/9/2/9/2/9292963/kotler_corporate_social_res ponsibility.pdf

Kovač B. 1999. Vrednotenje človeških sposobnosti: Sposobni modeli notranjega podjetništva in razvoj intelektualnega kapitala kot konkurenčna prednost podjetja. Kadri 5 (4): 4-15

Kuntarič M. 2016. Družbena odgovornost podjetja in lokalna skupnost. Univerza v Ljubljani - Fakulteta za družbene vede. Ljubljana, samozaložba

Lipuš A. 2011. Vpliv izobraževanja zaposlenih na uspešnost podjetja: diplomsko delo. Univerza v Ljubljani, Fakulteta za družbene vede. Ljubljana, samozal.: 89 str.

Lukič, N. (2004). Trajnostni razvoj v Evropski uniji (Doctoral dissertation, Univerza v Ljubljani, Fakulteta za družbene vede).

Možina S., Svetilnik I., Jamšek F., Zupan N., Vodovnik Z., 2002. Management kadrovskih virov. Ljubljana: Fakulteta za družbene vede.

Presen, Dominik. 2004. Kvotni sistem. V Pravica do enakih možnosti in enake obravnave - usposabljanje in zaposlovanje invalidov v Evropski uniji in Sloveniji, ur. Cveto Uršič, 103-122. Ljubljana: Inštitut Republike Slovenije za rehabilitacijo, Zveza delovnih invalidov Slovenije.

Presen, Dominik. 2003. Zaposlovanje invalidov in uvedba obveznih kvot. V Zaposlovanje invalidov - med politiko in prakso, ur. Cveto Uršič, 90-95. Ljubljana: Inštitut Republike Slovenije za rehabilitacijo, Zveza delovnih invalidov Slovenije.

Skralovnik D. 2016. Sistem ravnanja z okoljem ISO 14001 v podjetju Kopur d.o.o.: diplomsko delo. (Univerza v Mariboru, Fakulteta za varnostne vede). Ljubljana, samozal.: 47 str. 
Šircelj J. 2006. Standard kakovosti ISO 14001 kot vir konkurenčne prednosti : primer podjetja TIB Transport d.d., Ilirska Bistrica: diplomsko delo. 8Univerza v Ljubljani, Ekonomska fakulteta). Ljubljana, samozal.: 36 str.

Traven S. 1998. Management človeških virov. Ljubljana: Gospodarski vestnik

Triplat M., Krajnc N., Robek R. 2016. Odločevalna matrika za izbor ekološko ustrezne tehnologije pri proizvodnji zelenih sekancev. Acra Silvae et Ligni, 20.

Triplat M., Piškur M., Krajnc N. 2018. Spletni informacijski sistem MojGozdar.si, Gozdarski vestnik, 3, 141-151.

Uršič, Cveto. 1995. Definicije in terminologija. V Zaposlovanje invalidov: primerjava politik, koncepcij in ukrepov, ur. mag. Cveto Uršič in mag. Janez Drobnič, 12-61. Ljubljana: Inštitut Republike Slovenije za rehabilitacijo, Republiški zavod za zaposlovanje.

Urbančič R. In sod., 2010. Poročilo o okolju v Republiki Sloveniji 2009. Gradivo za sprejem na Vladi RS. Ljubljana. Dostopno na spletu: http://nfp-

si.eionet.europa.eu:8980/irc/DownLoad/kjeFA2J2mbG9q46-

FQrBSXEqCp0Dt5m1jY19mt IP6430SLWGyTVT3jrnCXIhZLRZXT8HUksQZS5pHuDc2q2 ruURdFV47ixF/1sjpEf-VPH-UcDhW/POS2009 zdruzeni dokument.pdf (15.4.2019)

Turk I. 2019. Pojmovnik Zveze računovodij, finančnikov in revizorjev Slovenije Naložba v osnovna sredstva - Dostopno na spletu:

https://www.zvezarfr.si/pripomocki/slovar?pojem=naložba\%20v\%20osnovna\%20sre dstva

$(12.8 .2019)$

Zupanc M. 2008. Zagotavljanje kakovosti in okoljska odgovornost javnega sektorja S poudarkom na ISO 9001 in ISO 14001: diplomsko delo. (Univerza v Mariboru, Ekonomsko-poslovna fakulteta). Maribor, samozal.: 68 str.

Žnidaršič Tea. 2015. Je knjiga pohval in pritožb potrebna? Revija Zveze potrošnikov Slovenije. junij, 2015. 
Priloga 1

Preglednica: Seznam dejavnosti po SDK, ki so skladne s področjem gozdno lesnih verig

Šifra

kategorije

Deskriptor

Skladnost dejavnosti

A

\section{KMETIJSTVO IN LOV, GOZDARSTVO, RIBIŠTVO}

A02.100

Gojenje gozdov in druge gozdarske dejavnosti

Sečnja

A02 300

Nabiranje gozdnih dobrin, razen lesa

A02.400

C

C16.100

C16.210

C16.220

C16.230

C16.240

C16.290

C17

C17.110

C17.120

C17.210

C17.220

C17.230

C17.240

C17.290

C28

$\mathrm{C} 28.3$

C28.30

C28.300

$\mathrm{C} 28.4$

$\mathrm{C} 28.49$

C28.490

C31

C31.010

C31.020

C31.030

C31.090

G

G46.120

Storitve za gozdarstvo

\section{PREDELOVALNE DEJAVNOSTI}

Žaganje, skobljanje in impregniranje lesa

Proizvodnja furnirja in plošč na osnovi lesa

Proizvodnja sestavljenega parketa

Stavbno mizarstvo in tesarstvo

Proizvodnja lesene embalaže

Proizvodnja drugih izdelkov iz lesa, plute, slame in protja

\section{Proizvodnja papirja in izdelkov iz papirja}

Proizvodnja vlaknin

Proizvodnja papirja in kartona

Proizvodnja valovitega papirja in kartona ter papirne in kartonske embalaže

Proizvodnja gospodinjskih, higienskih in toaletnih potrebščin iz papirja

Proizvodnja pisarniških potrebščin iz papirja

Proizvodnja tapet

Proizvodnja drugih izdelkov iz papirja in kartona

\section{Proizvodnja drugih strojev in naprav}

Proizvodnja kmetijskih in gozdarskih strojev

Proizvodnja kmetijskih in gozdarskih strojev

Proizvodnja kmetijskih in gozdarskih strojev

Proizvodnja obdelovalnih strojev

Proizvodnja drugih obdelovalnih strojev

Proizvodnja drugih obdelovalnih strojev

\section{Proizvodnja pohištva}

Proizvodnja pohištva za poslovne in prodajne prostore

Proizvodnja kuhinjskega pohištva

Proizvodnja žimnic

Proizvodnja drugega pohištva

\section{TRGOVINA, VZDRŽEVANJE IN POPRAVILA MOTORNIH VOZIL}

Posredništvo pri prodaji goriv, rud, kovin, tehničnih kemikalij
Ustrezno

Ustrezno

Ustrezno

Ustrezno

Ustrezno

Ustrezno

Ustrezno

Ustrezno

Ustrezno

Ustrezno

Ustrezno

Ustrezno

Ustrezno

Ustrezno

Delno ustrezno

Delno ustrezno

Delno ustrezno

Delno ustrezno

Delno ustrezno

Delno ustrezno

Delno ustrezno

Delno ustrezno

Delno ustrezno

Delno ustrezno

Ustrezno

Ustrezno

Delno ustrezno

Delno ustrezno

Delno ustrezno 


\section{F}

F42.110

F43.120

F43.390

F43.990

H

H49.410

M

M71.121

M71.129
Posredništvo pri prodaji lesa in gradbenega materiala

Trgovina na debelo s trdimi, tekočimi in plinastimi gorivi

Trgovina na debelo z lesom, gradbenim materialom in sanitarno opremo

\section{GRADBENIŠTVO}

Gradnja cest

Zemeljska pripravljalna dela

Druga zaključna gradbena dela

Druga specializirana gradbena dela

\section{PROMET IN SKLADIŠČENJE}

Cestni tovorni promet

STROKOVNE, ZNANSTVENE IN TEHNIČNE DEJAVNOSTI

Geofizikalne meritve, kartiranje

Druge inženirske dejavnosti in tehnično svetovanje
Ustrezno

Delno ustrezno

Ustrezno

Ustrezno

Delno ustrezno

Delno ustrezno

Delno ustrezno

Ustrezno

Delno ustrezno

Delno ustrezno 